\title{
MONVMENTA SEPULCRALES EN FORMA DE ALTAR CON PULVINOS DE LOS TERRITORIOS HISPANORROMANOS: REVISIÓN DE MATERIALES Y ESTADO DE LA CUESTIÓN
}

\author{
POR \\ JOSÉ BELTRÁN FORTES \\ Universidad de Sevilla
}

PALABRAS CLAVE: Mausoleos romanos en Hispania. KEY WORDS: Roman Monumental Tombs Spain.

\section{RESUMEN}

Se estudia el desarrollo del tipo de monumentum sepulcral en forma de altar con pulvinos en la Hispania romana, revisando los materiales conocidos, incorporando piezas nuevas y analizando aspectos tales como la tipología, la cronología y las áreas de uso en los territorios peninsulares.

\section{SUMMARY}

I offer the study of the Roman monumenta in altar's form of Hispania, with a lot of unknown pieces (pulvini). Second, I refer aspects as the tipology of the monumenta, the cronology and the areas of use in Hispania.

\section{INTRODUCCIÓN}

En el año 1990 publiqué en esta misma revista un estudio donde analiźaba una serie de materiales arqueológicos, pulvinos y frontones monumentales, procedentes de territorios actuales andaluces (en concreto, Granada, Málaga, Sevilla y, especialmente, Jaén), unos inéditos, otros erróneamente interpretados (Beltrán Fortes, 1990: 183-226). Los pulvinos eran coronamientos de monumenta sepulcrales en forma de altar, y también planteé la posibilidad de que los frontones hubieran podido ocupar el lugar central de ese coronamiento, situado entre los pulvinos, si bien sólo como una de las soluciones posibles. Contamos ahora con síntesis más recientes que, de manera general, han actualizado nuestro conocimiento sobre este modelo de mausoleo romano, especialmente los trabajos de H. von Hesberg (1992: 171-181) o de P. Gros (2001: 392-399) ${ }^{1}$, por lo que

${ }^{1}$ Palian así la justa apreciación de M. Torelli, expresada en 1968, al indicar a propósito de estos monumentos en forma de altar: «...manca ancora un'indagine d'insieme sulle origini tipologiche, sulla diffusione e sulla cronologia di no será necesario incidir de forma extensa sobre los aspectos que atañen a su origen, tipología y áreas de uso. Existen dos desarrollos arquitectónicos básicos en estos tipos de monumenta, uno en que la cámara sepulcral constituye el cuerpo cuadrangular del altar (fig. 1), coronado con dos pulvinos en los laterales (bien cilíndricos, bien con un alargamiento lateral hacia la parte interna), que se desarrolla en Italia desde fines del siglo II a.C. y que llega a alcanzar así grandes dimensiones; y otro, de fecha de inicio más reciente, en que un altar monolítico (con similar variación documentada en la forma de los pulvinos) aparece como coronamiento de la cámara sepulcral, que se situaba, pues, en lo que constituía propiamente el basamento del altar, como testimonian los ejemplos pompeyanos de Naeuoleia Tyche (del 60 d.C.) o de Caluentius Quietus (del 70-79 d.C.) (Kockel, 1983: 90ss.) (fig. 2).

Objetivo básico de mi estudio citado de 1990 era llamar la atención sobre el hecho de que este tipo de monumentum en forma de altar (en los dos desarrollos arquitectónicos citados) había tenido en Hispania un uso mucho más amplio del que se creía hasta entonces, que se había restringido básicamente a un sector reducido del NE peninsular, especialmente en las localidades de Tarraco y, sobre todo, Barcino. No obstante, el carácter singular que se le concedía por esos años a ese conjunto catalán explicaría su ausencia en el estudio de J. Sanmartí (1984) sobre la arquitectura funeraria romana de Cataluña, Aragón y Murcia, a pesar de la exhaustividad y rigor de este análisis. Por entonces, al conjunto catalán podía sumarse sólo alguna otra pieza aislada y asimismo

questa classe» (Torelli, 1968: 32). A esas obras citadas habría que agregar, sobre todo, los estudios de Kockel, 1983, sobre la necrópolis pompeyana de Porta Ercolano, de Eisner, 1986, sobre los mausoleos de Roma, y la obra conjunta, editada por H. von Hesberg y P. Zanker (AA.VV, 1987), sobre las vías funerarias en el mundo romano. Con anterioridad debe destacarse especialmente la síntesis sobre la arquitectura funeraria romana de época altoimperial de H. Gabelmann (1971). 


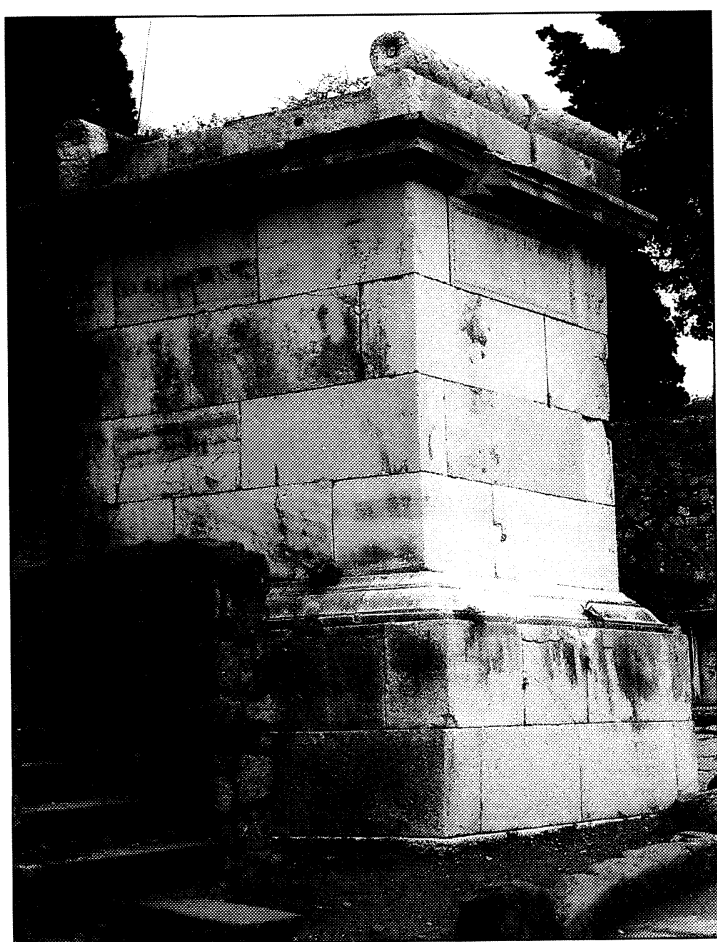

Fig. 1. Mausoleo en forma de altar de Pompeya (necrópolis de Porta Ercolano), donde la cámara sepulcral constituye el cuerpo central del altar, coronado con pulvinos cilíndricos.

poco destacada en la investigación, como la procedente de Segobriga, según referencia de M. Almagro Basch ${ }^{2}$, y con la excepción del breve pero importante capítulo de G. Gamer en su monografía sobre los altares romanos de Hispania, donde se identificaba el tipo y se recogían algunos otros pulvinos monumentales junto a los catalanes, procedentes de Portugal (nueve ejemplares de Idanha-a-Velha), Navarra (ejemplares de Eslava, Gallipienzo y Javier), Mérida (sólo un ejemplar), Cuenca (uno de Segobriga) y Jaén (uno de Ossigi y otros dos de procedencia desconocida del Museo Arqueológico Provincial de Jaén) ${ }^{3}$.

${ }^{2}$ Almagro Basch, 1978: 85 y lám. XIV. Sólo con la fotografía de un pulvino, aunque la serie segobrigense es más abundante, según ha dado a conocer posteriormente Baena del Alcázar, 1993: 147 ss.

${ }^{3}$ Gamer, 1989: 124-126, respectivamente son catalogados como BEB 8 a 16 (lám. 141a-d), NA 8, 20 y 23 (lám. 140ef), BA 53, CU 6 y J 3 a 5 (todos éstos sin lámina). A pesar de la fecha de edición, el trabajo había sido finalizado en la década anterior (1977), con las lógicas consecuencias (cfr. Beltrán Fortes, 1991a: 369-371). Los conjuntos de Mérida, Segobriga y Jaén serán bastante más amplios —-según se dirá en su lugar, más adelante-, y han sido dados a conocer en fecha posterior, respectivamente, por Beltrán Fortes, Baena del Alcázar, 1996a; Baena del Alcázar, 1993; y Beltrán Fortes, 1990.

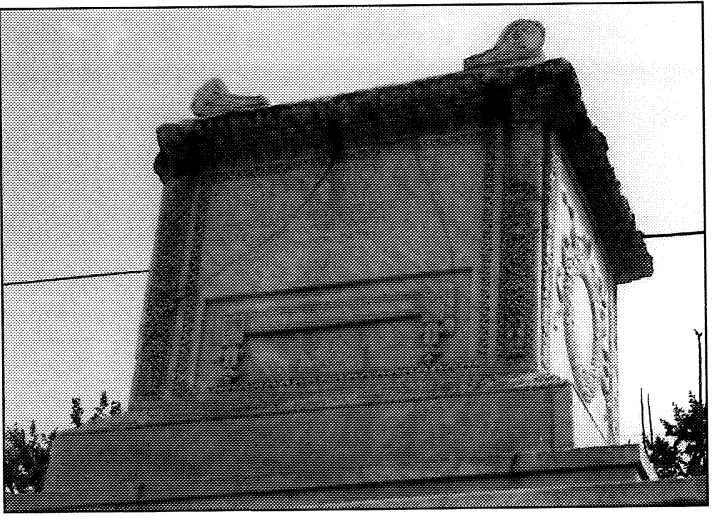

Fig. 2. Fotografía del altar que corona la tumba de C. Caluentius Quietus, en Pompeya (necrópolis de Porta Ercolano), donde los pulvinos presentan un alargamiento lateral hacia la zona interior.

Hemos de concluir que aquel trabajo de hace quince años (Beltrán Fortes, 1999) cumplió su objetivo, o - en todo caso- precedió a una serie importante de nuevas aportaciones que han ido de forma progresiva ampliando el conocimiento sobre el área de expansión en nuestra Península de la arquitectura funeraria y hoy, junto a los monumenta turriformes (abiertos y cerrados), debemos considerar que fue uno de los tipos más frecuentes en la morfología de la arquitectura funeraria hispanorromana en momentos altoimperiales. Ello ha ido de la mano de un renovado interés por los estudios arqueológicos del mundo funerario de la Hispania romana bajo diversos enfoques y planteamientos ${ }^{4}$. En ese contexto, los nuevos materiales conocidos no sólo han ampliado el área de expansión en los territorios hispanos - como se decía-, sino que también aportan datos significativos para un replanteamiento general tanto del uso y morfología exactos de este tipo de monumentum en Hispania, cuanto de la cronología que debe dársele, pero dentro de los inconvenientes aún insalvables que acarrea el hecho de que, en su mayor parte, los ejemplares sean fragmentarios y procedan de descubrimientos casuales o de contextos arqueológicos de reutilización. No pueden lógicamente, pues, contrastarse los diversos conjuntos regionales en aspectos tan fundamentales como el de los rituales sepulcrales asociados a este tipo de tumba monumental. Por el contrario, sí es

${ }^{4}$ Sobresale la espléndida síntesis de von Hesberg, 1993: 159-181. Queda aún inédita Cancela Arellano, 1991, que conocemos sólo por cita. Una visión más reducida del proceso hispanorromano en Beltrán Fortes, 1997: 119-125. Ahora destaca AA.VV. (Vaquerizo Gil, D., ed.), 2002, donde se hacen referencias al tipo de mausoleo en forma de altar (especialmente, Vaquerizo Gil, 2002: 188-193, a partir de los ejemplares cordobeses). 


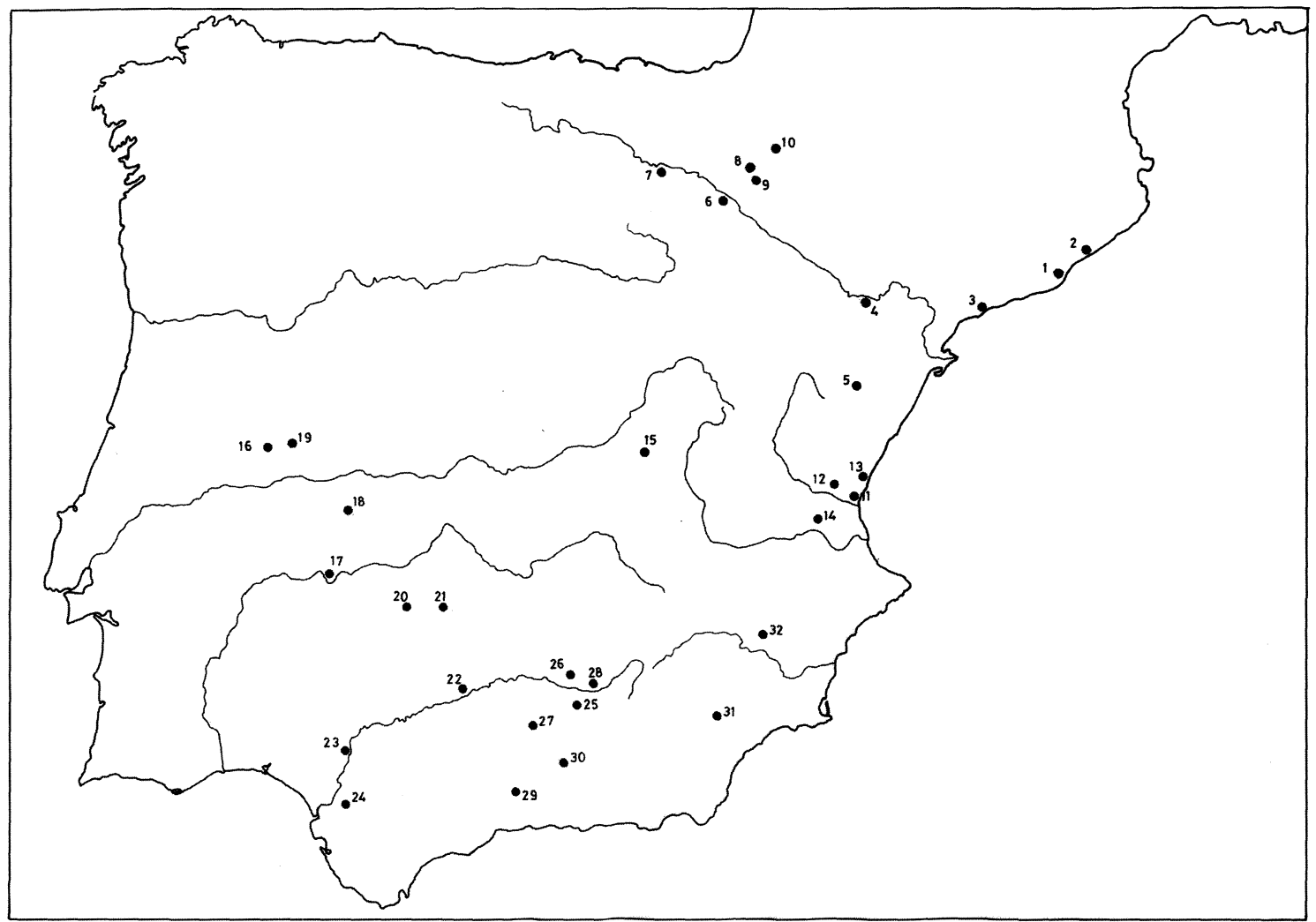

Fig. 3. Mapa de lugares citados en el texto, donde se documentan mausoleos en forma de altar con pulvinos en Hispania. 1. Mataró (Barcelona); 2. Barcelona; 3. Tarragona; 4. Dehesa de los Baños (Chiprana, Zaragoza); 5. Iglesuela del Cid (Teruel); 6. El Sotillo (Alfaro, La Rioja); 7. Varea (La Rioja); 8. Eslava (Navarra); 9. Gallipienzo (Navarra); 10. Javier (Navarra); 11. Valencia; 12. Liria (Valencia); 13. Benifaró de les Valls (Valencia); 14. Hortunas (Requena, Valencia); 15. Saelices (Cuenca); 16. Idahna-a-Velha; 17. Mérida (Badajoz); 18. Trujillo (Cáceres); 19. Coria (Cáceres); 20. Esparragosa de la Serena (Badajoz); 21. Belalcázar (Córdoba); 22. Córdoba; 23. Santiponce (Sevilla); 24. Las Cabezas de San Juan (Sevilla); 25. Cerro Alcalá (Jimena de la Frontera, Jaén); 26. Cazlona (Linares, Jaén); 27. Martos (Jaén); 28. Úbeda la Vieja (Úbeda, Jaén); 29. Cerro del León (Villanueva del Rosario, Málaga); 30. Pinos-Puente (Granada); 31. Vélez-Rubio (Almeria); 32. Ontur (Albacete).

posible testimoniar un significativo aumento de las piezas conocidas, que da pie al intento de establecer un estado general de la cuestión y contestar a una serie de interrogantes que, en parte, ya planteábamos en 1990, aunque muchos de ellos siguen estando sólo planteados como hipótesis por las ausencias citadas de la investigación.

I. LA DOCUMENTACIÓN DE LOS MONUMENTA SEPULCRALES EN FORMA DE ALTAR CON PULVINOS EN LOS TERRITORIOS HISPANOS: REVISIÓN Y NUEVAS PIEZAS (fig. 3)

Es difícil poder dictaminar a ciencia cierta la forma original de un monumentum funerario, y en concreto el desarrollo en altura, si no se han conservado los elementos necesarios. Además, en los momentos tardorrepublicanos el tipo original de mausoleo en forma de altar introdujo las variantes, entre otras (cfr. von Hesberg, 1992: 174ss.), de sustituir en ocasiones los pulvinos por otros tipos de coronamientos, como las acróteras - algo similar, por otro lado, a lo que ocurre en los altares de pequeño formato (Di Stefano Manzella, 1987: 86, fig. 78) - , o incluso una pareja de leones. En el primer caso, podemos aducir, por ejemplo, los monumentos hispanorromanos de la Torre del Breny y de Boades, según la restitución de $\mathrm{H}$. von Hesberg (1993: 167 y fig. $80 \mathrm{c}-\mathrm{d}$ ); en el segundo caso, debe tenerse en cuenta el temprano uso que en la zona meridional de Hispania — sobre todo, en el ámbito del Bajo Guadalquivir- debió tener en momentos tardorrepublicanos el tipo de altar coronado con una pareja de leones, si tenemos en cuenta la nueva valoración de las esculturas de los leones funerarios hispanorromanos que ha llevado a cabo I. Pérez López 
(1999), retrotrayendo la fecha de algunos de ellos al siglo II a.C. ${ }^{5}$.

De todas formas circunscribiremos nuestro análisis estrictamente a aquellos monumentos funerarios coronados por pulvinos y sólo en aquellos casos en que se han conservado, completos o fragmentarios, los pulvinos, obviando casos hipotéticos, más o menos plausibles, dada la enorme variedad morfológica que la arquitectura sepulcral romana de época tardorrepublicana y altoimperial llegó a desarrollar. Así, muchas veces se desconoce el coronamiento de los monumenta, que bien pudieron ser de pulvinos, $o$, incluso, falta el altar ${ }^{6}$.

\section{CATALUÑA}

Sigue siendo el catalán el conjunto más importante de la Península Ibérica, aunque se concentra especialmente en Tarragona y, sobre todo, Barce-

\footnotetext{
${ }^{5}$ Para esta autora, siguiendo los estudios para la Península Itálica de G. A. Mansuelli (1956) y de M. Marini Calvini (1979 y 1980), todos los ejemplares hispanos tendrían esa colocación: «...en forma de parejas custodian un monumen to cúbico, bien de los que se llaman a dado o los concebidos en forma de fachada de planta rectangular que ambos autores denominan a podio...» (Pérez López, 1999: 9), siguiendo el modelo de la tumba de los Stronii en la necrópolis pompeyana de Porta Nocera. No obstante, ya hemos matizado en otro lugar (Beltrán Fortes, 2000a: 435-450, y 2002a: esp. 238-241) nuestra opinión de que, aunque ello es lo más probable para la mayoría de ellos, no siempre debió ocurrir así, y en ocasiones se asocian a otros tipos de monumentos, como los de edícula sobre basamento - según se constata en el caso del mausoleo de fecha augustea que hemos restituido para Salaria (Úbeda) (Beltrán Fortes, Baena del Alcázar, 1996b) - , o en otras soluçiones que no constatamos por ahora. Así, A. Jiménez Díaz (2002: 223) afirma también que muchos de esos leones debieron coronar pilares-estelas, entroncando con la tradición ibérica, aunque debe tenerse en cuenta que ese tipo desaparece en el sureste peninsular a mediados del siglo IV a.C. (Izquierdo Peraile, 2000: 401) y que precisamente no se documentó nunca en los territorios turdetanos, por lo que la estatuaria funeraria de leones en esta zona se vincularía exclusivamente a la presencia romana (Beltrán Fortes, 2000: 435 ss., con bibliografía; cfr., además, Beltrán Fortes, 2002a: 237 ss.).

${ }^{6}$ Es esa la hipótesis, por ejemplo, de M. L. Cancela (1993: 245 ss.) en su interpretación del interior del recinto sepulcral de los Atilii, datándolo a fines del siglo I d.C., frente a la tradicional identificación de un edificio naomorfo (Sanmartí, 1984: 97ss.). P. Gros (2001: 433), si bien acepta la cronología, no hace referencia a la hipótesis del altar central. Para Cancela Arellano (2002: 178s.), de hecho, habría que vincular el fenómeno de los recintos hispanorromanos de muros altos con la presencia de altares en su interior, como asimismo ocurriría con otros ejemplares como el de la ermita de la Consolación de Chiprana (Zaragoza) o el de los Sergii en Saguntum. Es cierto que, en los territorios itálicos, a partir de la época augustea, existe la tendencia de colocar el monumentum en forma de altar en el centro de un recinto delimitado por muros, aunque en los casos hispanos aducidos no queda realmente ningún elemento o referencia de los altares centrales, al menos en el estado actual de la investigación.
}

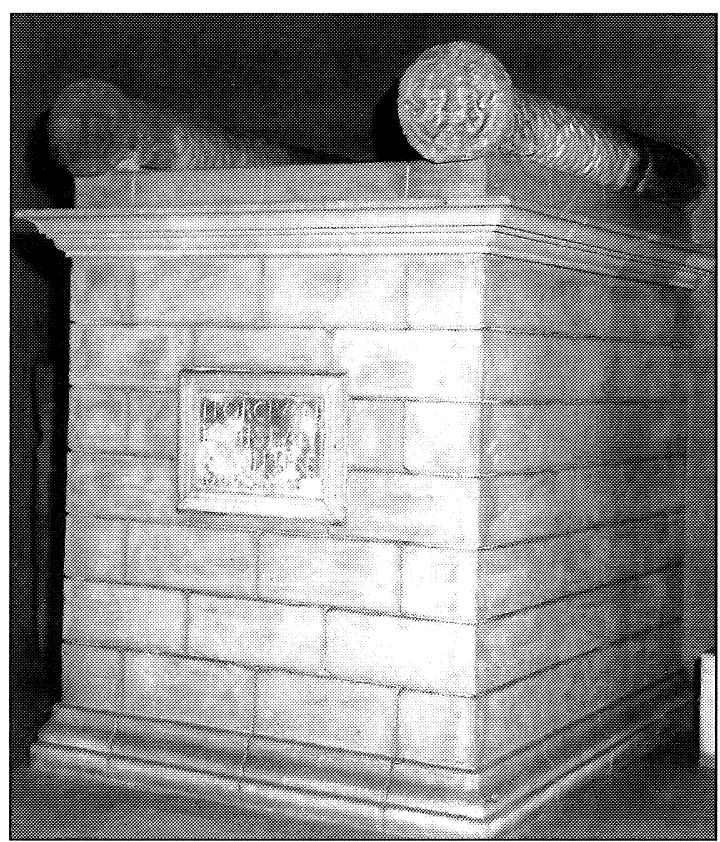

Fig. 4. Antiguo montaje de un mausoleo en forma de altar en el Museo Arqueológico de Barcelona (fotografía: Museo).

lona, como ya fueron referidos en antiguos trabajos, como, por ejemplo, de E. Albertini (1911-1912; esp. $\mathrm{n}^{\text {os }} 170-175$ y 223 ) o J. Puig i Cadafalch (1934: 144ss.; sobre la base de Puig i Cadafalch y otros, 1908: 143-147) ${ }^{7}$, ampliándose la serie de forma destacada con los materiales recuperados del interior de los rellenos de la muralla barcinonense en fechas posteriores. En la segunda mitad del siglo XX destacó especialmente el análisis que llevó a cabo A. Balil (1979) en su breve pero importante estudio de «Los gorgoneia de Barcino», donde encuadra el conjunto barcelonés dentro del marco general de expansión de Italia hacia el valle del Po y la Galia Narbonense; estableció tres tipos básicos de piezas decoradas con gorgoneia ${ }^{8}$ - pero uno no nos interesa ahora ${ }^{9}-$, diferenciando los mausoleos con co-

${ }^{7}$ Sólo se recogen dos de estos pulvinos - llamados «acróteras de monumento fúnebre»- del conjunto de Barcino en la obra de A. García y Bellido (1949: 307, nos 308 y 309), fechados erróneamente en el siglo III d.C. Breve referencia en Taracena, 1947: 56, fig. 38.

${ }^{8}$ Desde el punto de vista del análisis del significado de estas representaciones que decoran mausoleos hispanos en forma de altar, vid., ahora, Jiménez Díaz, 2001. Además, Portabella i Bosch, 1996-1997.

${ }^{9}$ Se trata de un cipo cuadrangular con el gorgoneion en uno de sus frentes, que bien pudo servir como elemento del coronamiento de una edificación funeraria, o más bien como elemento para la delimitación de recintos sepulcrales mediante muros bajos; cfr. Blech, 1993: 335 s., lám. 119b. Sobre su desarrollo en el sur de Hispania, vid. Rodríguez Nei- 


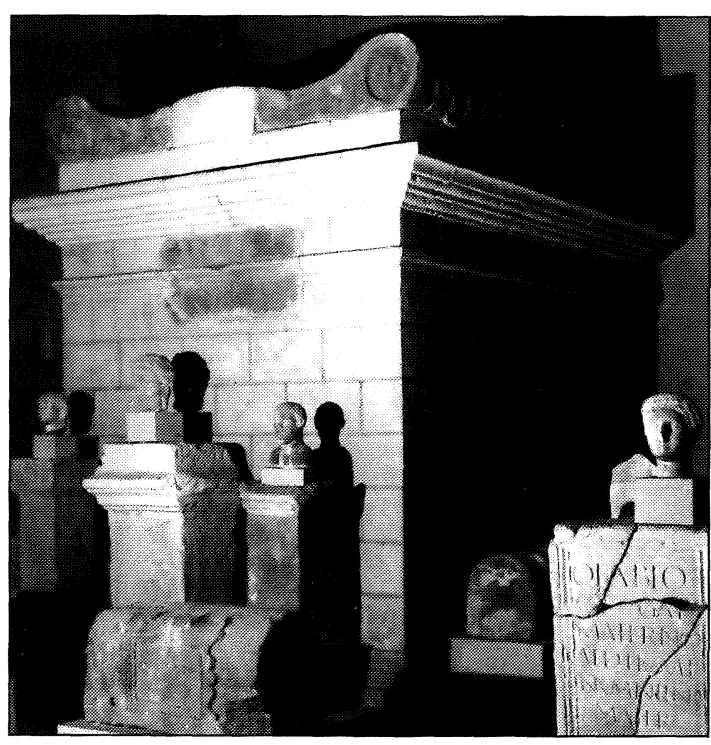

Fig. 5. Otro de los mausoleos en forma de altar reconstruido en el Museo Arqueológico de Barcelona (fotografía: Museo).

ronamiento de pulvinos cilíndricos de frente circular (plutei exentos) y de pulvinos con alargamientos laterales, que siguen, pues, la tipología ya documentada en los territorios itálicos y galos. Aunque la cronología era desacertada («entre fines del siglo I d. de J.C. y los comienzos o el primer tercio, del siglo III d. de J.C.» Balil Illana, 1979: 63), cabe destacar la interpretación general del fenómeno, bastante acertada.

Durante algunos años existieron dos reconstrucciones en el Museo Arquieológico de Barcelona (figs. 4-5) y otra en el de Historia de la Ciudad de Barcelona, que, de forma idealizada pero ilustrativa, reproducían los dos principales tipos de monumenta en forma de altar con coronamiento de pulvinos (unos cilíndricos, otros con alargamientos laterales y frontón central), aunque se encuentran desmontados en la actualidad, posiblemente por las dudas que podrían plantear actualmente aquellas restituciones. Para Tarraco debe citarse la hipótesis, plausible pero indemostrable, indicada por Puig i Cadafalch, de que ciertos basamentos monumentales conservados en el terreno de la denominada «necrópolis cristiana de Tarragona» debieron tener un desarrollo como monumenta en forma de altar (Puig i Cadafalch y otros, 1908: 144 y figs. 174-176) (fig. 6), ya que, en efecto, entre los materiales reutilizados en los enterramientos de época tardía se encuentran fragmentos de

la, 1992: 59 ss.; Vaquerizo Gil, 2002a: 168-206, y 2002b: 168-179; Stylow, 2002: 354.

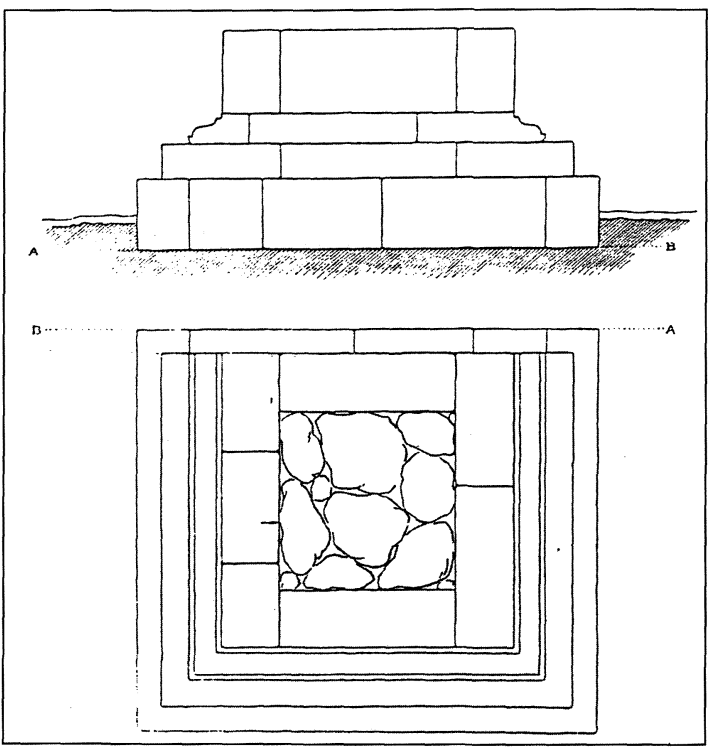

Fig. 6. Dibujo de un basamento que pudo corresponder a un mausoleo en forma de altar con pulvinos, según la hipótesis de Puig i Cadafalch y otros, 1908, fig. 176.

pulvinos cuyas dimensiones serían adecuadas, según testimonian las antiguas fotografías que ilustraban, por ejemplo, las memorias de excavaciones de J. Serra Villaró (1928-1930) (fig. 7). En este caso nos encontraríamos con el tipo en que la cámara sepulcral sirve de cuerpo central del altar y sostiene directamente los pulvinos, pero también para otros autores sería más adecuado su desarrollo como un mausoleo de varios pisos (según von Hesberg, 1993: 159 y fig. 78a), dentro de los problemas generales de restitución a los que nos referimos antes.

Las excavaciones de los últimos decenios no han ampliado de forma cualitativa nuestro conocimiento de este tipo concreto de tumbas monumentales en el sector catalán, si bien sí se ha visto beneficiado de

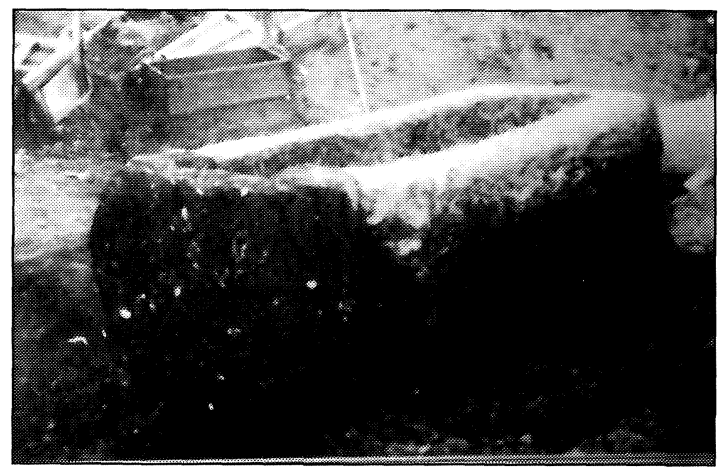

Fig. 7. Fotografía de la excavación de la necrópolis paleocristiana de Tarragona, donde se aprecia la reutilización de parte de un pulvino en la cabecera de un sarcófago, según Serra Villaró, 1928-1930. 


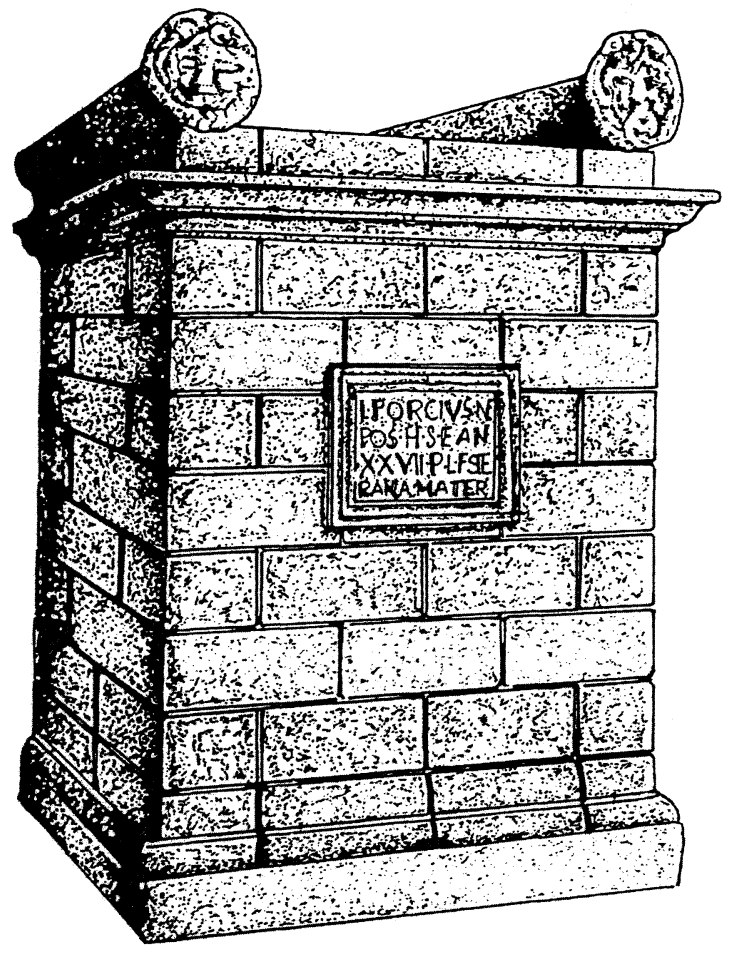

Fig. 8. Restitución de un altar de Barcino, según Portabella i Bosch, 1996-1997, fig. 8.

un mejor conocimiento general sobre el mundo funerario romano, en cuyo contexto se insertan ${ }^{10}$. A lo sumo, alguna nueva pieza amplió el ámbito de expansión de este tipo hacia el norte, en concreto hasta Mataró, a partir de un pulvino con alargamiento lateral y elaborado en mármol - frente al uso generalizado de las piedras locales no marmóreas en todo el resto de la serie catalana-, que se decora con gorgoneion en el frente y que apareció en 1976 en el «Camí del Mitg», en Mataró, en el marco de la via Augusta entre Iluro y Baetulo, correspondiendo al ager de la primera ciudad ${ }^{11}$. G. Gamer (1989) catalogó de la serie de pulvinos catalanes sólo un ejemplar en el Museo Paleocristiano de Tarragona (Gamer, 1989: T 80, lám. 140c-d), aunque refiere los recogidos por J. Puig i Cadafalch (1934: 144), y una veintena procedente de Barcelona (Gamer, 1989: B 18 a 28 y 44 a 46, láms. 137a-b, 138a-h,

\footnotetext{
${ }^{10}$ Cfr., especialmente, Rodá de Llanza, 2000, 173-196.

${ }^{11}$ Balil Illana, 1988, 31, nº 169, lám. XIII, que indicaba que no se conocen otros ejemplares en zonas más al norte de la Tarraconense, lo que coincide con la menor presencia de esta serie de monumentos en los territorios vecinos de la Narbonense (según Rodá de Llanza, 2000: 178), a diferencia de la enorme cantidad de bloques con friso dórico (Joulia, 1988). La pieza manresana es estudiada ahora por Bosch de Doria, 1998.
}

139a-c y 140a-b), incluyendo la pieza antes citada de Mataró (Gamer, 1989: B 57, lám. 138i). Más recientemente algunos ejemplares catalanes han sido vueltos a estudiar (Portabella i Bosch, 1996-1997) (fig. 8) o incluidos en estudios más generales (p.e., Paoletti, 1988: 345ss.; Blech, 1993: 334s., láms. 118s.).

\section{El VAlle del EbRo: ARAGÓN, LA Rioja Y NAVARRA}

Conocemos tres fragmentos de pulvinos aparecidos en la fase tardorromana de una uilla excavada en Dehesa de los Baños (Chiprana, Zaragoza), dados a conocer por M. L. Cancela ${ }^{12}$. Aunque no se daban las dimensiones de las tres piezas, sí se fotografió una de ellas, que medía aproximadamente $1,08 \mathrm{~m}$ de longitud y algo menos de $0,30 \mathrm{~m}$. de diámetro, con la típica decoración de hojas imbricadas y un balteus de $0,38 \mathrm{~m}$. de largo, enmarcado por un listel simple y decorado efectivamente con el nudo hercúleo. Si consideramos que para la reconstrucción de la pieza completa el espacio que falta en uno de los extremos sea similar al conservado en el otro sentido, ocupando el balteus el centro exacto del pulvino, éste pudo medir $1,58 \mathrm{~m}$, pero no sabemos si, en efecto, el tramo mayor conservado corresponde al extremo final, por lo que también pudo ser de mayores dimensiones. Posiblemente fueron parte de sendos pulvinos que coronaron el edificio sepulcral documentado en el yacimiento y datado en los inicios del siglo I d.C. ${ }^{13}$.

En un ámbito cercano de la vecina provincia de Teruel, F. Arasa reconoció perfectamente y estudió los restos arquitectónicos romanos reaprovechados en la construcción de la ermita de la Virgen del Cid, en Iglesuela del Cid, interpretándolos como perte-

12 1993: 252, lám. III, 2, indicando que se trataba «...de tres piezas que aparentaban ser semicolumnas, empleadas como pies derechos en un impluvium de la parte central del edificio. Las decoraciones de hojas de laurel imbricadas junto con el nudo de Hércules que aparece en los extremos permite afirmar con seguridad que se trata de un pulvinus perteneciente a un monumento funerario de tipo ara. Ello coincidia con la presencia de dos inscripciones funerarias, igualmente reutilizadas como material de construcción, una de ellas completa, inscrita en tabula ansata, en la que Valeria Restituta aparece como dedicante a L. Porcio S(evero). La cronología... [del monumento en forma de altar] la situamos en el siglo I, no más allá de época flavia».

${ }^{13}$ Según Martín-Bueno, 1976: 149 ss.; asimismo se encontraban reutilizados dos bloques epigráficos, con la cartela en forma de tabula ansata, que documentaba un mausoleo familiar de dos Porcii y una Valeria Restituta, aunque era datado a fines del siglo I d.C. (Fatás, Martín-Bueno, 1977a: 22, $n^{\circ} 17$ ) (Cfr. nota anterior). 
necientes a una construcción funeraria turriforme de la que se conservaba, in situ, parte de la estructura de la edificación hasta una altura de varios metros, con el podio y la cornisa moldurados (Arasa, 1987: 141 ss.). Coincidí con M. L. Cancela en la hipótesis de que el mausoleo turolense original era un altar con pulvinos, del tipo con alargamientos laterales de acusado perfil cóncavo y en el frente un relieve de rosetas, reconocible entre los materiales empotrados en el edificio de la ermita (Beltrán Fortes, 1990: 198); pero como indica esa autora el panorama es más complejo, ya que aunque el ejemplar que nos interesa «...queda muy bien perfilado como un ara monumental de unos $4 \mathrm{~m}$. de longitud por $2 \mathrm{~m}$. de anchura y por unos $4 \mathrm{~m}$. de altura. Los pulvina se colocarían en los lados cortos de este monumento con el remate visible en sus extremos de voluta con una roseta exapétala» (Cancela Ramírez, 1993: 251) ${ }^{14}$, otros elementos arquitectónicos reaprovechados en la ermita formaron parte de otra edificación sepulcral que habría sido desmontada en un entorno próximo, seguramente de tipo turriforme o templiforme, con pilastras de capiteles corintizantes en las esquinas ${ }^{15}$.

Podemos identificar además nuevos ejemplares de pulvinos en los territorios de La Rioja, que sirven para jalonar la vía de penetración hacia el interior del valle del Ebro en función de la presencia romana. En primer lugar, entre los restos arquitectónicos aparecidos en El Sotillo, en Alfaro, en las inmediaciones de la ciudad romana de Graccurris, de la que el yacimiento se sitúa a menos de un kilómetro (Hernández Vera y otros, 1999). Fueron considerados como parte de un pequeño templo, pero parece plausible pensar que nos encontraríamos también con los restos de un mausoleo en forma de altar, como ya ha corregido D. Vaquerizo (2001a: 147, nota 37 ; y 2002: 190, nota 94), dado que falta todo elemento de la hipotética cubierta y, por el contrario, sí contamos con un fragmento de pulvino con la típica decoración de hojas imbricadas y nervadura

\footnotetext{
${ }^{14}$ Entre los materiales epigráficos reutilizados en la ermita se reconocen bloques con cuatro inscripciones funerarias dedicadas a individuos de la gens Domitia (Navarro Caballero, 1994: 66-68 y 113 ss., $\mathrm{n}^{\text {os }} 15-17$, con la bibliografía anterior).

${ }^{15}$ Queda la duda de si un friso decorado con el esquema decorativo en relieve de dos delfines en los extremos y una crátera en el centro, flanqueada por dos páteras (según Arasa) o kylikes (según Cancela), pudo pertenecer o no al monumentum en forma de altar, ya que es plausible en función de los paralelos conservados; sobre todo si los comparamos con los coronamientos de altares de Valencia, que citaremos luego, a pesar de las diferencias formales y de que en los ejemplares valencianos decoraban los frontones situados entre los frentes de los pulvinos.
}

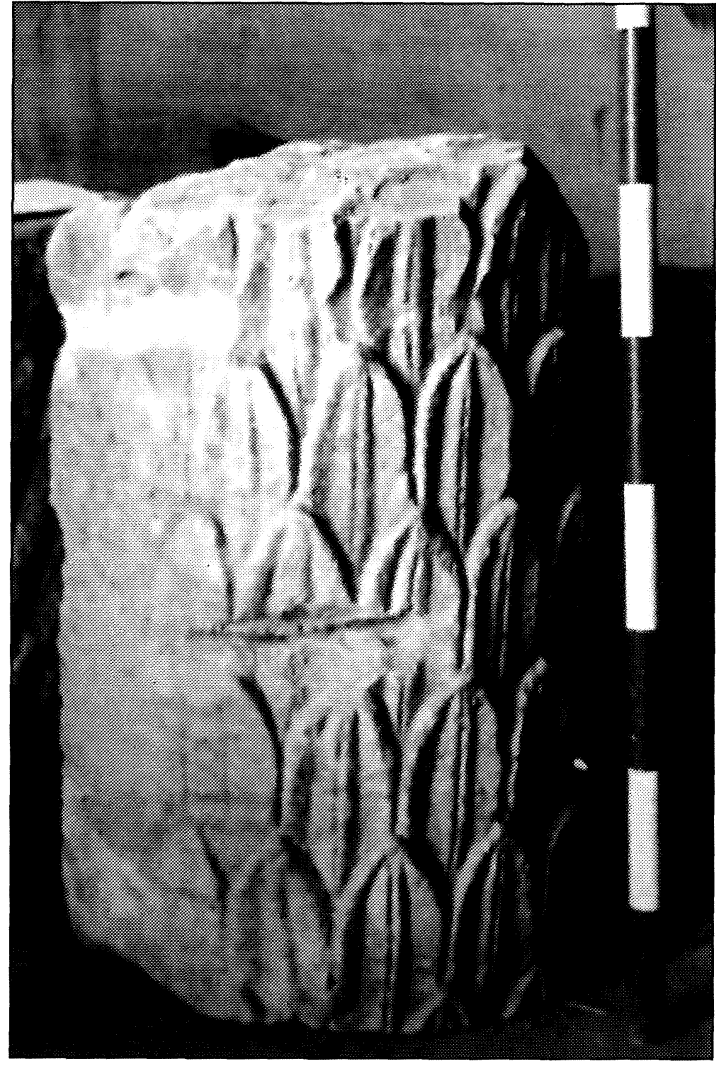

Fig. 9. Fragmento de pulvino de El Sotillo (Alfaro, La Rioja), en el entorno de Graccurris, según Hernández Vera y otros, 1999, lám. 14.

central ${ }^{16}$ (fig. 9). En este caso es importante que conozcamos el contexto arqueológico a partir de la excavación realizada; el lugar exacto se sitúa en la margen izquierda del río Alhama (en cuyo cauce se localizaron restos una presa romana elaborada con sillares), al pie de una uia (en cuyo contexto apareció asimismo un miliario de época de Augusto) y muy cerca de la «necrópolis de la Azucarera», una de las necrópolis urbanas de Graccurris. Como fruto de un expolio todavía en época romana altoimperial - con anterioridad a finales del siglo II d.C.sólo se recuperaron de forma descontextualizada diversos bloques pétreos, pero que permitieron la re-

${ }^{16}$ Hernández Vera y otros, 1999: 253 s., lám. 14, erróneamente interpretado como un tambor de columna con decoración vegetal; tiene medio metro de diámetro y, en lo conservado, $0,64 \mathrm{~m}$ de longitud, sin apreciarse ninguno de los frentes de la pieza, ni restos del balteus, por lo que no se puede establecer la longitud exacta. Se indicaba la existencia de una mortaja que, en efecto, serviría para facilitar su encaje con otra pieza del pulvino; la ausencia del relieve en una parte de la superficie correspondería a la zona de apoyo en la parte alta del mausoleo. 


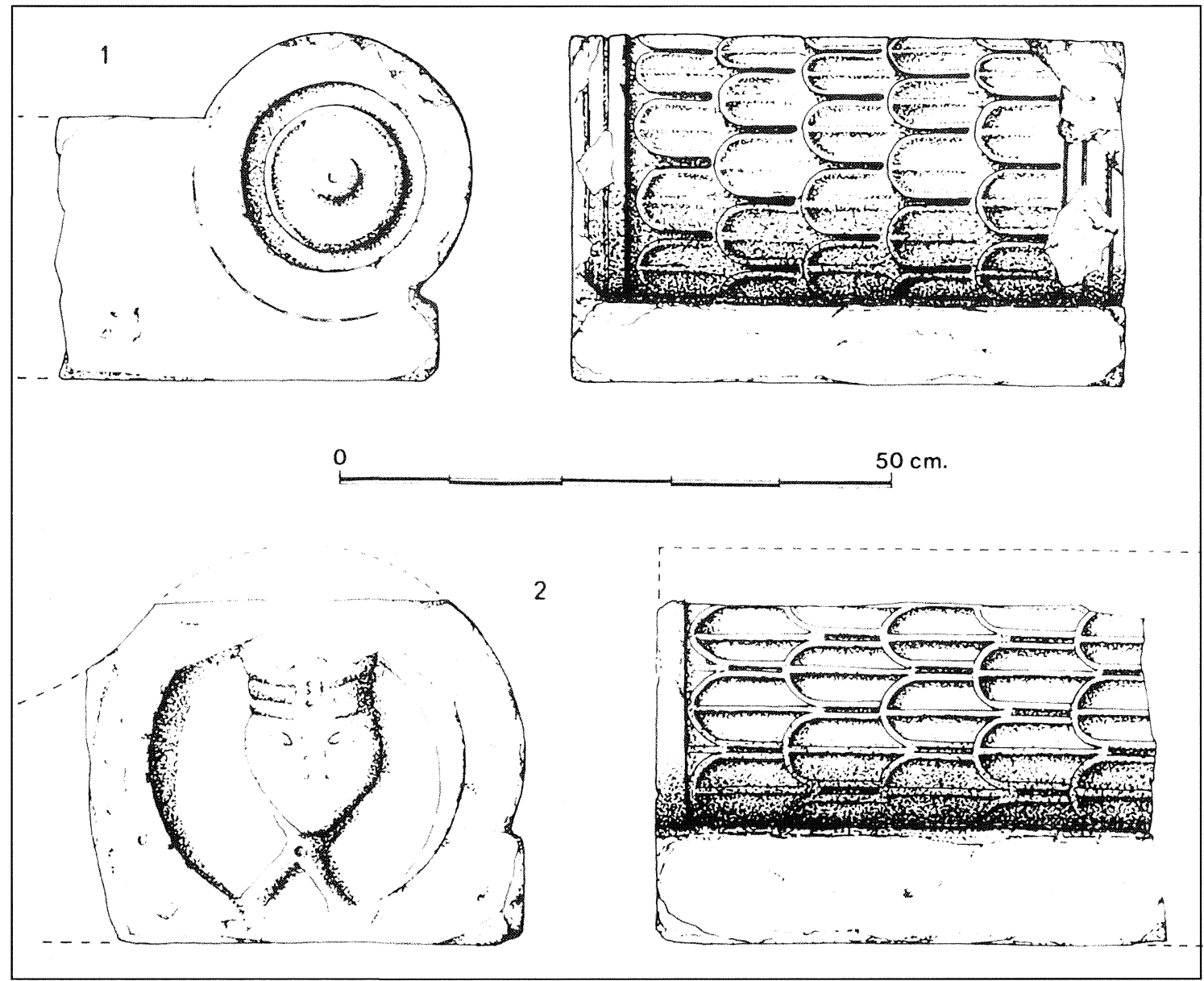

Fig. 10. Dibujos de dos fragmentos de pulvinos de Vareia (Varea, La Rioja), según Espinosa, 1996, fig. 5.

construcción de dos estructuras arquitectónicas: por un lado, un estanque o ninfeo, construido mediante sillares y con un posible desagüe al río (Hernández Vera y otros, 1999: 250-253), y, por otro lado, otras piezas descontextualizadas (fragmentos del podio moldurado, un capitel corintio de pilastra, sillares lisos y decorados con fustes de pilastra...) consideradas como parte de un templete de culto a las ninfas, de planta rectangular, elevado sobre un podio y con pilastras corintias (Hernández Vera y otros, 1999: 249, fig. 6), pero que realmente debió ser como se dijo - un mausoleo en forma de altar con pulvinos ${ }^{17}$. Sí es importante la datación de todo el conjunto en época augustea (Hernández Vera y

\footnotetext{
${ }^{17} \mathrm{El}$ que este tipo de mausoleos en forma de altar coloque pilastras en las esquinas está también documentado, como ocurre para territorio hispano en el mausoleo de La Calerilla (Requena, Valencia), que mencionamos a continuación. Para otros ejemplos extrahispanos, p.e., von Hesberg, 1992: 173, fig. 108 .
}

otros, 1999: 260), lo que establece un importante hito cronológico para la introducción de este tipo de monumentos en el ámbito interior del valle del Ebro. El resultado que proponemos se adecua bien a una construcción funeraria en forma de altar, en el marco de una necrópolis urbana y situada al borde de una uia, como es habitual.

También para el territorio riojano ha dado a conocer U. Espinosa (1996: 437-439) dos fragmentos de pulvinos de la ciudad de Vareia (Varea), ambos elaborados en arenisca local (fig. 10). Amén de cierta diversidad de tamaño, presentan significativas diferencias formales que justifican que hayan sido interpretados como de dos monumentos diferentes (Espinosa, 1996: 437s., figs. 5.1 y 6.1) (fig. 11) ${ }^{18}$.

${ }^{18}$ La decoración de hojas imbricadas en la superficie del pulvino es bastante similar y ambos tendrían alargamientos laterales, pero también los dos los presentan fracturados. Un fragmento mide de $0,305 \mathrm{~m}$ de altura, $0,37 \mathrm{~m}$. de ancho y $0,50 \mathrm{~m}$ de profundidad, presenta un alargamiento de perfil 


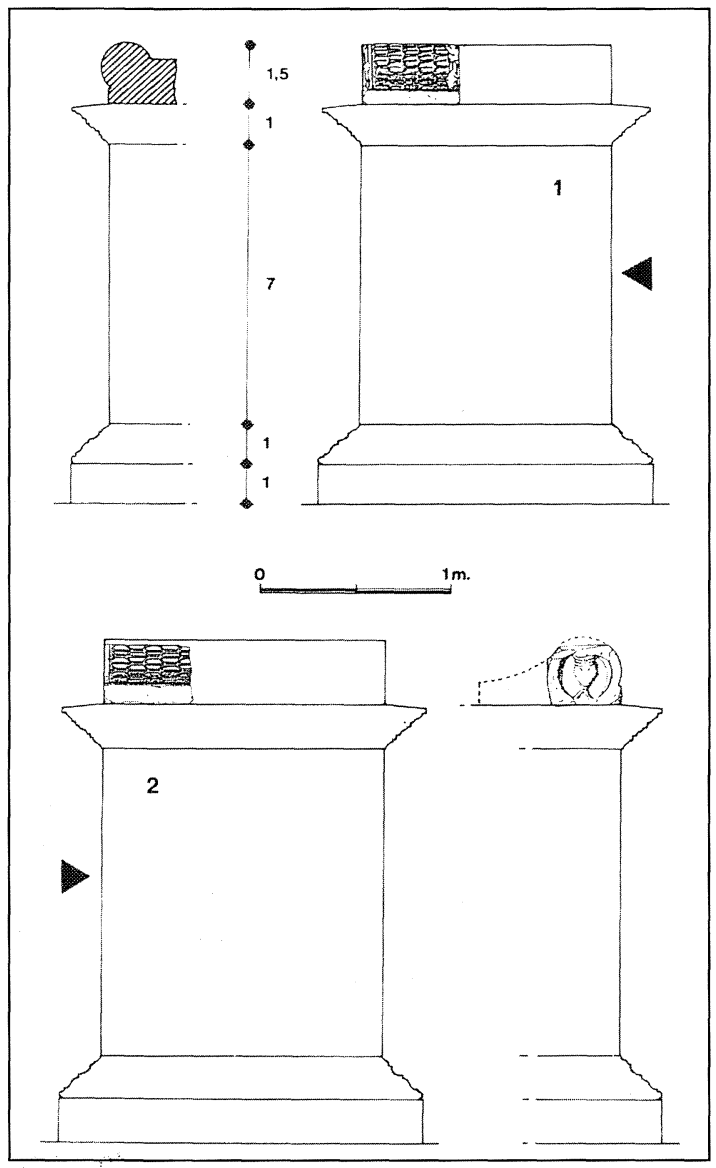

Fig. 11. Dibujos reconstructivos de los mausoleos en forma de altar de Vareia (Varea, Logroño), según Espinosa, 1996, fig. 6.

Los frentes de ambos pulvinos se decoran respectivamente con una patera y con una cabeza de difícil identificación ${ }^{19}$. No existen argumentos para establecer la cronología exacta de los dos mónumentos vareyenses (fig. 11); su editor consideraba una datación entre la segunda mitad del siglo I d.C. y el s. II d.C. en función de la cronología tradicional asignada a este tipo de monumentum en la Península Ibéri$\mathrm{ca}, \mathrm{y}$, en todo caso, posteriores a otro edificio turriforme de la propia Vareia, al que pertenecería un

superior recto. El segundo pulvino, que conserva las dimensiones máximas de $0,295 \mathrm{~m}$ de altura, $0,39 \mathrm{~m}$. de anchura y $0,465 \mathrm{~m}$. de profundidad, aparece fracturado además en la parte superior del pulvino, mientras que en este caso el alargamiento lateral presenta un perfil de tendencia curva (Espinosa, 1996: 437s., figs. 5.2, 6.2 y 17.2).

${ }^{19} \mathrm{Al}$ no aportarse fotografías, hemos de seguir sólo el dibujo y descripción de su editor: «...cabeza con pómulos salientes, barbilla apuntada, ojos oblicuos y rasgados. Viste gorro cilíndrico y elevado con dos cintas horizontales; al cuello parece portar pañuelo del que cuelgan los extremos» (Espinosa, 1996: 437). fragmento de friso dórico (con dos triglifos que enmarcan una metopa decorada con una cabeza de toro), que habría que datar en la primera mitad del siglo I d.C. (Espinosa, 1996: 439). Sin embargo, no creemos justificada esa diferencia cronológica por los argumentos expuestos, ya que ahora se acepta que el tipo en forma de altar se emplea desde al menos la época augustea y que, incluso, algunos autores habían considerado muy probable que los frisos dóricos barceloneses se asociaran también a coronamientos de pulvinos (Balil Illana, 1979; Rodá de Llanza, 2000). Este enclave urbano de Vareia nunca llegó a alcanzar el rango de municipio, pero estuvo acantonada en él una vexilatio de la legio IV Macedónica desde época de Augusto hasta la de Calígula o principios del reinado de Claudio (Espinosa, 1996: 433), lo que podría justificar la existencia de estos monumenta de modelo romano-itálico en aquellos momentos.

En los cercanos territorios de Navarra sólo podemos volver a citar los materiales ya analizados por G. Gamer (1974: 242ss., y 1989: 37s. y 126), que proceden de un sector muy próximo a la provincia de Zaragoza. Así, un fragmento de pulvino procede de Eslava y fue elaborado en piedra local (fig. 12), conservándose las dimensiones máximas de $0,38 \mathrm{~m}$ de altura, $0,45 \mathrm{~m}$ de anchura y $0,59 \mathrm{~m}$ de longitud, siendo la altura del zócalo sobre el que asienta el pulvino de 0,13 m (Gamer, 1974: 242, nº 29, lám. 57b; y 1989: NA 8, con bibliografía anterior). La segunda pieza procede de Gallipienzo, asimismo ejecutada en piedra local y que conserva las dimensiones máximas de $0,25 \mathrm{~m} \times$ 0,43m × 0,84m (Gamer, 1974: 243, no 41, lám. 57a; Idem, 1989: NA 20, con bibliografía anterior). Finalmente, debemos destacar un pulvino completo del entorno de Javier, que se apoya sobre un zócalo y tiene un alargamiento lateral; está elaborado en piedra local, con las siguientes dimensiones máximas: $0,45 \mathrm{~m} \times 0,46 \mathrm{~m} \times 1,70 \mathrm{~m}$, siendo la altura del zócalo de 0,15 m (Gamer, 1974: 244, $\mathrm{n}^{\circ}$ 44, lám. 57c; Idem, 1989: NA 23, lám. 140 e-f , con bibliografía anterior). En este caso el cuerpo del pulvino aparece decorado en la cara externa con largas hojas de acanto en las que se ha em-

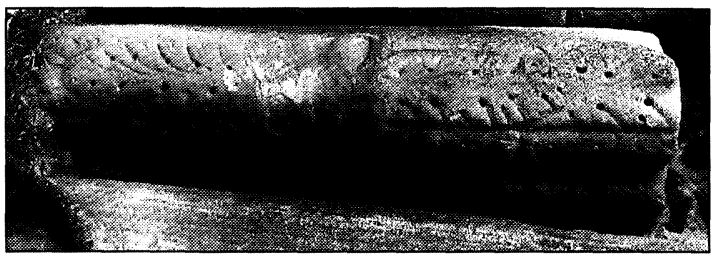

Fig. 12. Pulvino de Eslava (Navarra), según Gamer, 1974, lám. $57 \mathrm{~b}$. 
pleado con profusión el trépano, mientras que en la cara interna, que no quedaba a la vista, esa decoración se ha visto sustituida por hojas imbricadas de perfil redondeado, con muy poco relieve sobre la superficie de la piedra. Es posible, como argumenta G. Gamer (1989: 38s.), que estos ejemplares derivaran de los mausoleos de la costa tarraconense, aunque ya se testimonian otros ejemplos aragoneses intermedios.

\section{LEVANTE Y SURESTE}

En el contexto del Levante español han sido aportaciones recientes de J. L. Jiménez Salvador (1995 y 2002) las que han constatado la existencia de monumentos en forma de altar en el ámbito próximo a Valencia. Uno de estos coronamientos, fragmentado, que procede de la propia Valentia (Valencia) ${ }^{20}$ (fig. 13), corresponde a la necrópolis oriental de la ciudad, de donde proceden «... los monumentos funerarios de mayor prestigio» (Jiménez Salvador, 2002: 190 y fig. 6). Sólo se ha delimitado en el bloque el pulvino cilíndrico (de sólo 0,185 m de diámetro) y liso, sin balteus, pero decorado en el frente con una roseta de seis pétalos y botón central, y el frente del frontón, de perfil cóncavo-convexo contrapuesto, que se adecua a los cuerpos de dos delfines también contrapuestos, bajo cuyas cabezas se coloca una corona anudada con vittae.

En la misma provincia valenciana, podemos mencionar otro coronamiento de Lliria dado a conocer por Jiménez Salvador (1995: 213s., láms. 3-5) ${ }^{21}$, que, aunque morfológicamente diverso y de dimensiones menores al anterior, es similar en la decoración del frente, con rosetas de seis pétalos en el frente de los pulvinos y dos delfines, afrontados esta vez por las colas y flanqueando un tridente, decorando el frontón, en este caso de forma triangular. Finalmente de la también valenciana localidad de Benifaró de les Valls procede otro coronamiento de altar, donde el frontón remonta por encima de los pulvinos (con rosetas hexapétalas en su frente), pero se decora también con dos delfines contrapuestos

\footnotetext{
${ }^{20}$ Elaborado en caliza local, tiene unas dimensiones máximas de $0,36 \mathrm{~m}$ de altura, $0,685 \mathrm{~m}$ de anchura conservada pero que correspondería a $1,05 \mathrm{~m}$. originalmente, y un grosor de $1,05 \mathrm{~m}$, por lo que sería un bloque cuadrado, con una mortaja en el centro de la cara superior para facilitar su desplazamiento, como indica Jiménez Salvador, 1995: 211ss., fig. 2 y láms. 1-2.

21 Tiene unas dimensiones de $0,29 \mathrm{~m}$ de altura, $0,59 \mathrm{~m}$ de altura y $0,43 \mathrm{~m}$ de grosor, y asimismo está ejecutada en caliza local. Importantes edificios sepulcrales han aparecido en Lliria, que han sido restituidos y estudiados por Aranegui Gascó, 1995.
}

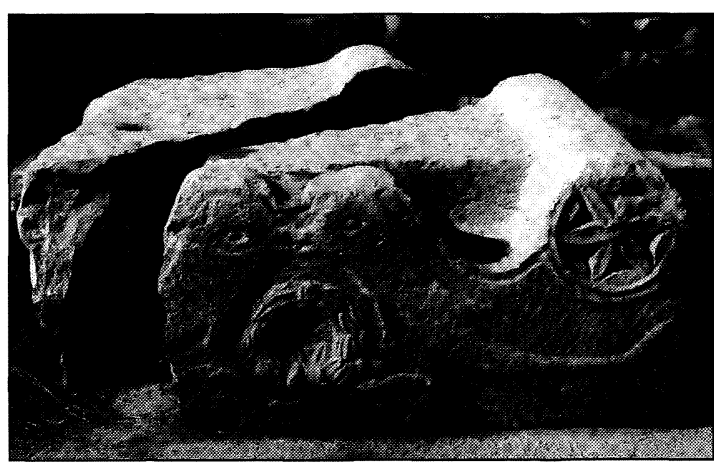

Fig. 13. Coronamiento monolítico de altar funerario de $\mathrm{Va}$ lentia (Valencia), según Jiménez Salvador, 1995, fig. 2.

por las colas y -en esta ocasión- con un jarro de dos asas en el centro del espacio libre (Jiménez Salvador, 1995: 214 ss., láms. 6-10) ${ }^{22}$.

Las tres piezas reflejan una tipología común, sobre todo en el esquema ornamental, y una morfología diversa de las analizadas hasta ahora ${ }^{23}$, quizás explicable porque se trataría de altares monolíticos de menores dimensiones situados por encima de la cámara sepulcral, sobre todo en los dos primeros ejemplares. A ello apuntan, en efecto, las menores dimensiones de los pulvinos y el hecho de que todo el coronamiento se elabore en un mismo bloque ${ }^{24}$. Jiménez Salvador (1995: 216-219) también destacó la singularidad de los motivos decorativos, en especial de la pareja de delfines (que remiten a los testimoniados entre los relieves de la ermita de la Virgen del Cid, en Iglesuela del Cid), y les otorgó una fe-

${ }^{22}$ Está elaborado también en caliza, tiene unas dimensiones de $0,54 \mathrm{~m}$ de altura, $0,79 \mathrm{~m}$ de anchura y $0,22 \mathrm{~m}$ de grosor. Es posible que nos encontremos en este caso, por tanto, con una estela que reproduce en su frente el esquema de los altares típicos de esta zona valenciana, dado el pequeño grosor de la pieza.

${ }^{23}$ Por dimensiones $(0,30 \mathrm{~m}$ de altura, $0,73 \mathrm{~m}$ de anchura $\mathrm{y}$ $0,65 \mathrm{~m}$ de grosor), estructura (como frontón elaborado en un bloque monolítico) y el uso de caliza local, podríamos traer a colación un coronamiento de El Tossal de l'Assut, conservado hoy en el Museo Provincial de Bellas Artes de Castellón de la Plana, que presenta pulvinos cilíndricos, con dos bustos masculinos esculpidos en sus frentes, y otra figura completa con túnica larga en el frontón triangular, que aparece flanqueado por la inscripción $D($ is $) M($ anibus $)$, datado por Arasa (2000: 154ss., lám. II, 2) en los siglos II-III d.C., aunque seguramente sea ésta una cronología algo avanzada.

${ }^{24}$ No obstante, también podrían interpretarse como coronamientos de grandes arae ossuariae (Di Stefano Manzella, 1987: 86), que se elaboran en un bloque aparte, para poder colocar la urna en el interior del cuerpo del altar, como los coronamientos conocidos especialmente para la zona lusitana de los actuales Estremoz y el sur portugués (Gamer, 1989: 128ss. y láms. 142s.), mientras que para la Baetica seguramente tenemos una pieza similar en el coronamiento monumental de Solia, en El Guijo (Córdoba) (Stylow, 1986: 252s., n 9, lám. 31c; Beltrán Fortes, 1988: 135, n 64). 
cha altoimperial, que concreta en el siglo II d.C., al menos para el ejemplar de Valentia.

Más acorde con la tipología donde la cámara sepulcral forma el cuerpo del monumental altar es el edificio funerario de La Calerilla, en Hortunas, en el término municipal de Requena, en un lugar situado más al interior de la provincia de Valencia que los tres puntos considerados antes. Además, frente a la gran mayoría de las piezas que venimos viendo, se conoció en el curso de una excavación arqueológica; si bien el mausoleo estaba violado y desmontado desde antiguo, ofrece un conjunto importante de fragmentos que han permitido a su excavadora una restitución fiable, al menos en sus líneas básicas (Martínez Valle, 1995). El yacimiento corresponde a una necrópolis rural en la que se documentó in situ sólo parte del basamento del mausoleo, junto a otros fragmentos arquitectónicos desmontados —a los que nos referiremos ahora-, así como varias incineraciones en forma de bustum; éstas, que son datadas en torno a la época flavia, fueron ejecutadas dentro de un recinto delimitado por un muro y ordenadas con respecto al mausoleo (Martínez Valle, 1995: 278). Pero sobresale especialmente la reconstrucción del mausoleo en forma de altar coronado por pulvinos que lleva a cabo esta autora, ya que se cuenta con el basamento de base cuadrangular (con dimensiones de $5,15 \mathrm{~m}$ en la fachada NE y unos $3,75 \mathrm{~m}$ en la SE), restos de los dos escalones del zócalo elaborado mediante sillares, sobre el que se elevaría la base moldurada (con un caveto entre dos cuartos de círculos, los tres separados por pequeños biseles), el capitel corintio que coronaría las pilastras de esquina, un bloque del friso epigráfico, fragmentos de un friso de ovas y dardos y de la cornisa, y, finalmente, un fragmento del cuerpo y frente de un pulvino que coronaría el conjunto y del que se supone un diámetro de $0,45 \mathrm{~m}$. Todo el desarrollo arquitectónico se elaboró en calizas locales y destaca, en este caso, la existencia de parte del epígrafe asociado al monumentum, que corresponde al bloque de la esquina izquierda del frente, con un erote sosteniendo la cartela, enmarcada a su vez a cada lado por dos pares de volutas contrapuestas. El epígrafe, en letras capitales cuadradas y dispuesto en tres líneas, dice: Domitia / L(ucii). f(ilia). Iusta / sibi. et. // [- $]^{25}$. Como

${ }^{25}$ Ya había sido dado a conocer en Martínez Valle, 1991. Apunta esta autora una posible relación de los Domitii de Requena con los citados en los epígrafes de La Iglesuela del Cid, analizados supra, lo que justificaría en parte la presencia de este mausoleo en este sector del interior levantino (Martínez Valle, 1995: 276). Ello podría explicar también la disimilitud tipológica y cronológica entre este ejemplar y el resto de los documentados en ámbitos más costeros de este sector levantino, que vimos con anterioridad.

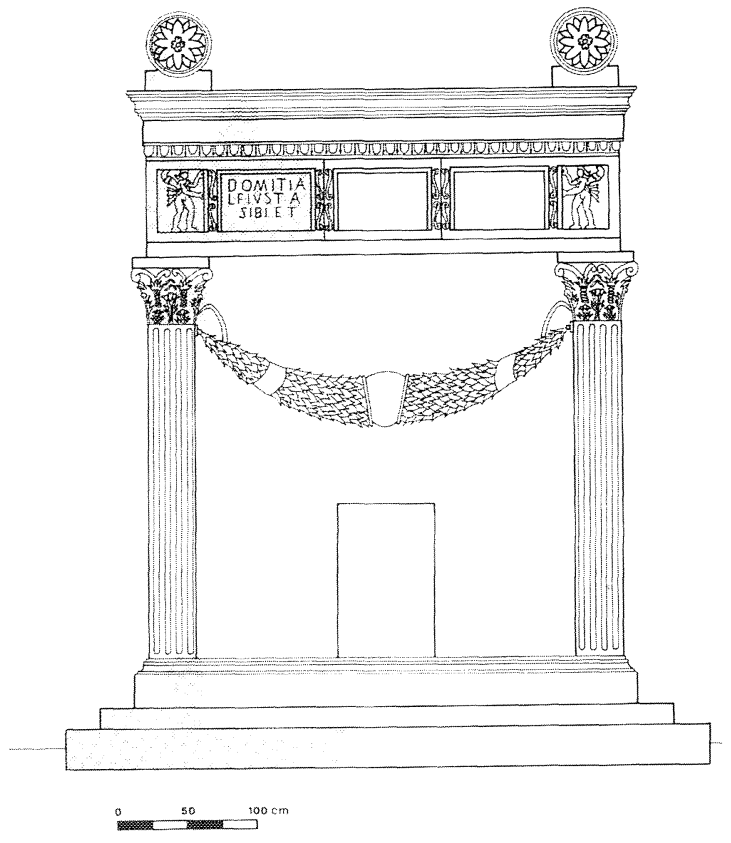

Fig. 14. Ensayo de restitución del frente del mausoleo de $\mathrm{La}$ Calerilla de Hortunas (Requena, Valencia), según Martínez Valle, 1995, fig. 17.

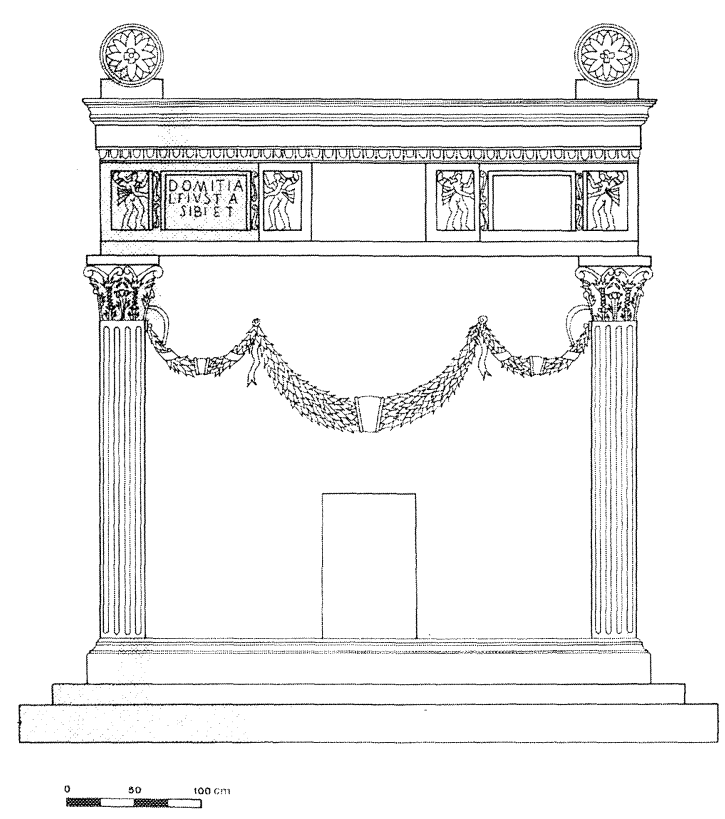

Fig. 15. Otro ensayo de restitución del frente del mausoleo de La Calerilla de Hortunas (Requena, Valencia), según Martínez Valle, 1995, fig. 18.

argumenta Martínez Valle (1995: 273), dadas las previsibles dimensiones del frente, deben faltar al menos otras dos columnas epigráficas, que se grabarían en otros tantos bloques, bien separados sólo por 


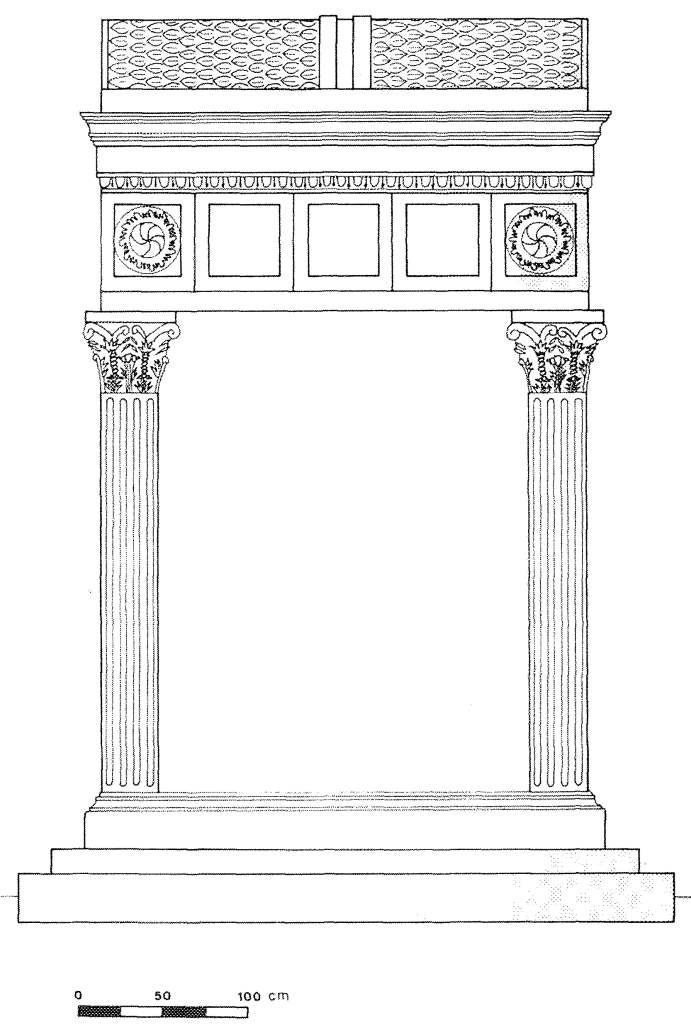

Fig. 16. Ensayo de restitución del lateral del mausoleo de La Calerilla de Hortunas (Requena, Valencia), según Martínez Valle, 1995, fig. 19.

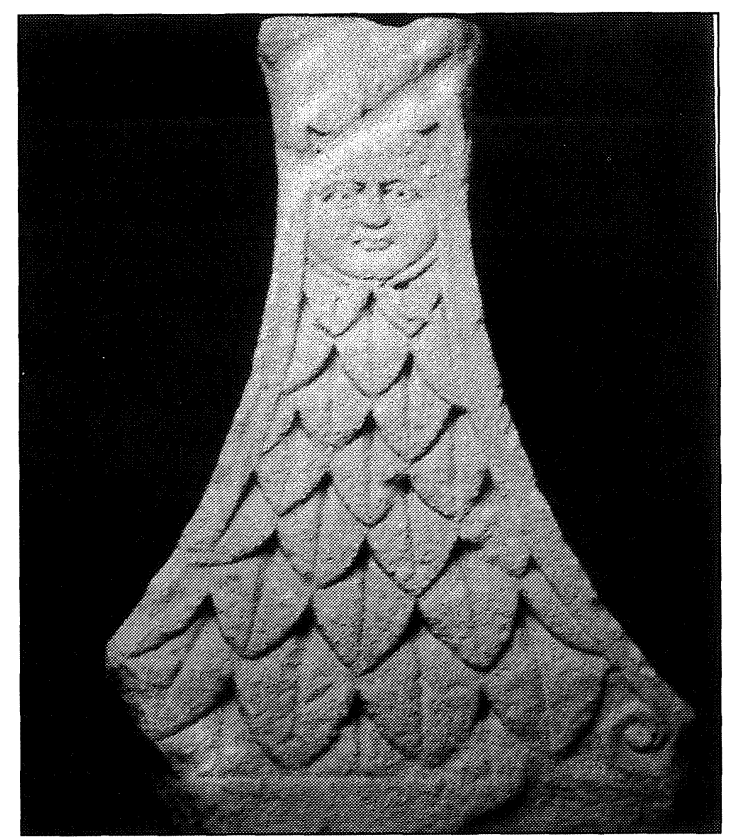

Fig. 17. Frontón con decoración de gorgoneion en el frente procedente de Las Eras de Ontur (Albacete), según Abad Casal, Abascal Palazón, Sanz Gamo, 2002, fig. 8. las volutas, bien incluyendo asimismo los erotes, lo que determina sus dos hipótesis de ensayo de restitución (Martínez Valle, 1995: figs. 17 y 18; cfr. Jiménez Salvador, 2002: 197, fig. 12) (figs. 14-15); más discutible es la disposición de la guirnalda de la segunda hipótesis reconstructiva, que, en efecto, debió colgar de la pilastra y de la que se advierte la representación del extremo de la taenia en el fragmento conservado ${ }^{26}$. El lateral debió tener una longitud de $3,90 \mathrm{~m}$, mientras que el pulvino sería de $2,90 \mathrm{~m}$, como restituye correctamente Martínez Valle (1995: fig. 19) (fig. 16). Ante la ausencia de estratigrafías claras para la datación del mausoleo, su editora concluye en una cronología de mediados del siglo I d.C., tanto por motivos del estilo de los relieves, sobre todo del capitel, cuanto porque considera que el mausoleo debió construirse en fecha anterior a la de los busta que lo acompañan, que los dató - como se dijo- en época flavia ${ }^{27}$. En conclusión, constituye el ejemplar de Requena uno de los más completos y mejor documentados de la serie hispana.

De excepcional interés son también los materiales que en fecha reciente han sido dados a conocer en la provincia de Albacete (Abad Casal, Abascal Palazón, Sanz Gamo, 2002), que aumentan de manera sustancial, tanto cuantitativa como cualitativamente, nuestro conocimiento de la arquitectura romana sepulcral de época altoimperial con monumentos básicamente turriformes, cuyas decoraciones externas en relieve se asemejan bastante a los -por otro lado cercanos - conjuntos giennenses del alto Guadalquivir, en concreto de Salaria, que refuerzan los argumentos ya expuestos con anterioridad que habían vinculado este sector albaceteño con el alto Guadalquivir a partir de las monedas y también de alguna estela funeraria (referencias en Abad Casal, Abascal Palazón, Sanz Gamo, 2002: 274). Los nuevos materiales corresponden a parte de paramentos de mausoleos con esquemas pseudoarquitectónicos de pilastras, bien aisladas o bien asociadas a guirnaldas o celosías, así como frisos con esvásticas y bloques epigráficos y retratos funerarios, que proceden sobre todo de El Tolmo de Minateda (Hellín) (cfr. Abad Casal, Gutiérrez Lloret, Sanz Gamo, 1998) y de otras localidades albaceteñas como Santa Ana de Abajo, El Pelao (Jorquera), Vizcable (Nervio), Libisosa (Lezuza) y Las Eras (Ontur). Precisamente del

\footnotetext{
${ }^{26}$ La primera opción se asemeja a la disposición de una gran guirnalda en el frente del mausoleo, como ocurre en los monumentos turriformes de Sofuentes (Fatás, Martín-Bueno, 1977b) o Numancia (Gutiérrez-Behemerid, 1993).

${ }^{27}$ Se aduce la presencia en uno de los busta de sigillatas sudgálicas y cerámicas de paredes finas de formas fechadas a partir de época de Claudio-Nerón (Martínez Valle, 1995: 278 , notas $105 \mathrm{~s}$.)
} 


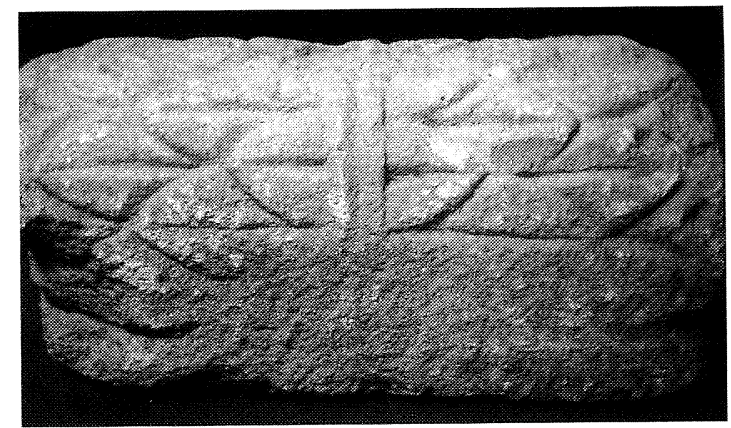

Fig. 18. Pulvino aparecido junto a la pieza anterior y procedente de Las Eras de Ontur (Albacete), según Abad Casal, Abascal Palazón, Sanz Gamo, 2002, fig. 9.

barrio de Las Eras de Ontur dan a conocer estos autores (Abad Casal, Abascal Palazón, Sanz Gamo, 2002: $272, \mathrm{n}^{\text {os }} 10-11$ ) dos piezas elaboradas en caliza, de gran interés, descubiertas casualmente, que corresponden a un frontón decorado en su frente con un gorgoneion (de 0,97 $\times 0,67 \times 0,24 \mathrm{~m})($ fig. 17) $\mathrm{y}$ a la parte central de un pulvino (de $0,26 \times 0,62 \times$ $0,30 \mathrm{~m}$ ) (fig. 18); lo excepcional del descubrimiento es - como argumentan los editores y sobre lo que volveremos a tratar más adelante en el apartado dedicado a las restituciones de las piezas - que los dos elementos corresponden efectivamente al coronamiento de un monumento en forma de altar con pulvinos (cfr. infra fig. 46).

\section{EL INTERIOR PENINSULAR: SEGOBRIGA}

En el interior meseteño de la Península Ibérica sólo podemos referir, por ahora, el importante conjunto de la ciudad de Segobriga (Saelices, Cuenca), que, amén de algunas piezas conocidas con anterioridad (ya citadas supra: Almagro Basch, 1978, 85 y lám. XIV; Gamer, 1989: CU 6, sin lámina) (fig. 19), ha sido catalogado y analizado en su totalidad por L. Baena del Alcázar (1993) (fig. 20). Éste relaciona hasta ocho fragmentos de pulvinos, fragmentados,

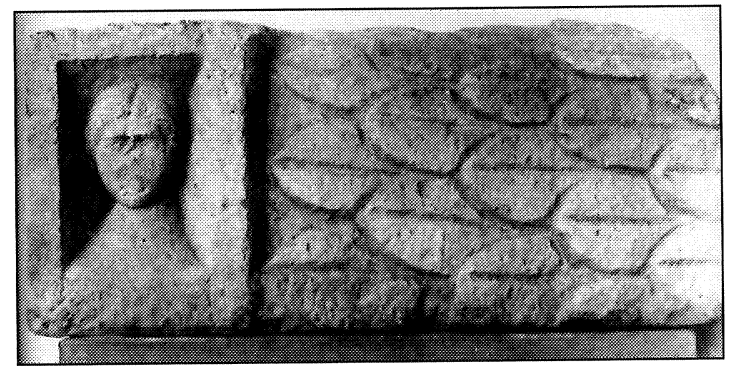

Fig. 19. Lateral de un pulvino de Segobriga, según Almagro Basch, 1978, lám. XIV.

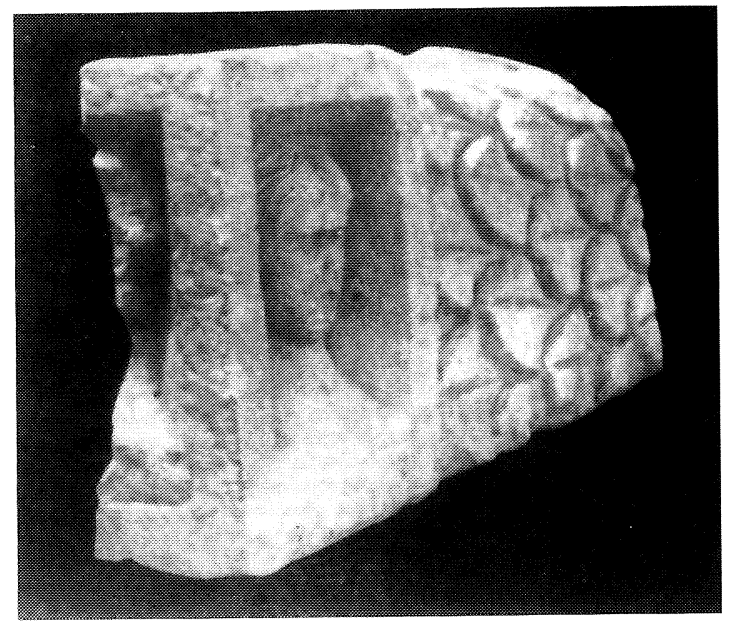

Fig. 20. Idem (visión frontal), según Baena del Alcázar, 1993, lám. I.

con medidas que oscilan entre $1 \mathrm{~m}$ y $0,37 \mathrm{~m}$ de longitud máxima, lo que permite a Baena del Alcázar poder restituir piezas que superan los dos metros; si bien los ejemplares están: todos elaborados en calizas locales y presentan la típica decoración de hojas imbricadas y el balteus central, que se ha conservado en un ejemplar, lo más significativo desde el punto de vista tipológico es la forma de los pulvinos, no cilíndrica, sino tendente a cuadrangular, y el hecho de que se rematen en los extremos con cubos decorados con bustos en dos de sus caras, la frontal y la lateral que quedaría vista en la parte alta del monumento. Estas representaciones figuradas deberían corresponder a retratos genéricos de los difuntos, pero con elementos que permiten su data en la primera mitad del siglo I d.C. (Baena del Alcázar, 1993: 153, cfr. esp. lám. II). La relación de fragmentos es la siguiente ${ }^{28}$ :

1. Fragmento de pulvino derecho, partido también longitudinalmente, que conserva uno de los frentes, rematado con un cubo, con sendos bustos en dos de sus caras, sin apreciarse restos del balteus (Baena del Alcázar, 1993: 148, nº 1, láms. I-II) (figs. 19-20).

2. Fragmento de pulvino izquierdo, que conserva también uno de los frentes, rematado con un cubo

\footnotetext{
${ }_{28}$ Baena del Alcázar (1993: 154) relaciona hipotéticamente algunos de estos pulvinos con «un gran monumento funerario in situ, en la propia Segóbriga, construido con sillares y decorado en sus esquinas por pilastras que rematan la parte superior con capiteles corintios». Esta edificación se sitúa en la vía norte de la ciudad y, en efecto, las dimensiones y la estructura del cuerpo de planta cuadrangular $(3,60 \mathrm{~m}$ en la cara frontal y $2,15 \mathrm{~m}$ en la lateral), con pilastras en las esquinas, hacen muy plausible esa hipótesis (lo visible actualmente de ese monumentum se reproduce fotográficamente en Almagro-Gorbea, Abascal Palazón, 1999: fig. 75).
} 
(en dos fragmentos que casan entre sí), con sendos bustos en dos de sus caras, sin apreciarse restos del balteus (Baena del Alcázar, 1993: 148s., $\mathrm{n}^{\circ} 2$, lám. III).

3. Fragmento de pulvino derecho, que conserva uno de los frentes, rematado con un cubo, con sendos bustos en dos de sus caras, sin apreciarse restos del balteus (Baena del Alcázar, 1993: 149, n 3, lám. IV-1).

4. Fragmento que conserva uno de los frentes, rematado con parte de un cubo, liso en este caso; quizás no fue nunca terminado, según apuntaba su editor, aunque también se podría pensar que correspondiera al extremo posterior (¿no decorado?) o, incluso, que las dos caras conservadas son las no decoradas (inferior y lateral interna) (Baena del Alcázar, 1993: 149, n 4, lám. IV-2).

5. Fragmento de la parte central de un pulvino, que conserva el balteus, decorado con hojas (Baena del Alcázar, 1993: 149s., nº 5, lám. V-1).

6-8. Tres fragmentos de cuerpos de pulvinos, sin restos del frente ni del balteus (Baena del Alcázar, 1993: 150, nos 6-8, láms. V-2, VI-1 y VI-2, respectivamente).

La singularidad del conjunto de pulvinos de $\mathrm{Se}$ gobriga, con las típicas terminaciones en cubos decorados con bustos en varias caras, debe justificarse por un carácter localista, que alteró el modelo original.

\section{EL ÁREA LUSITANA}

Si en el estado actual de conocimiento en el territorio de la Meseta el conjunto de Segobriga aparece totalmente aislado, las novedades aportadas en estos últimos años para la prouincia Lusitania han cambiado un panorama que era bastante similar hasta hace poco, ya que se consideraba el conjunto de pulvinos de Egitania como un fenómeno extraordinario por su singularidad - ya no sólo para Lusitania, sino para toda Hispania, con las únicas referencias de los pulvinos catalanes- y también por su aparición en esta ciudad de mediana importancia. A la catalogación realizada hacia mediados del siglo XX por F. de Almeida (1956: figs. 80-87) de las piezas portuguesas de Egitania (Idanha-a-Velha, en Beira Baixa), aparecidas todas ellas reutilizadas en la muralla tardorromana o medieval de la ciudad y conservadas en el museo de S. Dámaso, siguió su inclusión en el estudio ya citado de G. Gamer (1989: 57s., BEB 8 a 16, lám. 141a-d). Se trata de nueve pulvinos elaborados todos ellos en granito local, con formas cilíndricas, de cuerpo liso, y rosetas u otros

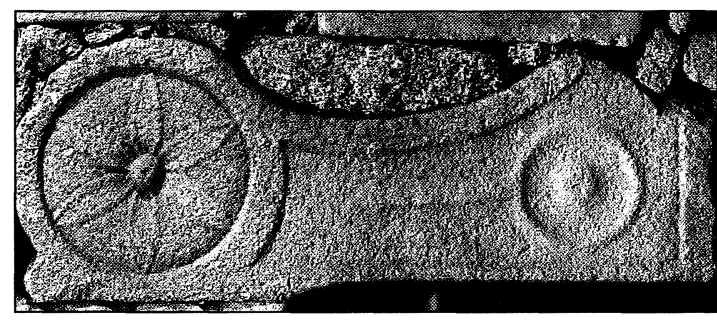

Fig. 21. Pulvino de Egitania (Idanha-a-Velha), según Gamer, 1989, lám. 141b.

elementos en el frente, que disponen desarrollados alargamientos laterales de perfil superior cóncavo, que se decoran también en el frente con diversos elementos, como patera con mango (Almeida, 1956: fig. 86; Gamer, 1989: BEB 9, lám. 141b) (fig. 21), hojas y una bandeja con un pescado (que asimismo es interpretada como un recipiente cultual), hojas con un significado más genérico, etc.; en algún caso se ha dispuesto otro pulvino cilíndrico de menores dimensiones al extremo del citado alargamiento lateral, asimismo decorado con roseta en el frente (Almeida, 1956: fig. 81; Gamer, 1989: BEB 11, lám. 141d). El estilo de las rosetas que de forma usual decoran el frente de los pulvinos, en diversos esquemas, responden a los mismos modelos que frecuentemente aparecen en la decoración de las estelas elaboradas en talleres locales de la mitad septentrional de Hispania (p.e., Abásolo, Marco, 1995: 327ss.). La extrañeza que podía producir esa serie de piezas cla-ramente interpretadas como coronamientos de mausoleos de clara raigambre romano-itálica, a pesar de su adaptación a materiales (granito), formas y estilos decorativos locales, queda en parte subsanada tanto por la importancia en época augustea de la ciuitas Igaeditanorum, cabeza de un distrito minero (pero que recibió la municipalidad sólo en época flavia), y sobre todo por la presencia de grupos de $u e$ terani (Almeida, 1977: 39ss.; Schattner, 1998: 110112).

Ahora conocemos otro importante conjunto de mausoleos similares en un entorno próximo de los territorios lusitanos, en concreto, en la propia capital Augusta Emerita. Así, el conjunto egitano no surge aislado en este sector del territorio hispano, sino que se imbrica con otros mausoleos similares en localidades cercanas, seguramente en relación con los gustos introducidos por colonos y que tenían, de nuevo, en el panorama capitolino provincial de Augusta Emerita un modelo de referencia. En efecto, a partir del pulvino monumental de Mérida ya conocido (Gamer, 1989: BA 53, sin lám.), hemos podido sumar en fecha más reciente una importante serie de doce pulvinos aparecidos en la Mérida romana, aun- 


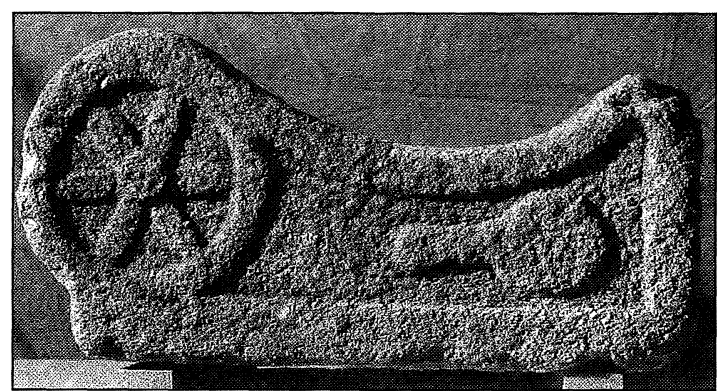

Fig. 22. Pulvino de Augusta Emerita, según Beltrán Fortes, Baena del Alcázar, 1996a, lám. 19, 2.

que en contextos de reutilización, conservándose once piezas en los fondos del Museo Nacional de Arte Romano y uno, in situ, reutilizado en los refuerzos de la muralla tardorromana en el sector de c/ Anas (Beltrán Fortes, Baena del Alcázar, 1996a) ${ }^{29}$. Además, hay que añadir otros nuevos ejemplares, asimismo reutilizados en construcciones posteriores, en el solar de c/ Morería (Nogales Basarrate, en Nogales Basarrate, Márquez Pérez, 2002: 124ss.).

Los pulvinos emeritenses se elaboran también en granito (fig. 22) y presentan bastantes similitudes formales con los mencionados de Egitania, dentro de una serie de variantes que nos dio pie para el establecimiento de una tipología básica (Beltrán Fortes, Baena del Alcázar, 1996a:124-131, figs. 5-16, láms. 18-23) (fig. 23); además, desde el punto de
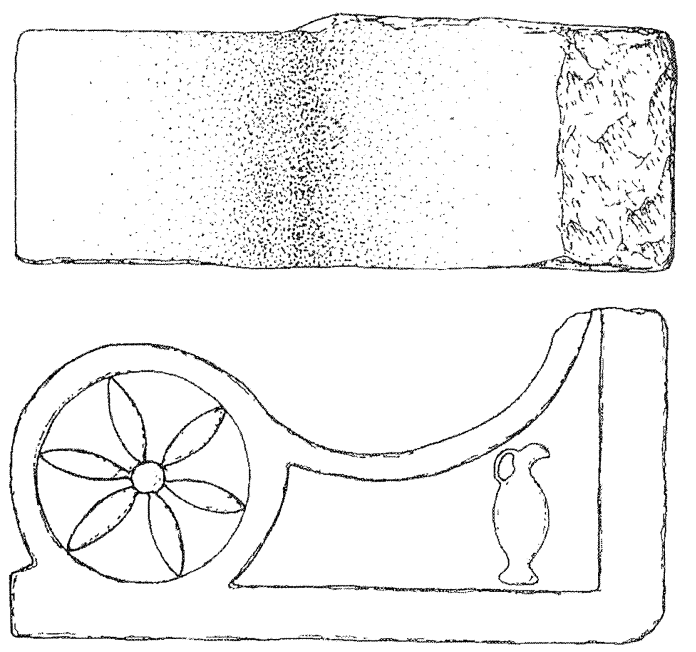

0 $50 \mathrm{~cm}$

Fig. 23. Dibujo de un pulvino emeritense, según Beltrán Fortes, Baena del Alcázar, 1996a.

${ }^{29} \mathrm{El}$ ejemplar citado por G. Gamer se recoge en el $\mathrm{n}^{\circ} 5$ de esta publicación. vista ornamental, junto a las rosetas que se sitúan en el frente del pulvino cilíndrico, se disponen objetos en relieve en el frente del alargamiento lateral, sobre todo de carácter cultual (patera, urceus, lituus), aunque asimismo un pájaro y un trisquele. Los situábamos entre los monumenta sepulcrales más tempranos de la nueva colonia y capital lusitana en época augustea, sobre todo por el uso del granito, teniendo en cuenta el proceso de uso de los marmora en Augusta Emerita (Beltrán Fortes, Baena del Alcázar, 1996a: 111s.) ${ }^{30}$. Por otro lado, hacíamos ya entonces referencia a las lógicas y tempranas relaciones entre la ciuitas Igaeditanorum y la capital lusitana como demuestra la donación en la primera de un orarium que fue sufragada, en el año 19 a.C., por el emeritense $Q$ (uintus). Iallius, Sexti f(ilius) (Beltrán Fortes, Baena del Alcázar, 1996a: 115).

Junto a las importantes series egitana y emeritense, también podemos aducir otros ejemplos de mausoleos en forma de altar en un marco territorial próximo a estos lugares, que amplían el área de expansión. En primer lugar, expusimos la hipótesis de que una pieza procedente de Trujillo (Cáceres), descrita y dibujada por el erudito del siglo XVII Juan Pérez Holguín ${ }^{31}$, correspondiera en realidad a un pulvino (Beltrán Fortes, Baena del Alcázar, 1996a: 115-117, con una argumentación más extensa). A pesar de que fue interpretada como una estela por sus primeros editores, creemos que su carácter anepigráfico, el resalte a la derecha (que interpretamos como una patera en relieve sobre el alargamiento lateral correspondiente) y, especialmente, los paralelos formales que ofrecen el resto de los pulvinos lusitanos, hacen posible esa reinterpretación. No debe olvidarse, además, que la regio Turgalensis, a pesar de su distancia con respecto a Augusta Emerita, fue una praefectura de esta colonia ${ }^{32}$, lo que justifica-

${ }^{30}$ Cfr., ahora, Nogales Basarrate (en Nogales Basarrate, Márquez Pérez, 2002: 123), cuando afirma al referirse a esa Mérida fundacional que «...la fisonomía augustana va indisolublemente asociada al material granítico de procedencia local...».

${ }^{31}$ El manuscrito de Pérez Holguín se titula Piedras de aras y sepulcros que o descubierto y copiado en esta noble y muy leal ciudad de Trujillo y está conservado en la Biblioteca Capitular y Colombina de Sevilla (ms. 82-3-16); fue dado a conocer por H. Gimeno Pascual y A. U. Stylow (1994: esp. 135, $\mathrm{n}^{\circ} 21$ ), aunque la pieza dibujada fue interpretada como una estela. A propósito de ella decía Pérez Holguín: «Esta piedra esta en el alberca que esta junto a la Vera Cruz y las estrias sobresalientes de medio relieve y el otro circulo los esta tambien levantado con una forma de tetilla y esta en el alberca que va dicho. Por la parte de adentro en la pared de los ultimos escalones, fue obra de romanos según tradicion, y conocese por unas piedras de canteria de muy gran magnitud que estan en ella atravesadas unas sobre otras...» (Ibid., fol. 8).

${ }^{32}$ Citado por Higinio, De Lim. Const. 171, 6-10 y fig. 140 La; cfr. López Paz, 1993: 741ss. 


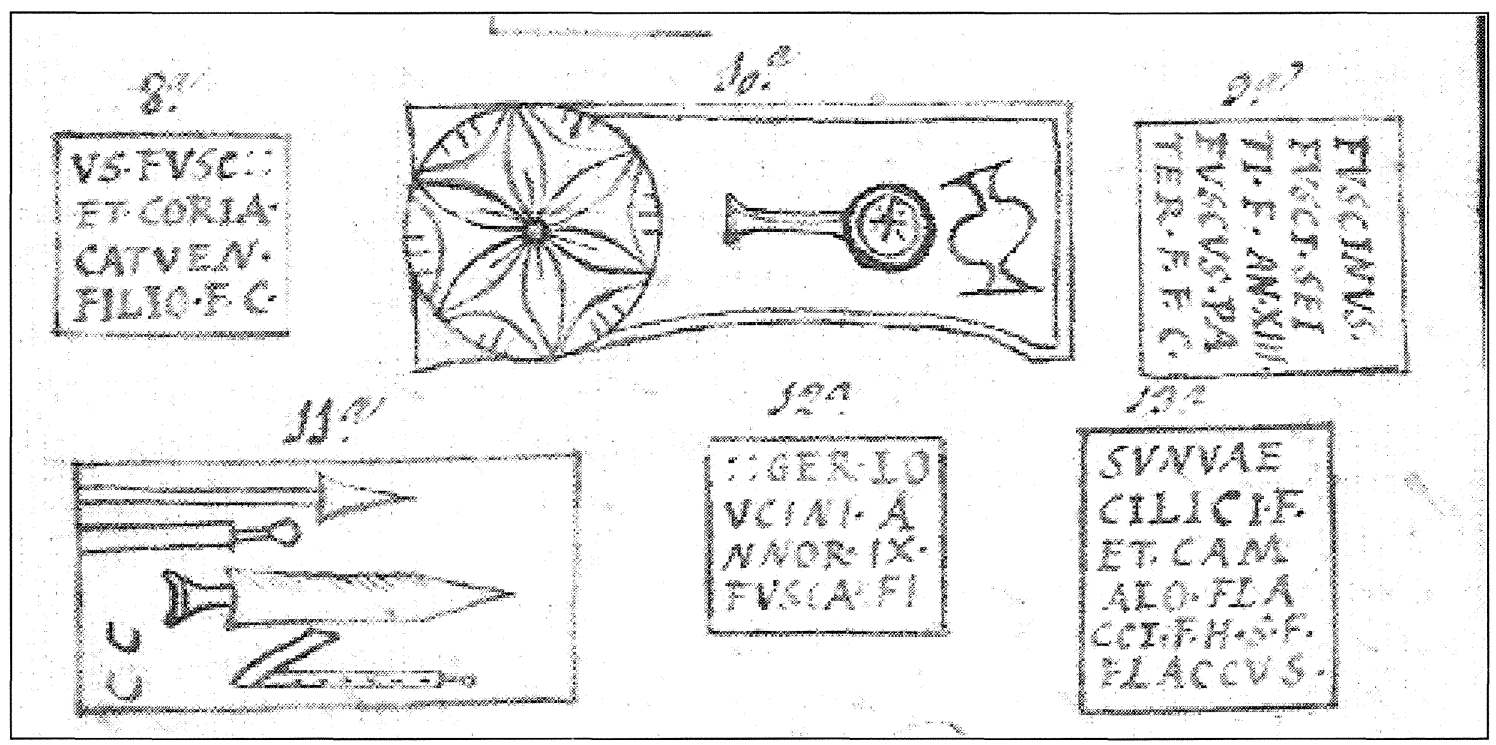

Fig. 24. Dibujos de piezas de Coria (Cáceres), recogidas en el informe enviado por F. Guerra en 1840 a la Real Academia de la Historia sobre inscripciones, según Cebrián Fernández, 2002, fig. 69. El pulvino, con el $\mathrm{n}^{\circ} 10$, se ha dibujado en posición inversa. En el mismo contexto de reutilización se encontraron las piezas ${ }^{\text {os }} 11$ (relieve de armas), 8 y 9 (dos epígrafes incompletos de miembros de una misma familia), por lo que bien pudieron pertenecer al mismo monumento sepulcral.

ría la presencia en Trujillo de un mausoleo en forma de altar siguiendo los propios modelos de la capital lusitana.

En esta misma línea podemos aportar ahora otro testimonio manuscrito que nos parece que documenta la existencia de otro pulvino, no conservado, pero conocido por un dibujo del siglo XIX (fig. 24), del que se deduce que era de similar tipología a los citados antes, y que se sitúa en la también localidad cacereña de Coria, ta romana Caura, en un sector geográfico por tanto próximo al conjunto de Idanhaa-Velha. El dato se recoge en un informe que sobre las inscripciones de esa localidad cacereña remitió a la Real Academia de la Historia Felipe Guerra el 18 de febrero de 1840; en una de las páginas del informe se dice: «Las $8^{a}, 9^{a}, 10^{a}$ y $11^{a}$ salieron al deshacer un poco del muro cerca del castillo, p(ar)a edificar la hacera nueba de casas de la caba. Las dos primeras estan en casa de Bartolomé Pedraza, la $3^{a}$ en el corral de D. José Lamo, y la $4^{a}$ forma p(ar)te de las jambas de la puerta pr(incip)al de la casa de D. Antonio Bellido» (Cebrián Fernández, 2002: 213, ref. CAI-CC/9/3931/4, fig. 69).

La pieza que nos interesa es numerada con el $n^{\circ}$ $10 \mathrm{y}$, aunque colocada en el dibujo en posición inversa, claramente se adivina que corresponde al frente de un pulvino derecho, con el perfil cóncavo del alargamiento lateral, recorrido en el borde con un listel liso y decorado en su frente con objetos cultuales (en este caso se unen el urceus y la patera manicata), a la vez que coloca la roseta hexapétala y con botón central en el frente del pulvino, siguiendo claramente el modelo de los ejemplares emeritenses que hemos analizado. Es interesante mencionar al menos las otras tres piezas que aparecieron junto al pulvino, reutilizadas en el mismo sector del muro, aunque no existe constancia lógicamente de que formaran parte del mausoleo en forma de altar. Sí parece significativo que una de ellas $\left(\mathrm{n}^{\circ} 11\right)$ corresponda a un sillar con decoración en relieve en uno de sus frentes, de difícil interpretación exacta (se representan al menos unas armas, el extremo de una lanza y una espada, junto a otros dos objetos no identificados, y lo que parecen dos letras epigráficas: CC), pero que podría adscribirse a la ornamentación externa de un monumento sepulcral, donde los relieves de armas son frecuentes. Las otras dos piezas $\left(\mathrm{n}^{\text {os }} 8\right.$ y 9) corresponden a incompletos epígrafes funerarios; en el primero, los padres, [-]us. Fusc $[i$ f(ilius)] y Coria, lo dedican al hijo ${ }^{33}$; en el segundo, se menciona al padre Fuscus que dedica la inscripción a su hijo de trece años, Fuscinus Fusci Sex-

${ }^{33}$ CIL II, $\mathrm{n}^{\circ}$ 780. Pieza desaparecida, se recoge ahora en Sánchez Albalá, Vinagre Nevado, 1998: 82, n 68 (con bibliografía anterior), que la identifican como una estela y para quienes la trascripción es: ...us. Fusc[i f(ilius)] / et. Coria / Catuen(o) / filio. f(aciendum). c(urauerunt), siendo pues Catueno el nombre del hijo. Sin embargo, es asimismo posible que estemos ante el antropónimo de la madre - Catuen $(i)$ - y que el nombre del hijo se colocara al inicio de la inscripción. 


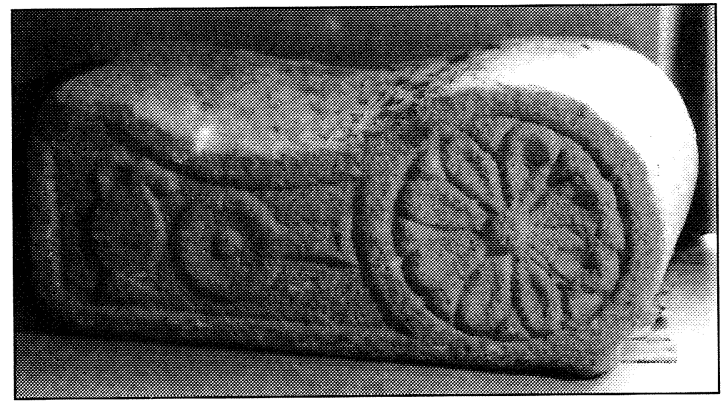

Fig. 25. Pulvino de Coria (Cáceres), según Sánchez Albalá, Vinagre Nevado, 1998, $\mathrm{n}^{\circ} 94$.

ti f(ilius $)^{34}$. Dado que ambos parecen corresponder a la misma familia y la similar procedencia (si bien de un claro contexto de reutilización), bien podrían haber pertenecido las cuatro al mismo mausoleo familiar, que quizás - en plano meramente hipotético- tuvo forma de altar coronado con pulvinos y decoró el cuerpo de opus quadratum con relieves de armas e inscripciones.

Dejando al lado tales especulaciones, sí podemos corroborar ahora de forma fehaciente la existencia de pulvinos de similar tipología en el solar coriano ${ }^{35}$. En primer lugar, mencionaremos un pulvino de granito, de $0,38 \mathrm{~m}$ de altura, $0,90 \mathrm{~m}$ de anchura y $0,45 \mathrm{~m}$ de grosor (fig. 25), de similar tipología que la pieza dibujada en el siglo XIX; se trata de un ejemplar que fue hallado «al derrumbarse un tapial en el Arrabal de Cantarranas, [donde] se hallaba situada como canal de desagüe» ${ }^{36}$, pero es tal la semejanza que tiene con la pieza citada que surge la duda de que se trate del mismo pulvino dibujado en 1840 , o en todo caso es de tipología similar. Se trata también de un pulvino derecho, que se decora en el frente del alargamiento lateral con la representación de una patera con umbo y mango y de un urceus, colocados en la misma disposición que los del dibujo; las diferencias estriban en que en el dibujo el urceus no lleva asa (un evidente error del dibujante) y, sobre todo, en el diseño de la roseta que decora el frente del pulvino, ya que en el dibujo se representó una roseta de seis pétalos de perfil apuntado y la pieza conservada tiene ocho de perfil redondeado. Quizás por ello debe-

\footnotetext{
${ }^{34} \mathrm{CIL}$ II, $\mathrm{n}^{\circ}$ 779. Asimismo se trata de una pieza no conservada en la actualidad, que recogen Sánchez Albalá, Vinagre Nevado, 1998: 54, $\mathrm{n}^{\circ}$ 40, (con bibliografía anterior).

35 Agradezco al profesor José Antonio Abásolo haberme indicado la existencia de estos dos pulvinos de Coria.

${ }^{36}$ Sánchez Albalá, Vinagre Nevado, 1998: 109, nº 92 (no se trata de un ara de libaciones). Desconocemos más datos sobre el contexto de descubrimiento, por lo que no podemos afirmar si podría haber sido reutilizada en este lugar posteriormente a 1840 . Hoy en día se conserva en el Ayuntamiento de Coria.
}

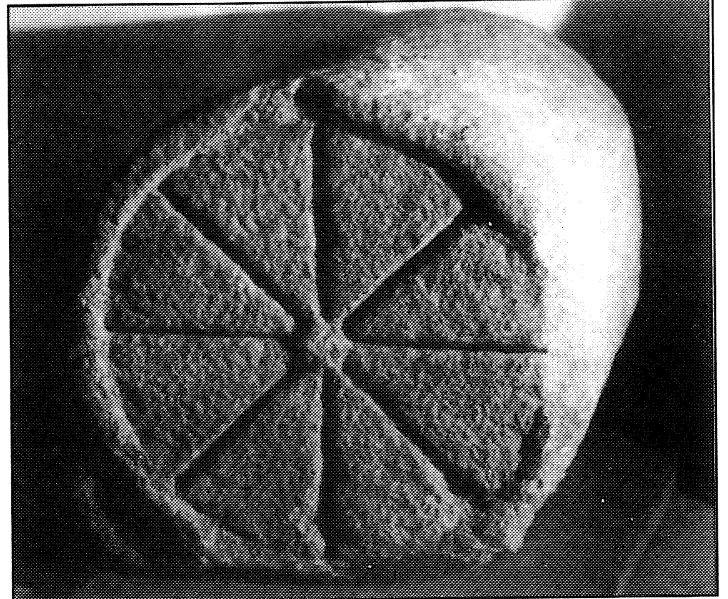

Fig. 26. Pulvino asimismo procedente de Coria (Cáceres), según Sánchez Albalá, Vinagre Nevado, 1998, nº 93.

ríamos pensar en que se trate de otra pieza, justificado además en el diferente contexto de descubrimiento, que en ese caso documentaría otro monumento en forma de altar gemelo al anterior.

Por otro lado, entre esas piezas arqueológicas recogidas actualmente en el Ayuntamiento de Coria y recuperada, esta vez, «durante las obras de restauración en el tramo de la muralla romana de la $\mathrm{Ca}$ lle del Horno, en 1996» ${ }^{37}$, podemos reconocer asimismo otro pulvino monumental (fig. 26), que también correspondería a la pieza de coronamiento de la parte derecha del mausoleo ${ }^{38}$. Se elabora asimismo en granito, pero presenta fracturado el alargamiento lateral, por lo que las dimensiones conservadas son de $0,36 \mathrm{~m}$ de altura, $0,38 \mathrm{~m}$ de anchura $\mathrm{y}$ $0,40 \mathrm{~m}$ de grosor; en este caso sólo conservamos la decoración del frente del pulvino propiamente dicho, que es también una roseta de ocho pétalos, pero ejecutados de forma mucho más esquemática, sin el naturalismo de la roseta del pulvino anterior.

Finalmente, aunque no corresponde ya a tierras lusitanas, a caballo con el territorio vecino del bético conuentus Cordubensis, mencionaremos otro pulvino de claras similitudes formales y que, también elaborado en granito local, fue dado a conocer por A. U. Stylow (CIL II ${ }^{2} / 7, \mathrm{n}^{\circ} 943$ ), procedente del ager de Iulipa, en Esparragosa de la Serena ${ }^{39}$. El

\footnotetext{
${ }^{37}$ Sánchez Albalá, Vinagre Nevado, 1998: 108, nº 93.

${ }_{38}$ No creemos que se trate - como indican sus editores (cit. en nota anterior) - de la cabecera de una lápida sepulcral, ya que aparte del inicio del alargamiento lateral, se reconoce fácilmente el plano de asiento del pulvino, tal como se recoge en la fotografía.

${ }^{39}$ En Iulipa, en Zalamea de la Serena, se conserva el singular mausoleo romano rematado por un dístilo (esp. García y Bellido, Menéndez Pidal, 1963).
} 
pulvino se conserva empotrado en una construcción de la finca «el Toril del Moro» o «de los Caballos» y mide 0,33-38 $\mathrm{m}$ de altura y 0,71 $\mathrm{m}$ de anchura, con alargamiento lateral de perfil superior cóncavo, aunque truncado en el ángulo superior izquierdo, que corresponde a un pulvino derecho. La decoración se asimila a la serie lusitana que ya hemos mencionado, con una simple roseta hexapétala y botón central en el frente del pulvino, el frente del alargamiento lateral delimitado por una moldura simple y el campo decorado con una patera.

\section{ANDALUCÍA}

En el artículo de 1990 di a conocer precisamente una serie de nueve pulvinos del territorio andaluz: cinco de los actuales territorios giennenses, dos de Ossigi (Jimena de la Frontera), otros dos de Castulo (Linares), uno de Tucci (Martos) y, finalmente, dos del Museo de Jaén, que entonces eran de procedencia exacta desconocida, aunque uno sí podemos adscribir ahora también a Ossigi. Los otros dos procedían respectivamente de Ilurco (Pinos-Puente, Granada) y de Osqua (Villanueva de la Concepción, Málaga), en Andalucía oriental. También ahora podemos aumentar el número de piezas conocidas, documentando su uso en ámbitos de Andalucía occidental.

\section{Andalucía Occidental}

El primer ejemplar de Andalucía occidental remite a la misma serie de pulvinos que acabamos de analizar para la Lusitania, elaborados en granito, de formas cilíndricas lisas, pero con un peculiar y desarrollado alargamiento lateral, que se eleva en el extremo. Es algo lógico si tenemos en cuenta que procede de un ámbito cercano, que, en época romana, se englobaba también en el mismo conuentus Cordubensis. Pulvino inédito hasta ahora, empotrado en uno de los muros del castillo medieval de Belalcázar, en el norte de la actual provincia de Córdoba, ha sido dado a conocer recientemente por D. Vaquerizo (2001a: 144, nota 28, fig. 10). Tiene unas dimensiones aproximadas de un metro de longitud y el pulvino un diámetro de $0,30-0,40 \mathrm{~m}$, dado que su colocación actual ha impedido tomar sus medidas exactas. En la fotografía publicada se observa la existencia de una roseta hexapétala con botón central — similar a las analizadas - y un relieve no identificado en el frente del alargamiento, pero que responde, pues, a un esquema similar al de las piezas lusitanas.

Diverso es el panorama que ofrece la capital bé-

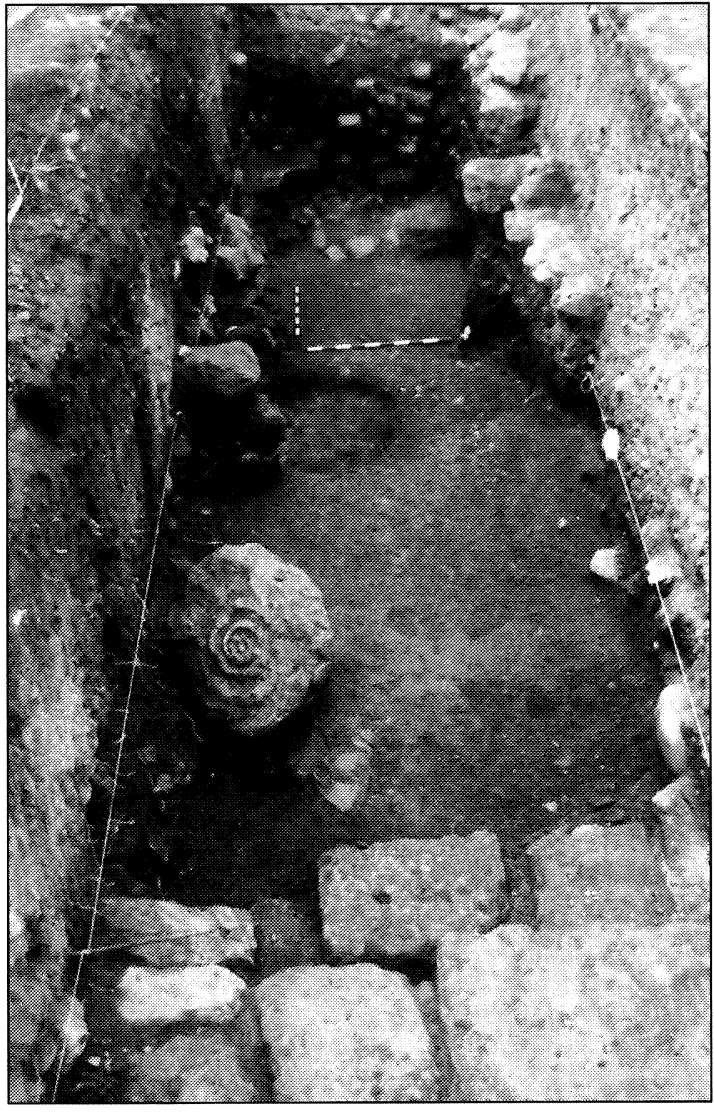

Fig. 27. Fotografía del ámbito de aparición de un pulvino de Córdoba, en la zona de la torre de la Malmuerta.

tica, la colonia Patricia (Córdoba), gracias a los resultados del proyecto de investigación que en estos últimos años ha dirigido D. Vaquerizo (cfr. AA.VV., 2001; AA.VV., 2002: 141ss.). Así, conocemos de la capital de la Bética dos nuevos ejemplares de pulvinos, siendo uno de ellos el de mayor tamaño de los conocidos hasta ahora; el fragmento, elaborado en piedra caliza local, presenta un diámetro de $0,75 \mathrm{~m}$ y decora el cuerpo con hojas imbricadas con nervio central, mientras que en el frente se sitúa una pequeña roseta de ocho pétalos en el centro de un motivo espiral, que se desarrolla desde el centro y - seguramente, si tenemos en cuenta otros paralelos- se extendería por un posible alargamiento lateral (Vaquerizo Gil, 2001: fig. 11, A; y 2002b: fig. 22; Márquez Moreno, 2002: 224, lám. 1). A pesar del deterioro de la pieza conservada, el que no sea de sección cilíndrica exacta parece apuntar, en efecto, a la existencia de ese alargamiento. El fragmento apareció reutilizado en niveles medievales en el curso de la excavación de urgencia en un solar de la c/ Adarve, $\mathrm{n}^{\circ} 2$ (fig. 27), aunque - como indica 

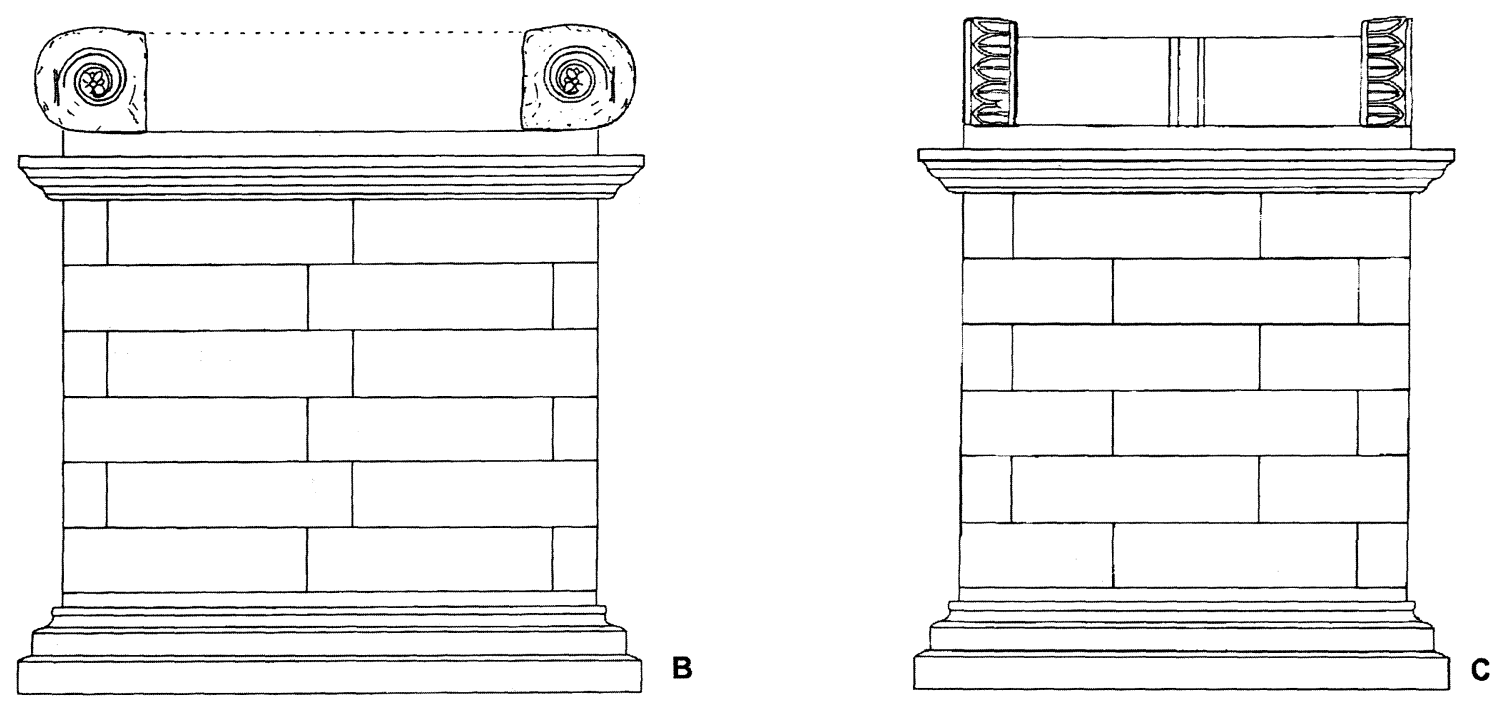

Fig. 28. Hipótesis de restitución del frente y lateral del monumento en forma de altar de Córdoba, coronado con el pulvino reproducido en la figura anterior, según Vaquerizo Gil, 2001, fig. 11, B-C.

su editor- es posible que originalmente se relacionara con un basamento de opus caementicium documentado en el mismo solar de la excavación, con una base rectangular de $3,50 \mathrm{~m} \times 2,50 \mathrm{~m}$, y que éste fuera el zócalo del mausoleo en forma de altar coronado por el pulvino, lo que en efecto avala el que este ejemplar correspondiera al tipo en que el cuerpo del altar conforma la propia cámara funeraria (Vaquerizo Gil, 2001: 145, nota 34 y fig. 11, B-C; y 2002b: 188s., nota 90; para su contexto de aparición, Carmona, Moreno, Bermúdez, 1997: 28 y 33s.) (fig. 28).

También publica D. Vaquerizo (2001: 144, fig. 9; y 2002b: 188, fig. 20; además, Márquez Moreno, 2002: 224s., lám. 2) otro fragmento de pulvino aparecido en Córdoba, también en el curso de una excavación de urgencia en la Avda. de la Victoria. Asimismo ejecutado en piedra caliza local, sólo se ha conservado la parte central del balteus, con un anillo de astrágalos del que surgen a cada lado sendas coronas de hojas ${ }^{40}$ (fig. 29); se trataría de una adaptación formal por parte de un taller local ${ }^{41}$. Amén de los restos de opus caementicium de la c/ Adarve, que pudieron corresponder al mausoleo citado, también conocemos la existencia de restos arqueológicos correspondientes a mausoleos que pu-

\footnotetext{
${ }^{40}$ La pieza debió sufrir una reutilización, como fruto de la cual se advierte en una de las caras de fractura una oquedad rectangular.

${ }^{41}$ Tiene ciertas concomitancias con el ejemplar documentado de Vélez-Rubio (Almería), que citaremos luego.
}

dieron haber tenido este mismo esquema arquitectónico, como en la Avda. de las Ollerías, n 14 (en la necrópolis septentrional de la colonia), donde se documenta una estructura cuadrangular de opus quadratum, o los documentados en los comedios del siglo XX en el «Camino Viejo de Almodóvar», asimismo construidos a base de sillares (Vaquerizo Gil, 2001: 150 y 152 , respectivamente).

Siguiendo el curso del Guadalquivir hacia su desembocadura, encontramos otras dos localidades en las que se constata la existencia de mausoleos en forma de altar, aunque con un desarrollo diverso. No se tenía hasta ahora constancia en Italica (Santiponce) de la presencia de elementos que puedan corresponder a tumbas romanas monumentales (cfr. González Parrilla, 2001), a pesar de que sí se había apuntado una interesante hipótesis, considerando

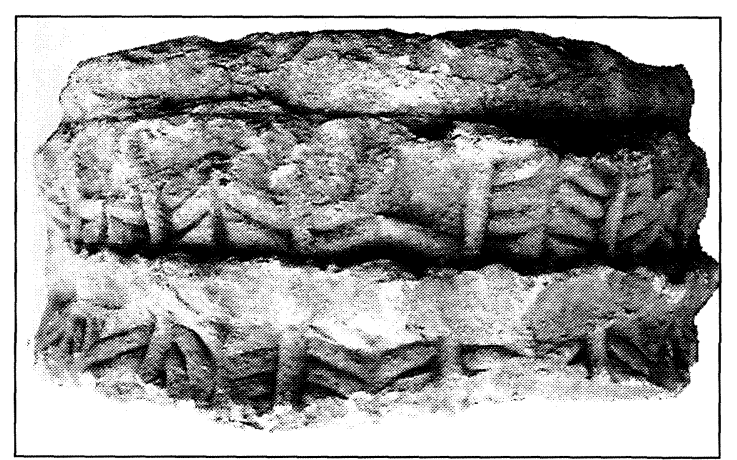

Fig. 29. Fragmento central de otro pulvino de Córdoba, según Vaquerizo Gil, 2001, fig. 9. 


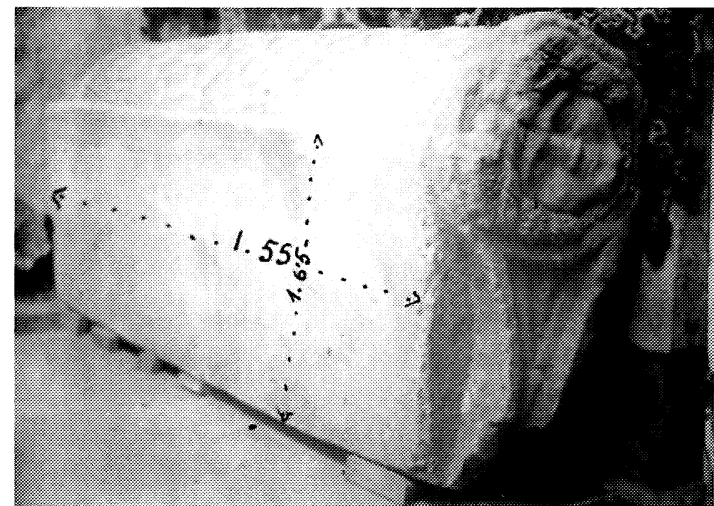

Fig. 30. Bloque marmóreo decorado con un pulvino, procedente de Italica (Santiponce), y sólo conocido por esta fotografía de comienzos del siglo XX de José Gestoso y Pérez, conservada en la Biblioteca Capitular y Colombina de Sevilla.

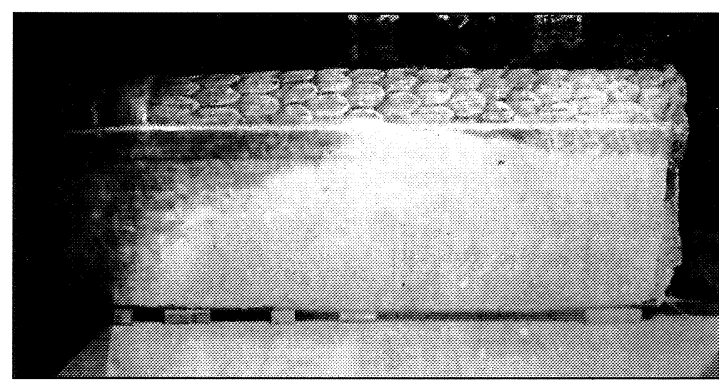

Fig. 31. Idem. Vista superior. Fotografía de la Biblioteca Capitular y Colombina de Sevilla.

como restos de estructuras sepulcrales las representadas en un grabado inglés de mediados del siglo XIX, correspondiente a la necrópolis meridional (Caballos Rufino, Marín Fatuarte, Rodríguez Hidalgo, 1999: 123). Ahora sí tenemos esa certeza a partir de una pieza actualmente desaparecida, pero que fue conocida y fotografiada por el erudito sevillano José Gestoso y Pérez a fines de 1915, aunque desconocemos las características del descubrimiento, dónde se conservaba o su localización actual; en realidad sólo la documentamos por dos fotografías conservadas entre los papeles de José Gestoso Pérez de la Biblioteca Capitular y Colombina de Sevilla ${ }^{42}$ (figs. 3031 ), sin que se haya conservado ninguna referencia manuscrita explícita ${ }^{43}$. Al pie de la fotografía, escri-

\footnotetext{
${ }^{42}$ Se encuentran en el tomo XXXVI de los Papeles Varios del «Fondo Gestoso», fechado en la portada en 1914, pero que también incluyen del año siguiente, como ocurre en el caso de las fotografías que nos ocupan. Sobre este personaje y su actuación en Italica, cfr. ahora Beltrán Fortes, 2002c.

${ }^{43}$ En una de las fotografías anotó J. Gestoso las dimensiones del bloque: $1,55 \mathrm{~m}$ de longitud y -posiblemente- 0,65 $m$ de anchura de la parte superior lisa, aunque por error se indicara $1,65 \mathrm{~m}$, puesto que evidentemente $10 \mathrm{~s} 65 \mathrm{~cm}$ sí serían proporcionales a la longitud indicada.
}

bió el erudito sevillano lo siguiente: «Italica. Trozo decorativo de mármol blanco descubierto por el arado Diciembre 1915 en una de las hazas de los Palacios, propiedad de D. Carlos García Velasco.»

Si tenemos en cuenta que el fragmento correspondía a una mitad y al balteus la pieza completa debía medir cerca de tres metros de longitud. El pulvino italicense, que se situaría en la parte derecha del coronamiento correspondiente, presenta evidentes diferencias con respecto a muchos de los analizados hasta ahora. En primer lugar, el uso del mármol, material inusual en este tipo de monumentos sepulcrales ${ }^{44}$, y especialmente la forma del coronamiento, que constituye un bloque cuadrangular en uno de cuyos extremo y lateral se ha delimitado el pulvino cilíndrico, pero no en la parte superior, donde permanece la superficie lisa del bloque original. El cuerpo del pulvino presenta catorce filas de hojas imbricadas, dispuestas a partir del balteus, constituido mediante un elemento hemiesférico moldurado y, en el centro, otro elemento cilíndrico liso, de menor diámetro. El frente del pulvino presenta una decoración de gorgoneion, que remite, pues, a la ornamentación de los ejemplares catalanes ya analizados, mientras que el alargamiento lateral, que se realza sobre el fondo de esta cara del bloque original, sólo presenta un grueso enmarque liso y, en su interior, el mismo esquema triangular grabado mediante incisión. No puede identificarse con exactitud el lugar de donde procede la pieza, ya que el topónimo de «Los Palacios» no designa un espacio concreto en el yacimiento italicense $\mathrm{y}$, además, ha sido utilizado con valores diversos durante los siglos XVIII al XX ${ }^{45}$; sin embargo, parece que en los primeros decenios del siglo XX el topónimo de las «hazas de los Palacios» se referiría de forma más estricta a los olivares de la «Cañada Honda» ${ }^{46}$, ocupando, pues, parte de la expansión urbana de los primeros decenios del siglo II d.C. En este sector cabe mencionar en primer lugar, en la zona sur de la «Cañada Honda», parte de la necrópolis oriental, entre las murallas y el río; en segundo lugar, en la zona norte, la gran necrópolis occidental, a la que más probablemente pudo corresponder la pieza. Es factible que el monumento funerario hubiera sido erigido en esa necrópolis después

\footnotetext{
${ }^{44}$ Sólo otro ejemplar bético, procedente de Martos, que veremos luego, aparece realizado en mármol y no en caliza o arenisca.

${ }^{45}$ Como indica P. León (1995: 22) ese topónimo «...ha designado en Itálica una vasta extensión de terreno que abarca prácticamente la parte excavada de la Nova Urbs y un amplio sector de la Vetus Urbs, conocido éste también como 'Eras del Convento' o 'del Monasterio'».

${ }^{46}$ Agradezco a J. M. Rodríguez Hidalgo (Delegación Provincial de Cultura de Sevilla) y a F. Amores Carredano (Univ. de Sevilla) sus indicaciones en este sentido.
} 


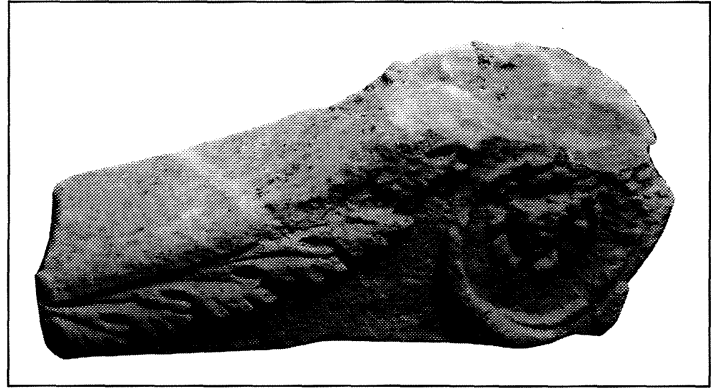

Fig. 32. Pulvino de Conobaria (Las Cabezas de San Juan, Sevilla). Colección Municipal.

de la citada ampliación urbana de época trajanoadrianea, ya que el uso del mármol, la forma inusual del pulvino — con el bloque original- y el estilo del relieve de la gorgona podrían apuntar a una fecha de la primera mitad del siglo II d.C. Es posible que fuera un aspecto más de ese carácter tradicionalista que en ciertos aspectos tuvo la sociedad italicense (Caballos Rufino, 1994: 126ss.), ya que los monumentos en forma de altar habrían sido especialmente utilizados en Hispania durante la centuria anterior.

En este sector occidental de la Bética y aún en la provincia de Sevilla, daremos a conocer un monumental pulvino procedente de Las Cabezas de San Juan (Sevilla) ${ }^{47}$ (fig. 32), donde se sitúa una ciudad romana que, desde el siglo XVII, había sido identificada erróneamente como Vgia, municipio augusteo citado como mansio de la uia Augusta, que debe localizarse en el cercano yacimiento de «Torres de Alocaz» (Utrera). Hemos ya planteado la posibilidad de que en Las Cabezas de San Juan deba fijarse la ciudad de Conobaria (Beltrán Fortes, 1999 y 2000), municipio flavio que tuvo una evidente importancia en este antiguo sector costero del lacus Ligustinus desde época tardorrepublicana ${ }^{48}$. El pulvino que analizamos corresponde a un ejemplar que iría colocado en la parte derecha del coronamiento del altar, elaborado en arenisca y decorado en el lateral con las típicas hojas imbricadas, apuntadas y con nervio central, mientras que en el frente se dispone un motivo espiral cuyo centro ocupa un rostro antropomorfo en el centro de una roseta de ocho pétalos; el pul-

\footnotetext{
${ }^{47}$ Cfr. Beltrán Fortes, 2002a: 254, fig. 17.

${ }^{48}$ Lo demuestra la probable procedencia de este lugar del ius iurandum a Augusto y la Domus Augusta del 6-5 a.C., el más temprano de los conocidos en Occidente, grabado en una placa incompleta de bronce (González Fernández, 1996: $\mathrm{n}^{\circ}$ 990, fig. 583). También en la segunda mitad del siglo a.C. aparece enterrado un conobariensis en la ciudad de Carthago Nova, CIL II: $\mathrm{n}^{\circ}$ 3444; Abascal Palazón, Ramallo Asencio, 1997: 265ss., $n^{\circ} 84$
}

vino dispone un largo alargamiento lateral, en el que se alarga uno de los extremos del motivo espiral antes citado, que se orna con medias hojas de acanto en uno de sus lados; es similar en la disposición al pulvino que mencionaremos más delante procedente de Ilurco ${ }^{49}$. El motivo representado en el centro del motivo espiraliforme podría corresponder a una representación idealizada del difunto - como se dispone en algún caso de forma más clara-, aunque no podría descartarse que fuera un personaje no humano, como una figura genérica que aparece en ocasiones en el contexto de las decoraciones vegetales, con una simbología bien conocida (p.e., Toynbee, Ward-Perkins, 1950; Balil Illana, 1958). Aunque el motivo se desarrolla sobre todo desde época flavia en variados contextos, en ámbitos funerarios ya se documentan desde los momentos tardorrepublicanos (p.e., Ortalli, 1983: 58ss.; Rodá de Llanza, 2000: 179 y lám. 19). Una cronología entre momentos augusteos y mediados del siglo I d.C. es adecuada para el ejemplar cabeceño, del que hemos podido saber que apareció, de forma casual, en la necrópolis oriental de la ciudad, de donde asimismo proceden varios leones funerarios (Beltrán Fortes, 2000) y dos retratos femeninos sedentes (Beltrán Fortes, 2002a: 242, fig. 7), correspondientes a otros mausoleos de tipología diversa (edificios turriformes con edícula para la exposición de las estatuas-retratos, monumentos coronados con leones), que coincidirían junto al mausoleo en forma de altar con pulvinos en aquella necrópolis urbana durante momentos tardorrepublicanos o altoimperiales, conformando una típica imagen sepulcral de ciudad romana.

\section{El Alto Guadalquivir: los territorios giennenses}

Del conjunto de pulvinos que editamos en 1990 siete ejemplares procedían de Jaén y, con casi con total seguridad, tres de Ossigi (Beltrán Fortes, 1990). Esta última ciudad, que se sitúa en el «Cerro Alcalá» (Jimena de la Frontera) y de la que dice Plinio $(\mathrm{NH}, 3,10)$ «...quod cognominatur Latonium», fue municipio seguramente ya en época de César (CIL II $2 / 7$, 1ss.; González Román, Mangas Manjarrés, 1991: 373ss.). En efecto, ya indicamos entonces que probablemente fuera de esa procedencia un ejemplar conservado en los jardines del $\mathrm{Mu}-$ seo Arqueológico de Jaén, elaborado en caliza y que mide $1,70 \mathrm{~m}$ de longitud y $0,40 \mathrm{~m}$ de grosor (Beltrán

49 También representaciones de cabezas en el centro de clípeos se documentan en metopas de frisos dóricos itálicos, p.e., de Cassino (Joulia, 1988; lám. XCIII), o galos, p.e. de Nîmes (Ibid.: lám. LXXXIII). 


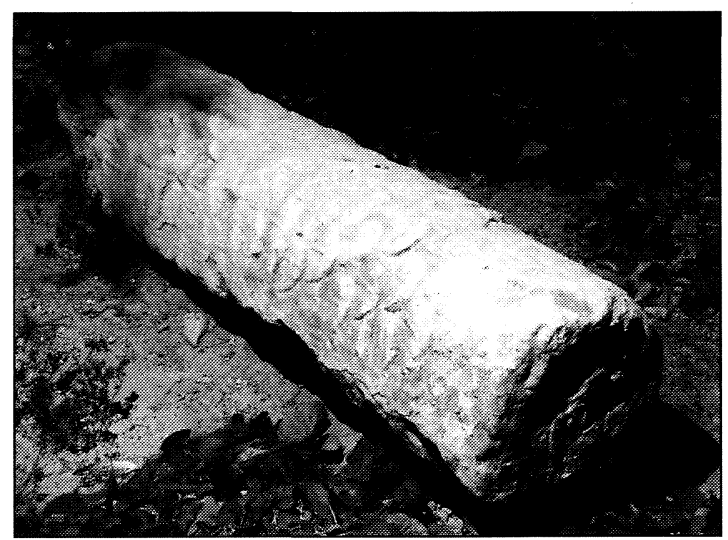

Fig. 33. Pulvino del Museo Arqueológico de Jaén, dado como de procedencia desconocida, pero que apareció en Ossigi («Cerro Alcalá», Jimena de la Frontera, Jaén), en el «cortijo de Caniles». Museo Arqueológico de Jaén.

Fortes, 1990: 214, n 4, fig. 16) (fig. 33). Ahora podemos corroborarlo por la cita contenida en la obra inédita de Enrique Romero de Torres (1914: 1156), ya que a esta pieza - aunque no da fotografía y a pesar de las diferencias en las mediciones- debe con seguridad referirse este autor: «También se conserva delante de la explanada de la casa de Caniles un león de piedra franca de carácter arcaico, varios capiteles y basas y un fuste de columna imitando un tronco de palmera con un anillo ó faja en el centro, cuya altura alcanza á 1,65 centímetros y su diámetro á 0,46. Estos objetos se descubrieron en una era próxima, donde había una línea de sepulturas con restos humanos» ${ }^{50}$.

El pulvino se conserva completo, con balteus central y hojas imbricadas de perfil redondeado y nervio central decorando el cuerpo, y dispone una roseta como decoración en el frente del pulvino, en el centro de un motivo espiraliforme. Si se acepta nuestra hipótesis, es de interés la relación que se establece entre el pulvino y los otros elementos de carácter funerario: el león sepulcral de piedra local y los capiteles y basas, que debieron pertenecer asimismo a los edificios funerarios de una necrópolis

${ }^{50} \mathrm{El}$ manuscrito y las ilustraciones se conservan en el Instituto de Historia del Arte del CSIC en Madrid. El cortijo de Caniles, junto a los de Recena y El Pino - del que procede otro ejemplar que mencionamos a continuación-, aparecen citados por este autor como lugares donde tienen lugar los descubrimientos ossigitanos de principios del siglo XX. Otro león funerario aparecido en tierras de Caniles, junto a un friso sepulcral con el busto de una difunta, asimismo recoge Romero de Torres en su obra (1914: 1156s.) y los hemos dado a conocer en Beltrán Fortes, 2002b: 484ss., figs. 13-14; Baena del Alcázar, Beltrán Fortes, 2002:153s., nos 164-165, láms. LXXVI, 2 y LXXVII, 1. urbana (de forma significativa se dice que había «una línea de sepulturas»).

Otra pieza de forma similar a la anterior se encuentra empotrada en una de las casas de la localidad de Jimena, por lo que sólo se documenta una longitud de $1,31 \mathrm{~m}$, sin conocerse el grosor, aunque asimismo las dimensiones deben ser similares (Beltrán Fortes, 1990: 213, $\mathrm{n}^{\circ}$ 2). La tercera pieza de Ossigi es de un tipo diferente, de menores dimensiones, de $0,24 \mathrm{~m}$ de grosor y conservada sólo en una longitud de $0,50 \mathrm{~m}$, que incluye el balteus, con dos bandas ondulantes en su interior; se conserva en los fondos del Museo Arqueológico de Jaén y se encontró en el «cortijo El Pino» (Beltrán Fortes, 1990: $\left.213, \mathrm{n}^{\circ} 3\right)^{51}$.

De la importante ciudad romana de Castulo (Cazlona, Linares), de donde procede el mayor conjunto de piezas pertenecientes a edificaciones funerarias de época altoimperial (Baena del Alcázar, Beltrán Fortes, 2002: esp. 52 ss.), conocíamos sólo dos ejemplares de pulvinos descontextualizados. Uno de ellos, desaparecido en la actualidad, había sido retallado y reutilizado como cubierta de un sarcófago tardoantiguo de la necrópolis del «olivar de los Patos», en la propia Castulo, sólo reconocible en una fotografía aportada en 1965 en la revista Oretania, sobre descubrimientos castulonenses, pero sin autor ni referencia en el texto (Anónimo, 1965: 159). La otra pieza castulonense, bien conocida - ya que formó parte de la colección de Manuel de Góngora, pasando entre 1869 y 1871 al Museo Arqueológico Nacional (Barril Vicente, 1993: 338s.) -, es una de las más singulares de las aparecidas en Hispania: se trata del fragmento frontal de un coronamiento completo (pulvinos y frontón) y monolítico (fig. 34), con dos pulvinos fragmentados, que asientan sobre un

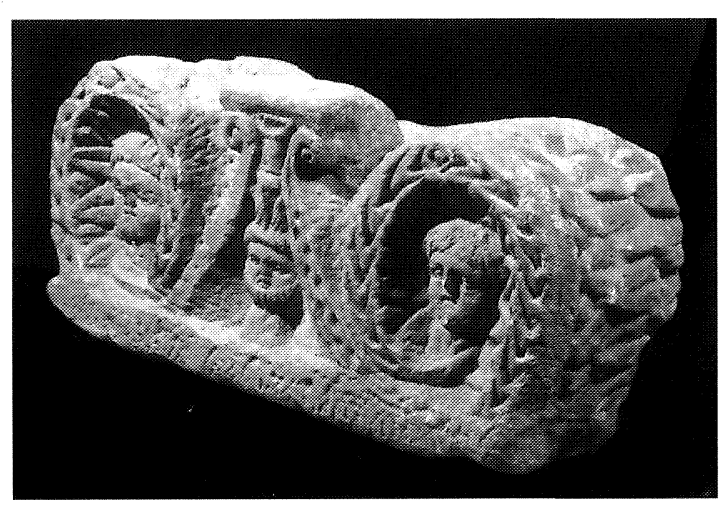

Fig. 34. Coronamiento monolítico de altar de Castulo (Cazlona, Jaén). Museo Arqueológico Nacional de Madrid (Fotografía: Museo)

${ }^{51} \mathrm{Cfr}$. nota anterior 


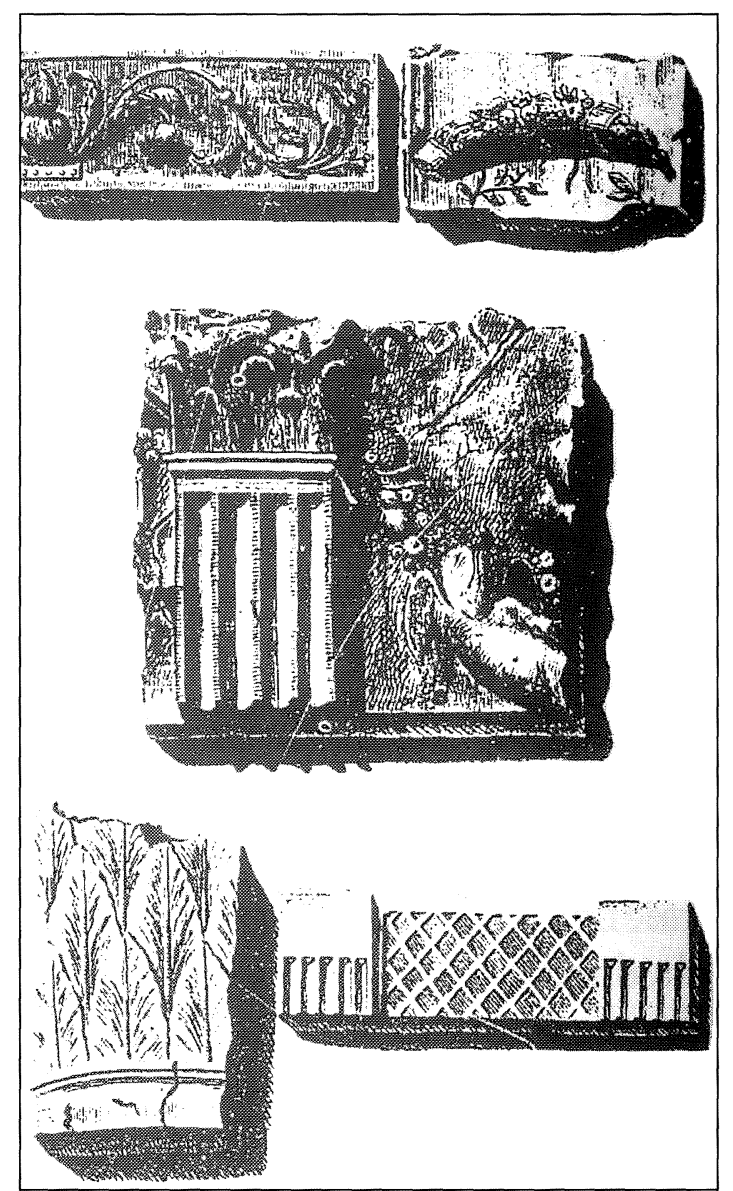

Fig. 35. Dibujo del diario del viaje por Andalucía de F. Pérez Bayer, en 1782, en que se recogen piezas arqueológicas de Castulo (Cazlona, Linares, Jaén), según Pérez Bayer, 1998, 206. Puede reconocerse un fragmento de pulvino en la pieza colocada en la parte inferior izquierda.

zócalo, y con la típica decoración de hojas imbricadas en el cuerpo, pero con dos bustos en el centro de rosetas como decoración en el frente (seguramente la representación de difuntos) ${ }^{52}$; entre los pulvinos se sitúa un frontón decorado con volutas en la parte superior y otro busto masculino en el centro, pero que tiene cuernos y se corona con una especie de altar, seguramente en este caso una divinidad (¿Pan?). Tiene $0,44 \mathrm{~m}$ de altura, $0,93 \mathrm{~m}$ de anchura y 0,375 $\mathrm{m}$ de grosor conservado, y a pesar de que coronaba un monumento funerario en forma de altar de pequeñas dimensiones, el diámetro (algo más de 0,35 m) y la forma de los pulvinos cilíndricos se asimilan a buena parte de los pulvinos que hemos visto y que coronarían verdaderos edificios sepulcrales, por lo

\footnotetext{
${ }^{52}$ A. García y Bellido (1949: $n^{\circ} 311$ ) los identificó como representación del sol y la luna, lo que -aunque no se descarta- nos parece menos plausible.
}

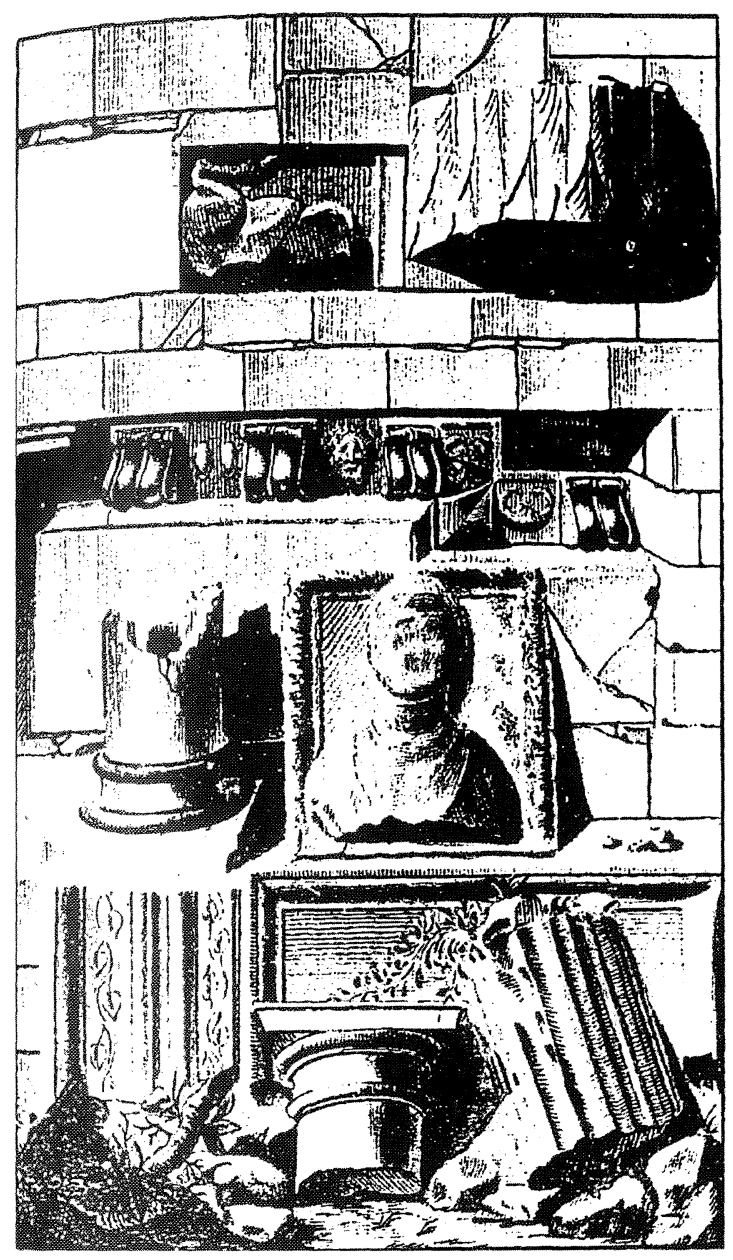

Fig. 36. Idem, según Pérez Bayer, 1998, 207. En este caso el fragmento de pulvino se reconoce en la parte superior derecha.

que supone una adaptación a una forma excepcional, sobre la que volveremos a tratar más adelante.

Otras referencias sirven para aumentar la presencia de pulvinos monumentales en Castulo $^{53}$, como se recoge en algunos de los dibujos que mandara realizar el erudito ilustrado Francisco Pérez Bayer en su visita a las ruinas en 1782, sólo ahora editados (Pérez Bayer, 1998). En efecto, en dos de las láminas de piezas que se conservaban entonces reutiliza-

${ }^{53} \mathrm{Me}$ parece muy posible que la pieza castulonense interpretada como un capitel con decoración de sogueados y puntas triangulares en relieve (según Blázquez, Contreras, Urruela, 1984: 287, $\mathrm{n}^{\circ} 2$, fig. 108), corresponda también en realidad a un fragmento de pulvino, en el que el sogueado corresponda a la decoración del balteus y las puntas sean las hojas que decorarían el cuerpo de la pieza. Aunque se dice que aún entonces se conservaba en el borde del arco de la «Puente Quebrada», en el lado norte, paramento oeste, no he podido verla personalmente, por lo que lo apunto sólo como hipótesis. 
das en las construcciones medievales (sobre todo en una torre árabe y en la ermita de Santa Eufemia) o modernas de los cortijos adyacentes - y hoy están desaparecidas-, se reconoce dos posibles fragmentos de pulvino (Pérez Bayer, 1998: 206 y 207) (figs. 35-36).

De entre los materiales giennenses que dí a conocer en 1990 destacaba un fragmento de pulvino de la colonia de Tucci (Martos), que había aparecido de forma casual en el paraje de Santo Nicacio, en las afueras de la ciudad, bastante deteriorado y con signos de reutilización, pero que evidenciaba un ejemplar de grandes dimensiones, aunque lo conservado era $0,336 \mathrm{~m}$ de altura, $0,54 \mathrm{~m}$ de anchura y $0,44 \mathrm{~m}$ de longitud (Beltrán Fortes, 1990: 214, fig. 17). El frente se decora con una roseta en espiral, de cuatro pétalos de acanto y botón central, en el centro de un motivo espiraliforme, que se desenrolla hacia la izquierda; en el extremo superior se debía decorar con un tallo de media hoja de acanto, en conexión con la prolongación lateral hacia ese lado - ya que correspondía a un pulvino derecho-, mientras que en el espacio inferior izquierdo se ha grabado un cáliz de acanto para cubrir ese espacio libre; al igual que la decoración vegetal del frente, el cuerpo ofrecía un relieve de gran resalte y buena ejecución en la representación de las hojas imbricadas, apuntadas y con nervio central, similares a las que veremos en la pieza de Ilurco. Ahora podemos engrosar el repertorio tuccitano con otro ejemplar inédito de pulvino de excepcionales características, que se conserva en los fondos del Museo Arqueológico de Granada ${ }^{54}$, en donde ingresó como procedente de Martos en 1880 por donación de la Comisión Provincial de Monumentos Históricos y Artísticos granadina, aunque se desconoce cualquier referencia al contexto original de descubrimiento. Se trata de un bloque elaborado en mármol blanco con vetas rojizas, que procede de las canteras de Almadén de la Plata (Sevilla), y, donde a pesar de las fracturas, se reconoce el gran pulvino cilíndrico en la parte izquierda (fig. 37), apoyado sobre el zócalo cuadrangular de base y decorado en el frente con un simple motivo espiraliforme, que se desenrolla hacia la derecha, mientras que en el lateral del cuerpo - escasamente conservadose aprecian las hojas imbricadas, de perfil redondeado en este caso. Aparte de la excepcionalidad del material marmóreo usado, como ya indicamos al tratar de la pieza italicense, es singular la solución dada al alargamiento lateral que la pieza presenta en la parte derecha. Se trata de un bloque cuadrangular,

${ }^{54} \mathrm{~N}^{\circ}$ de inventario 350 (= 1467). Nuestro agradecimiento al Director y cuerpo técnico del Museo Arqueológico de Granada por su ayuda.

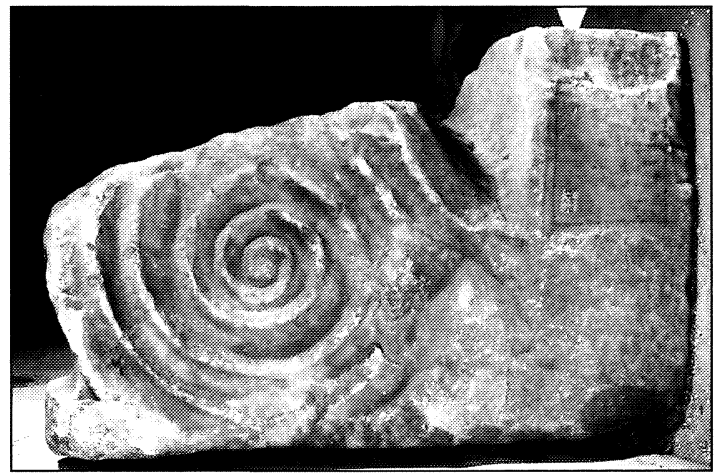

Fig. 37. Pulvino de Tucci (Martos, Jaén). Fondos del Museo Arqueológico de Granada.

de tendencia vertical, liso, pero con un recuadro asimismo rectangular en la parte superior, aunque fracturado en la zona alta; el recuadro, rehundido, se delimita mediante una moldura. Esa disposición apunta a un campo epigráfico, pero no quedan huellas de ninguna inscripción, ni el lugar es apropiado para la colocación de un epígrafe de tan pequeño formato, por lo elevado de la colocación en el mausoleo, que hace poco probable esta opción; cabría pensar en una decoración pintada, pero asimismo es extraña la disposición del soporte. Quizás lo preferible sea pensar en una reutilización o, más bien, un intento de reutilización de la pieza, que, al fin, no llegó a producirse. Es por todo ello un pulvino de gran originalidad morfológica en la disposición del alargamiento lateral y donde se corrobora que, en raras ocasiones, como veíamos en el caso del pulvino italicense, también se utilizó el mármol en la elaboración de este tipo de monumenta sepulcrales hispanorromanos. Debe destacarse la distancia existente entre este lugar y las canteras de Almadén de la Plata, en la sierra sevillana, lo que hace más excepcional el uso de esta pieza en la colonia tuccitana.

En este sector del Alto Guadalquivir se agrega otro nuevo pulvino más de la también colonia Salaria («Úbeda la Vieja» o cortijo de «Doña Aldonza», Úbeda), de donde proceden importantes restos de arquitectura funeraria de época tardorrepublicana y altoimperial, que documentan al menos la existencia de un monumento turriforme con edícula de una familia de Stlaccii, datado en época de Augusto (cfr., especialmente, Beltrán Fortes, Baena del Alcázar, 1996; Baena del Alcázar, Beltrán Fortes, 2002: 46,

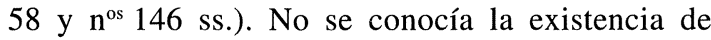
mausoleos en forma de altar con pulvinos, pero sí se corrobora ahora, por esa procedencia de un fragmento de pulvino que formó parte de una colección particular sevillana, del que lamentablemente tam- 


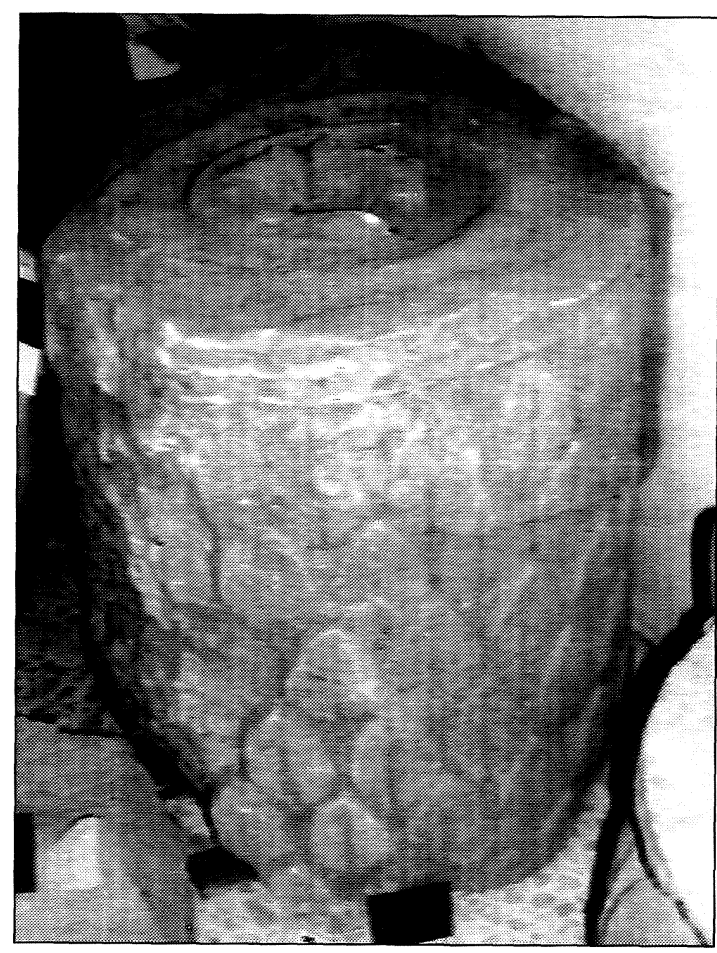

Fig. 38. Pulvino de Salaria («Doña Aldonza», Úbeda, Jaén).Colección particular.

poco tenemos constancia del lugar ni circunstancias exactos de descubrimiento en el yacimiento y sólo lo conocemos mediante una fotografía (fig. 38). Lo conservado corresponde a la parte delantera de un grueso pulvino cilíndrico, de más de $0,40 \mathrm{~m}$ de diámetro, aunque desconocemos las dimensiones exactas, y decorado en el frente con un motivo espiraliforme en cuyo centro se ha colocado una gruesa roseta de cuatro pétalos; el cuerpo dispone las típicas hojas apuntadas, con nervio central e imbricadas, sin adivinarse signos del balteus que iría colocado en el medio.

De los materiales giennenses debemos recordar todavía otra pieza que ya dimos a conocer en 1990, conservada en el Museo de Jaén, aunque de procedencia desconocida, sin que podamos aportar en este caso ninguna hipótesis sobre su origen probable (Beltrán Fortes, 1990: 215, n 7). Aunque elaborada también en caliza, presenta una forma diferente de la de los otros pulvinos analizados para el Alto Guadalquivir, tanto por su forma y decoración, cuanto por sus pequeñas dimensiones. Así, lo conservado corresponde al balteus y a la mitad completa de uno de los cuerpos del pulvino, que presenta no una forma cilíndrica, sino con perfiles curvados en forma de balaustrada, con el cuerpo recorrido con dos ban- das imbricadas de largas hojas apuntadas, y una tercera rellenando el extremo. El frente sí se decora con un motivo bien documentado, una roseta en el centro de un motivo espiraliforme, que se continuaría por un alargamiento lateral del pulvino, que debió ocupar la parte derecha del coronamiento. Mide $0,15 \mathrm{~m}$ de diámetro y $0,45 \mathrm{~m}$ de longitud, por lo que el resultado final sería una longitud de 0,75-0,80 m., lo que asegura esa excepcionalidad a la que nos hemos referido dentro de la serie de pulvinos hispanorromanos; quizás pueda tratarse - como asimismo indicamos para los pulvinos valencianos- de coronamientos de arae ossuariae.

\section{El resto de Andalucía Oriental: Málaga, Gra- nada y Almería}

Para terminar este amplio recorrido debemos detenernos ya en el resto de Andalucía oriental, a caballo entre el extremo oriental de la provincia Baetica y el sureste de la Tarraconensis, en las actuales provincias de Málaga, Granada y Almería. De las cuatro piezas que podemos catalogar ahora, dos de ellas las dimos a conocer ya en 1990 y otras dos son nuevas, lo que amplía también en este sector peninsular el área de uso de los mausoleos en forma de altar.

La primera procede de la ciudad romana de $O s$ qua («cerro del León», Villanueva del Rosario, Málaga) (Beltrán Fortes, 1990: 216, nº 8) y es formalmente muy parecida al anterior ejemplar salariense; un grueso pulvino cilíndrico (de $0,60 \mathrm{~m}$ de diámetro y $0,82 \mathrm{~m}$ de longitud), elaborado en caliza, con hojas imbricadas en el cuerpo, con el inicio del balteus en uno de los extremos (por lo que la pieza completa no alcanzaría los dos metros) y en el frente una roseta de cinco pétalos en el centro de un motivo espiraliforme. Está roto por un lateral, por lo que se desconoce si presentaba algún alargamiento lateral o era completamente cilíndrico, y asimismo en una zona no se ha ejecutado el relieve, lo que indica que era esa parte la que apoyaba sobre el monumento, correspondiente a un pulvino derecho.

El segundo ejemplar ya conocido debe proceder de Ilurco (Pinos-Puente, Granada), aunque se conserva en la finca Soto de Roma, en el término municipal de Íllora. En este caso nos encontramos con un pulvino derecho completo (fig. 39), que apoya sobre un pequeño zócalo cuadrangular y dispone un pequeño alargamiento lateral, decorado en su frente, como ocurriera en el caso ya analizado del ejemplar de Las Cabezas, por un motivo espiraliforme que presenta un rostro de cabello corto y raya en medio 


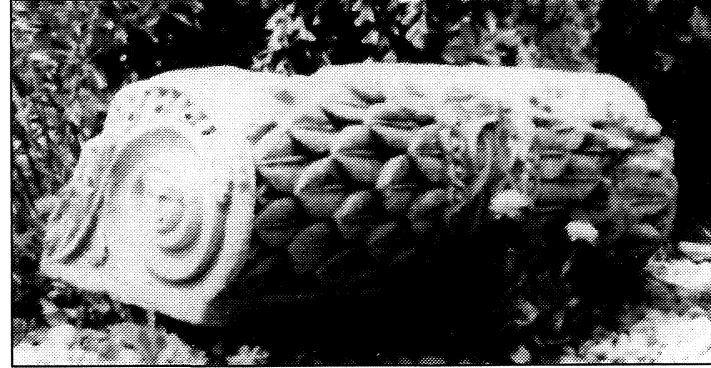

Fig. 39. Pulvino de Ilurco (Pinos-Puente, Granada), que se conserva en la finca Soto de Roma (Íllora, Granada).

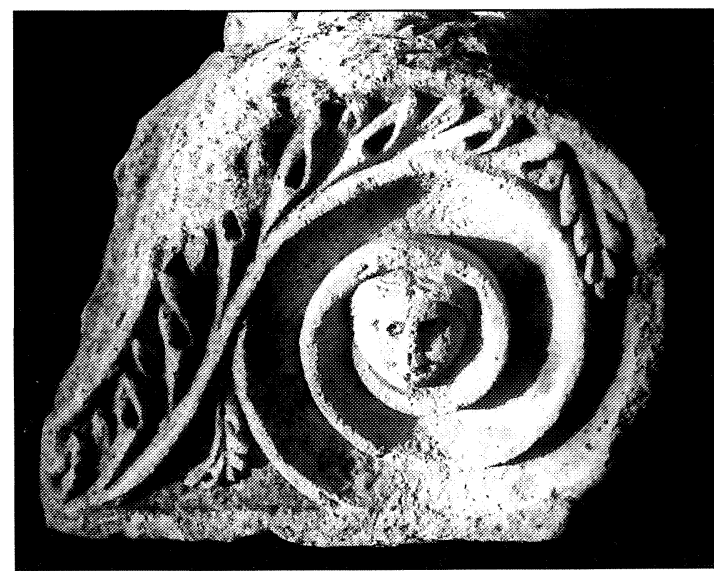

Fig. 40. Idem. Detalle del frente.

en el centro del pulvino y hojas de acanto en la parte superior del tallo de la espiral (fig. 40); el cuerpo se decora con las típicas bandas de hojas imbricadas, a ambos lados de un balteus central que se presenta el motivo del nudo hercúleo. La pieza tiene $0,35 \mathrm{~m}$ de diámetro y sólo 1,14 m de longitud, que sería el grosor total del monumento funerario que coronaría.

Como de procedencia desconocida se conserva en los fondos del Museo Arqueológico Provincial de Granada una pieza fragmentada pero claramente identificada también con un pulvino por el tipo de decoración del cuerpo, con hojas apuntadas e imbricadas, de grueso nervio central, y parte de la del frente, fragmentada y bastante deteriorada, pero donde parece adivinarse asimismo un motivo espiraliforme. Está elaborado en caliza, y aunque - como se ha dicho- no se conoce el lugar exacto de descubrimiento, hemos de pensar en principio que proceda de los actuales territorios granadinos o, en todo caso, de Andalucía oriental.

Otro fragmento de pulvino procede de Vélez-Rubio (Almería), donde apareció en las afueras de la localidad esta misma localidad almeriense, en el lugar de «Las Peñicas», en un contexto de reutiliza-

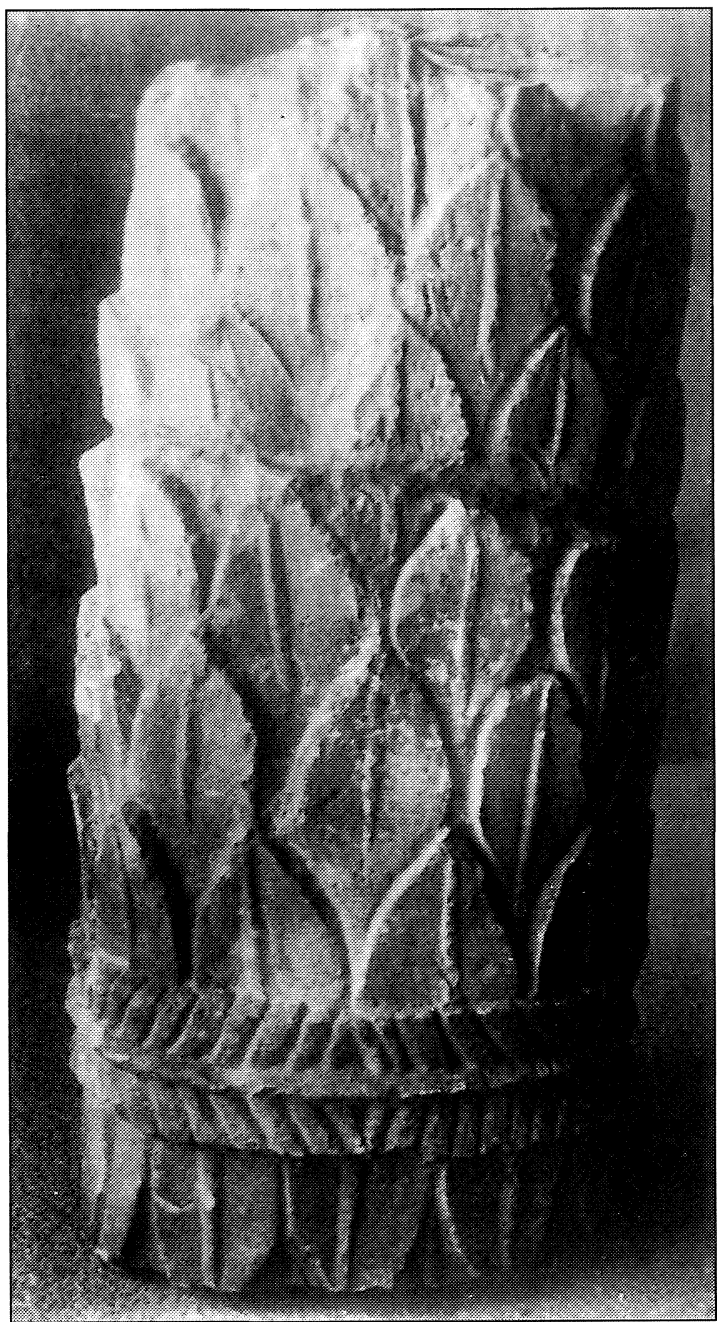

Fig. 41. Pulvino de Vélez-Rubio (Almería). Museo Comarcal Velezano «Miguel Guirao».

ción, conservándose hoy día en el Museo Comarcal Velezano «Miguel Guirao» ${ }^{55}$ (Martínez García, 1986: 29-40) (fig. 41). Se trata de un fragmento de pulvino elaborado en arenisca local, que mide 0,40 $\mathrm{m}$ de altura $\times 0,40 \mathrm{~m}$ de anchura $\times 82 \mathrm{~m}$ de longitud conservada, presentando una de las caras totalmente plana y sin decoración, ya que se asentaría sobre ella en la parte superior del monumento; el resto se ha tallado buscando la original forma cilíndrica y se decora con las típicas hojas imbricadas, a partir del balteus, simplemente señalado con un motivo de espina contrapuesto en la parte superior del eje central. Conserva sólo una línea de hojas a uno de los

${ }^{55} \mathrm{Mi}$ agradecimiento al director del Museo por las indicaciones correspondientes. Erróneamente se expone entre las piezas de época visigoda. También agradezco a J. C. Vera (Univ. de Huelva) haber llamado mi atención sobre la pieza. 
lados del balteus y seis líneas superpuestas al otro lado, pero sin ofrecer el extremo final del pulvino, por lo que se debió unir a otro bloque por este lado, aunque desconocemos las dimensiones finales que tendría la pieza.

\section{ALGUNAS NOTAS A MANERA DE CON- CLUSIÓN}

La amplitud que tiene el apartado anterior, en que se revisan los materiales de estudio, obliga a una mayor brevedad en este segundo apartado, por lo que no voy a insistir demasiado en los aspectos generales, para lo que remito a las obras citadas al principio, haciendo sólo una referencia sucinta a las cuestiones que me parecen de mayor interés o, cuando menos, más problemáticas. Éstas son, a mi juicio: la cronología, teniendo en cuenta el origen y período de uso en Hispania, la tipología y, finalmente, los ámbitos de uso dentro del marco general de desarrollo del mundo funerario hispanorromano a fines de la República y durante el Alto Imperio. Es obvio que otras importantes facetas, como los rituales asociados a esta arquitectura funeraria o la clientela hispanorromana deben quedar en suspenso hasta que tengamos un conocimiento mucho más preciso de los contextos arqueológicos o de inscripciones asociadas a estos monumentos.

\section{LA CRONOLOGÍA DE ORIGEN Y USO}

Es bastante problemâtico responder a la cuestión de la fecha de origen y uso de estos monumenta en los territorios hispanos debido al gran desconocimiento de contextos arqueológicos adecuados, amén de la dificultad de extraer conclusiones cronológicas de las características morfológicas o estilísticas. La mayor parte de las piezas que hemos analizado corresponden sólo a los elementos de coronamiento (los pulvinos) y, en su mayoría, han sido encontradas de forma casual en diversos momentos y se encuentran formando parte de fondos de museos o colecciones arqueológicas, o bien ya fueron reutilizadas en la Tardoantigüedad o el Medievo y, consecuentemente, los contextos arqueológicos de aparición tampoco nos informan bastante sobre su uso original. Son ilustrativas en ese sentido las amplias series de piezas procedentes del área catalana, que fueron conocidas en su totalidad reaprovechadas en la necrópolis cristiana de Tarragona o en los rellenos de la muralla tardorromana de Barcelona (Balil Illana, 1961: esp. 90 ss.), o bien de Mérida e Idanha-a-
Velha, asimismo reaprovechadas en construcciones medievales, o bien las de Segobriga, de las que no se conoce las circunstancias exactas de descubrimiento. Los restos de los dos únicos monumentos parcialmente recuperados in situ y como fruto de excavaciones arqueológicas recientes son los de $\mathrm{La}$ Calerilla de Requena - como se dijo en su lugaral que su excavadora le asigna una fecha de construcción de mediados del siglo I d.C. (Martínez Valle, 1995), y — si se acepta nuestra hipótesis - los de El Sotillo de Alfaro, que se dataría en época augustea (Hernández Vera y otros, 1999).

La cronología que se ha dado al resto de los materiales hispanos - cuando se les ha dado algunaha sido muy diversa y condicionada por factores como la correcta interpretación del material, los criterios estilísticos aplicados o, como marco general, la propia interpretación del proceso de asimilación de formas romanas en los diversos lugares. Así también lo habíamos indicado, como resultado de que «...nos movemos dentro de obras que responden al concepto de 'plástica provincial', en determinadas parcelas paralelizable con el de «arte plebeyo», que presenta unos ámbitos de influencia y vías de desarrollo diferentes de los del arte oficial, y que utilizan materiales locales (calizas y areniscas, en este caso), cuyas características particulares multiplican, por imperativos técnicos, las alteraciones de los prototipos originales» (Beltrán Fortes, 1990: 209). Lógicamente, el conjunto de los pulvinos catalanes ha sido sobre el que se ha tratado más, tanto por la cantidad y morfología de las piezas (con rica decoración en relieve), como por su temprana identificación como coronamientos de monumentales altares funerarios. A. García y Bellido aplicó erróneos criterios estilísticos, al considerar los relieves de época tardía como exponente de su poca calidad, y los fechó en el siglo III d.C. (García y Bellido, 1949: 307). Por el contrario, A. Balil añadió todo el siglo II d.C., hasta los inicios o el primer tercio del siglo III d.C. (Balil Illana, 1964: 153 s.), aunque posteriormente situó la fecha de inicio en época flavia (Balil Illana, 1979). En fecha más reciente, G. Gamer indicó una datación más precisa, considerando que todos los ejemplares se databan a lo largo del siglo II d.C. y negando su uso en la centuria anterior (Gamer, 1989: 125), mientras que M. Blech (1993: 334 s.) lo situaba de nuevo en la segunda mitad del siglo I d.C. Por el contrario, yo mismo ya expuse la hipótesis de que «...parece lógico, a falta de datos estratigráficos, plantear la recepción de tales modelos en Cataluña ya en época julio-claudia, si consideramos esa directa relación que une el territorio medioitálico y la costa mediterránea hispana...»(Bel- 
trán Fortes, 1990: 196). Esa misma idea de una datación temprana, ya desde época augustea y julioclaudia, exponen H. von Hesberg (1993: 166s.), para quien la serie comienza en época augustea pero los ejemplares más tardíos ocuparían hasta el siglo II d.C. ${ }^{56}$, e I. Rodá (2000), en su estudio comparativo entre la escultura del sur de la Narbonense y del norte de Hispania Citerior. Esta última autora indica de forma adecuada que los pulvinos barcinonenses con gorgoneion debían datarse en su inicio «...en época augustea o, quizás, julio-claudia inicial, relacionando estas estructuras con estamentos militares, según también las constataciones hechas por J.-Cl. Joulia para el conjunto narbonense...» (Rodá, 2000: 179; según Joulia, 1988).

Algo similar ha ocurrido, grosso modo, con la cronología dada al resto de los materiales hispanos, en los que se ha basculado desde una datación tardía en el siglo III d.C., hasta una de comienzos del siglo II d.C. o época flavia y, finalmente, otra mayoritaria del siglo I d.C., centrada sobre todo en época julio-claudia e incluso época augustea. Ejemplo evidente nos los ofrecen los materiales andaluces del Alto Guadalquivir, dentro del conjunto más amplio de los relieves decorativos de edificios sepulcrales, que también pasaron de ser datados desde el siglo III d.C. hasta época flavia (Beltrán Fortes, 1990) y, ahora, especialmente en época julio-claudia, situando los momentos de inicio en general en época augustea (Baena del Alcázar, Beltrán Fortes, 2002: 52 ss., con bibliografía anterior). Precisamente, a pesar de las alteraciones posteriores, que hacían que uno de los pulvinos cordobeses fuera reutilizado en un muro medieval en un solar de la c/ Adarve, situado al lado de la torre de la Malmuerta (supra fig. 27), el resto de los materiales romanos aparecidos en ese ambiente ${ }^{57}$ apuntarían a un momento augusteo (Vaquerizo Gil, 2001: 144). Fuera de Andalucía otros ambientes arqueológicos asimismo abogan por una datación augustea en algunos casos. Así ocurre en el caso citado de los materiales de Graccurris, si consideramos que el pulvino coronaría el posible mausoleo, que es datado en época augustea (Hernández Vera y otros, 1999: 260), a lo que en efecto puede apuntar el estilo y forma del ca-

56 En ello sigue la datación de G. Gamer de la representación de un retrato femenino en el centro de una roseta con el peinado de Faustina la Menor que decora el frente de un pulvino tarraconense (Gamer, 1989: 125, T 80).

${ }^{57}$ En ese ámbito había asimismo aparecido el ara ossuaria de Abullia Nigella (CIL II $2255=$ CIL II ${ }^{2} / 7$, 397), que se fecha por datación consular en el año 19 a.C., así como la inscripción funeraria de su patrono N. Abullius Chrestus (CIL II $2254=\mathrm{CIL} \mathrm{II}^{2} / 7,396$ ), «...que evidentemente formaba parte de un mausoleo o al menos de un recinto sepulcral de cierta envergadura» (Stylow, 1995: 224, nota 33). Cfr., además, Vaquerizo Gil, 2000: 192. pitel conservado. O en los pulvinos graníticos de $\mathrm{Au}$ gusta Emerita, si tenemos en cuenta que el uso del material apunta a los primeros momentos de la colonia augustea (Beltrán Fortes, Baena del Alcázar, 1996a: 105ss.; Nogales Basarrate, en Nogales Basarrate, Márquez Pérez, 2002: 123).

Es también normal que no se les haya dado dataciones precisas a otros pulvinos y sus monumentos correspondientes (dejando aparte los ejemplares andaluces, con la problemática que ya hemos referido, podemos citar los casos del mausoleo de Iglesuela del Cid, o los pulvinos de Navarra, de Idanha-a-Velha o Esparragosa de la Serena) o se hayan ofrecido genéricas cronologías a lo largo del siglo I d.C. (casos de los ejemplares de Dehesa de los Baños de Chiprana), que se han centrado en otros casos en la época julioclaudia (como los ejemplares de Segobriga y buena parte de los ejemplares andaluces). También se han dado en ocasiones fechas más recientes, como ocurre, por ejemplo, con los dos pulvinos de Vareia, datados en un período amplio que ocupa desde la segunda mitad del siglo I d.C. y el siglo II d.C., aunque ya expresamos más arriba nuestras dudas. Es posible que la diversidad formal que ofrecen los coronamientos con pulvinos y frontones de la zona valenciana (Valencia, Liria, Benifaró de les Valls) justifique su cronología durante el siglo II d.C., como ha ocurrido para algunos pulvinos catalanes o hemos asignado al pulvino conocido ahora de Italica. En resumen, las dataciones indicadas caracterizan un fenómeno que arranca cuando menos de época augustea y que tiene su máximo desarrollo durante el siglo I d.C. - especialmente en su primera mitad-, con una perduración todavía en la centuria siguiente (algunos ejemplares de Barcelona, de la zona de Valencia y de Italica). No obstante, la mayor parte de las dataciones - como se decía - responde sobre todo a criterios estilísticos o formales que quizás deberán sufrir variaciones en el futuro.

Según se ha destacado en algunas ocasiones, el uso de materiales locales no marmóreos apunta a un momento temprano en la construcción de aquellos edificios que coronaban los pulvinos que documentamos, como ocurre en el caso del granito en los pulvinos emeritenses, relacionados con los primeros momentos de la fundación colonial (Beltrán Fortes, Baena del Alcázar, 1996a; Nogales Basarrate, Márquez Pérez, 2002). Sin embargo, también hay que tener en cuenta el peso de la tradición del empleo de piedras no marmóreas tanto en el artesanado romano-itálico cuanto en el de tradición hispana prerromana que conduciría a un proceso de perduración del uso de esos materiales de forma prolongada en algunos casos, como hemos destacado, por ejemplo, 
para el caso de las ciudades del alto Guadalquivir, frente a otros centros como el mismo de la colonia Patricia (Beltrán Fortes, 2002a: 254s.), donde los estudios de H. von Hesberg (1996: 158ss.) y C. Márquez (1998: 144ss.) han demostrado que ya desde mediados del siglo I d.C. en los edificios sepulcrales cordobeses se emplea profusamente el mármol para la elaboración de elementos con ornamentación - a pesar de la ausencia de canteras en el entorno próximo-, que siguen directamente modelos de la Península Itálica, frente a otras zonas, como la catalana, que se vincula más a los círculos artesanales de la Narbonensis ${ }^{58}$. Ello justificaría que se siga empleando calizas y areniscas locales durante todo el siglo I d.C. y parte de la centuria siguiente, si tenemos en cuenta el material en que fueron elaborados los correspondientes pulvinos, con las excepciones ya citadas de los ejemplares de Italica y Tucci, en Andalucía, y Manresa, en Cataluña.

\section{LA TIPOLOGÍA}

\section{Hipótesis generales}

Por razones obvias, derivadas de que sólo hasta fechas relativamente recientes el tipo sólo era identificado en el área catalán de Tarragona y Barcelona, los ensayos de restitución se habían centrado en ese conjunto catalán y, para el resto peninsular, sólo tenemos hipótesis planteadas en estos últimos años. Ya desde los comienzos del siglo XX, J. Puig i Cadafalch planteó la hipótesis de que ciertos basamentos identificados en la necrópolis cristiana de Tarragona correspondieran a bases de altares monumentales coronados por pulvinos (Puig i Cadafalch y otros, 1908: 144 y figs. 174-176) (supra fig. 6), aunque $H$. von Hesberg aboga mejor por una restitución de un edificio de varios pisos (von Hesberg, 1993: 159 y fig. 78, a). También nos hemos referido supra a las reconstrucciones que existieron en el Museo de la Ciudad y en el Museo Arqueológico de Barcelona (supra figs. 4-5 y 8, que sigue una de las anteriores), donde se había optado por un simple cuerpo de opus quadratum con molduras en la base y el coronamiento, epígrafe en el frente ${ }^{59}$ y corona-

${ }^{58}$ Vid. Rodá de Llanza, 2000. Sobre las características técnicas de la serie giennense, en algunos casos similares a la catalana (por ejemplo, en el uso en ocasiones del contorno reexcavado en los relieves), cfr., ahora, Beltrán Fortes, Baena del Alcázar, 2002.

${ }^{59}$ Mientras en uno se situaba una placa rectangular en el centro del frente del cuerpo, en otro la inscripción estaba separada por una moldura. Referencias a los epígrafes en Bali Illana, 1979.

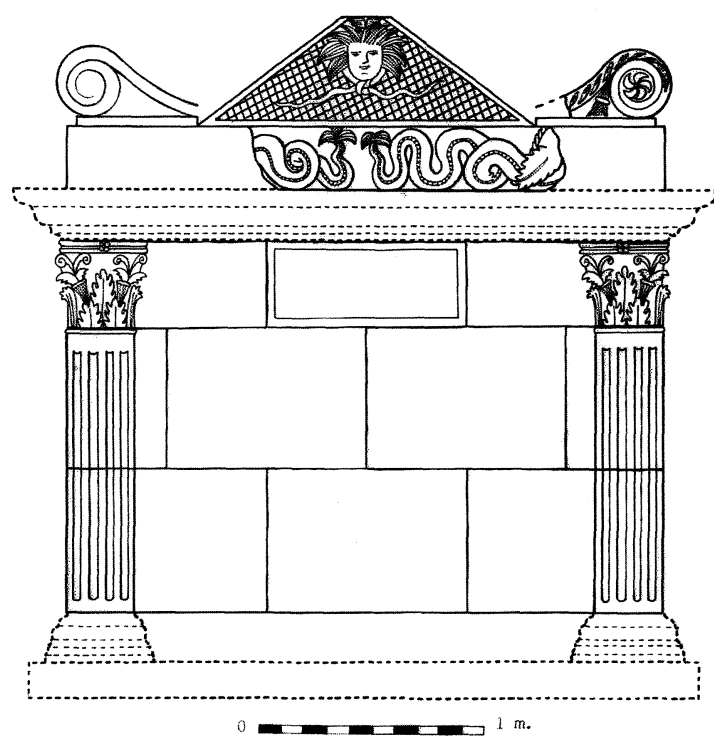

Fig. 42. Restitución ideal del frente y lateral de un mausoleo del Alto Guadalquivir, según Beltrán Fortes, 1990, fig. 13.

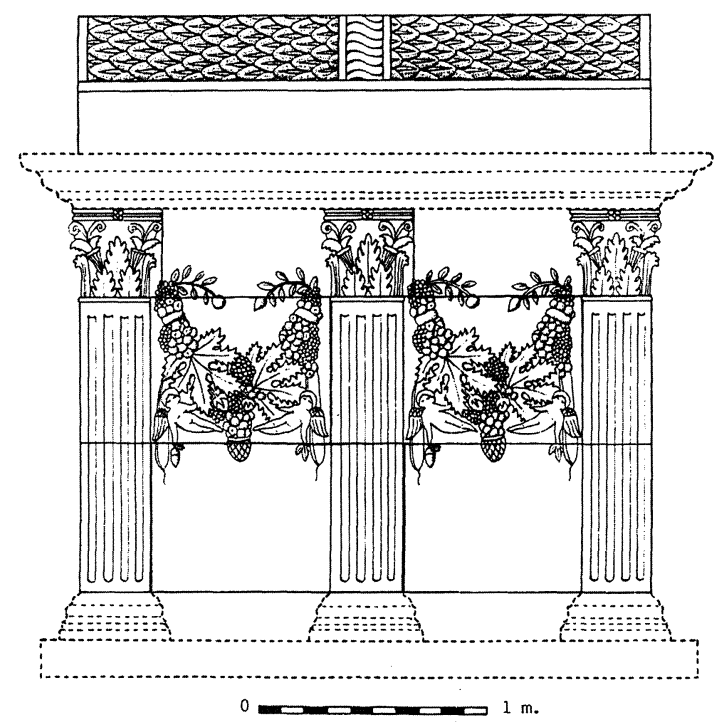

Fig. 43. Idem. Vista lateral, según Beltrán Fortes, 1990, fig. 14 .

miento, respectivamente, de pulvinos cilíndricos y con alargamiento lateral, aunque en este segundo caso se colocó de forma ideal una especie de frontón curvo sin solución de continuidad desde los dos citados alargamientos laterales. Debe tenerse en cuenta que tales reconstrucciones tenían «finalidades puramente expositivas» (Balil Illana, 1964: $117)$, sin tener constancia de que los epígrafes asociados pertenecieran realmente a monumentos de 


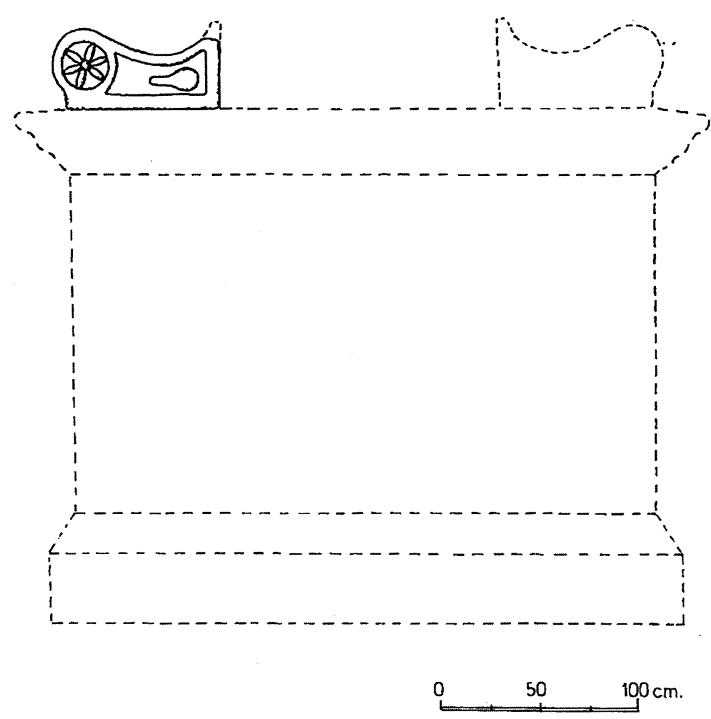

Fig. 44. Restitución ideal de un mausoleo con pulvinos de Augusta Emerita, según Beltrán Fortes, Baena del Alcázar. 1996a: 108 , fig. 2.

este tipo, por lo que han sido ya desmontadas de sus lugares de exposición museística en los tres casos.

Cuando estudié en 1990 la serie de pulvinos conocidos entonces en Andalucía, a pesar de las muchas dudas y la improbabilidad de la exactitud total del resultado final, me pareció oportuno llevar a cabo un dibujo de restitución (Beltrán Fortes, 1990: figs. 13-14) (figs. 42-43), que incorporaba diversos elementos en la decoración exterior del cuerpo (pilastras y guirnaldas) y del coronamiento (frontones entre pulvinos), pero destacando el carácter puramente hipotético que tenía y los problemas que planteaba en la restitución del coronamiento y la decoración del cuerpo (aunque sobre ello volveremos en los dos apartados siguientes). En estos últimos años, se han sucedido otras propuestas, más o menos desarrolladas, en función de los materiales disponibles, como las de los monumentos citados de Requena, Córdoba o Mérida. En primer lugar, destaca la llevada a cabo por A. Martínez del mausoleo de La Calerilla en Requena (Martínez Valle, 1995: 259ss.), por la mayor abundancia de elementos que aporta en las diversas variantes del frente y lateral (supra figs. 1416), mientras que son más genéricas las realizadas para el caso de Augusta Emerita por J. Beltrán y L. Baena (1996a) (fig. 44) y T. Nogales (2002: 125, fig. 3) (fig. 45) y, para el caso de Corduba, por D. Vaquerizo (2001a: 146, fig. 11, y 2002: 188, fig. 22) (supra fig. 28). La última que ha sido dada a conocer corresponde al mausoleo en forma de altar de Las Eras de Ontur (Abad Casal, Abascal Palazón, Sanz Gamo, 2002: fig. 12) (fig. 46).
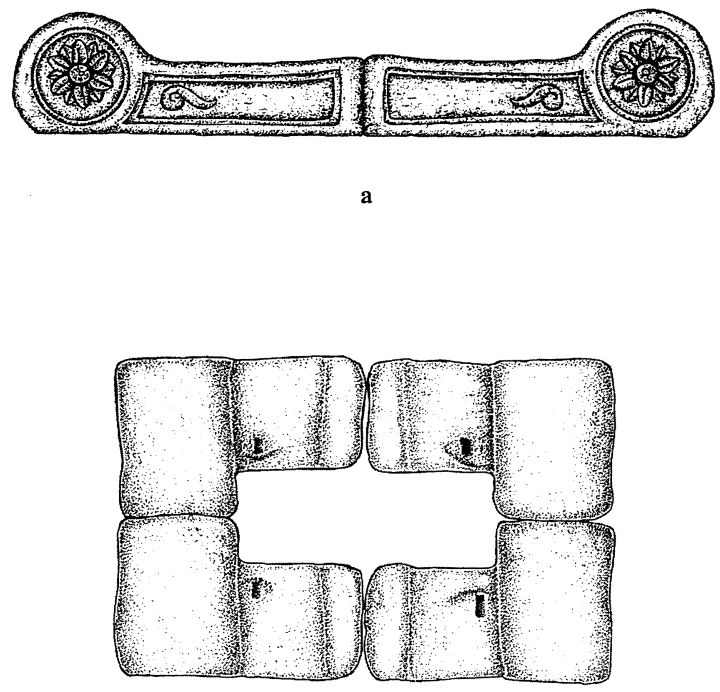

b

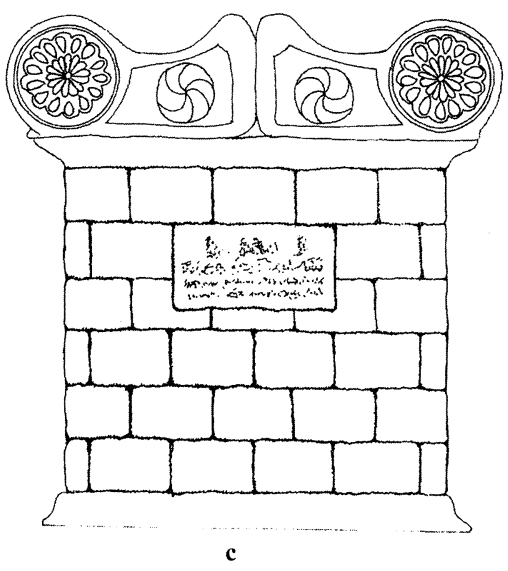

Fig. 45. Nuevas propuestas de colocación de los pulvinos de Augusta Emerita, según Nogales Basarrate, en Nogales Basarrate, Márquez Pérez, 2002: 125, fig. 3.

2. El desarrollo del cuerpo inferior y el coronamiento

Parece obvio que la serie de pulvinos hispanorromanos coronaron monumenta sepulcrales de planta cuadrangular y, seguramente, de opus quadratum. Dentro de los límites que imponen el número de piezas conocidas y su carácter fragmentario, la diversidad de tamaños que traducen los pulvinos indica que, en ocasiones, el cuerpo conformaría la propia cámara funeraria de amplias dimensiones, a cuyo interior se podría acceder, mientras que en los casos de menores dimensiones el cuerpo debió ser macizo, sirviendo o bien de coronamiento de la cámara propiamente dicha (uno de los modelos ya documenta- 


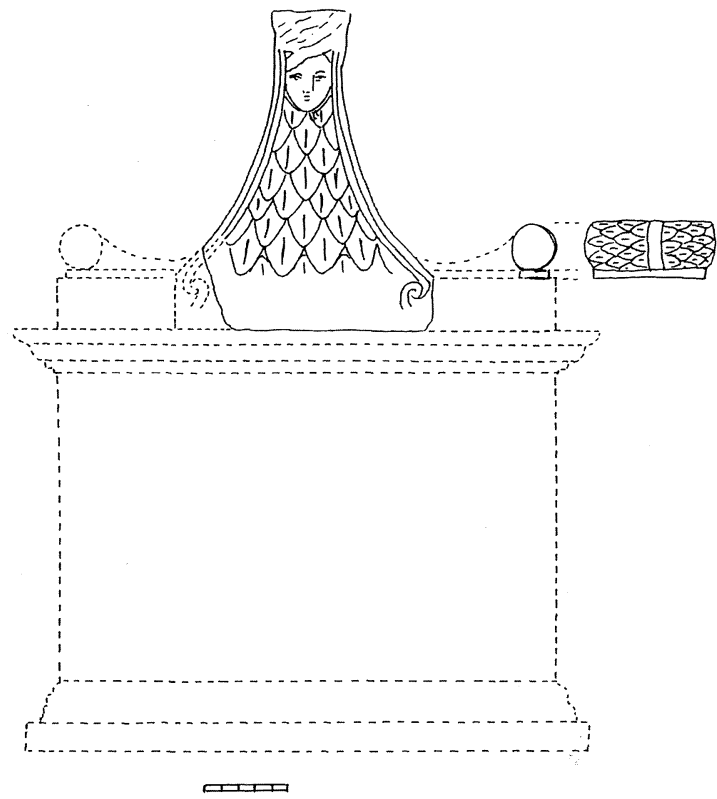

Fig. 46. Restitución ideal del mausoleo en forma de altar de Las Eras de Ontur, según Abad Casal, Abascal Palazón, Sanz Gamo, 2002, fig. 12.

dos en Italia, que citamos al principio), o bien constituyó una verdadera ara ossuaria monumental.

Elemento a tener en cuenta lo supone la decoración que presentaba el cuerpo al exterior, teniendo en cuenta los restos conservados, que son escasos, y los esquemas conocidos para otros territorios itálicos y provincias occidentales. Es cierto que el cuerpo del mausoleo en forma de altar puede aparecer sin decoración, según parece advertirse, por ejemplo, en el resto de paramento del monumentum de La Iglesuela del Cid, conservado parcialmente in situ, o en las hipotéticas restituciones citadas de Corduba, Emerita u Ontur (supra figs. 28, 44-45 y 46, respectivamente), pero, no debemos olvidar que los monumentos de menores dimensiones con friso dórico también se podían coronar con pulvinos (Torelli, 1968: 32 ss.; cfr., además, Joulia, 1988). Además, otros ejemplos nos aclaran que o bien podían existir otros relieves complementarios en el caso de monumentos con friso dórico, o bien se podía producir la sustitución de éste por otros tipos de frisos. Así se documenta en monumentos de la uia Appia, como ocurre respectivamente en las llamadas «tumba dórica» — con relieves complementarios-y en la «tumba con guirnaldas» — con un friso de erotes que sostienen guirnaldas- (se reproducen en Gros, 2001: 393, figs. 448 y 449, respectivamente).

En este sentido nos centraremos de nuevo, en primer lugar, en los materiales catalanes. Frente a los esquemas sin decoración relivaria que ofrecían los ejemplos restituidos en los dos museos barceloneses citados, sólo con la inclusión en el frente de los epígrafes, han destacado A. Balil e I. Rodá esa posibilidad de asociación de frisos dóricos para los ejemplares catalanes ${ }^{60}$, apuntando también las posibles relaciones de esa serie con alguna de las de Neumagen ${ }^{61}$. Es además plausible que la riqueza de relieves que presentan los pulvinos catalanes, tanto en el frente del cilindro (gorgoneia) como del alargamiento lateral (en ocasiones también con escenas figuradas), se correspondiera con la presencia de relieves en el cuerpo de algunos monumentos, bien mediante frisos o bien incluso mediante otros tipos de relieves. El problema de aseverar ese binomio pulvinos / friso dórico para los ejemplares catalanes se deriva de la misma descontextualización de las piezas y la falta de correspondencia entre los hallazgos de ambos tipos de piezas, lo que es extensible a otros ámbitos peninsulares. Para éstos sólo contamos ahora con un caso en que se produce esa coincidencia; así, de Vareia proceden un fragmento de friso dórico y dos pulvinos de diversa tipología, pero que no aparecieron en las mismas circunstancias y que han sido considerados por su editor de monumentos y fechas diversos ${ }^{62}$. Además, no son muy abundantes los testimonios hispanorromanos de frisos dóricos, que se concentran en la costa catalana y levantina y no afectan en demasía al resto del territorio hispano, como quedó en evidencia en el estudio de M. A. Gutiérrez Behemerid (1990: 205 ss.). A los recopilados entonces sólo podemos sumar ahora, aparte del citado fragmento originario de Vareia, un nuevo fragmento inédito procedente del ámbito territorial sevillano del término municipal de

${ }^{60}$ A. Balil matizaba que «...se les considera asociados con los 'monumentos de friso dórico'. Sin embargo, no existe correspondencia entre los hallazgos, en número, de gorgoneia y frisos dóricos. Quizás estos últimos estuvieran asociados sólo al tipo con plutei exentos, decorados también con gorgonas» (Balil Illana, 1988, 31). Aunque en el caso de la tumba de $M$. Porcius, en Pompeya, en que la estructura con friso dórico se corona con pulvinos, éstos también tienen un ligero alargamiento lateral (se reproduce en Gros, 2001: 394, fig. 451). También I. Rodá (2000: 178) ha dicho que «... por lo que a la tipología ... de los monumentos barcinonenses de friso esculpido respecta -y entre ellos, los dóricos-, podríamos sumarnos también a las hipótesis de restitución de altares monumentales en forma de dado que se relacionarian en Barcino con los pulvini con cabezas de Gorgona, excluyendo una pretendida pertenencia a edificios teatrales...».

${ }^{61}$ Sobre esas relaciones formales y estilísticas de algunas piezas de este importante conjunto de la Gallia Belgica con los territorios hispanos incidimos asimismo nosotros (Beltrán Fortes, 1990: 192ss.), si bien también hemos indicado que posiblemente haya que alterar las dataciones de inicio en la primera mitad del siglo II d.C. (von Massow, 1932), al menos a mediados del siglo I d.C., según Beltrán Fortes, 1991 b.

${ }^{62}$ Espinosa, 1996: 439. Cfr., no obstante, lo dicho anteriormente sobre estas piezas. 
Écija (cortijo de El Guijo) ${ }^{63}$, que, junto al ejemplar de Castulo (ahora, Baena del Alcázar, Beltrán Fortes, 2002: 109, no 79, lám. XXXIX), suponen los dos únicos ejemplares conocidos de Andalucía, precisamente donde se sitúa una de las mayores concentraciones de pulvinos monumentales. Tampoco - por lo que sabemos- se documenta la existencia de frisos dóricos en lugares de alta concentración de pulvinos, como Segobriga, Augusta Emerita o Egitania.

Nosotros habíamos observado que en la arquitectura funeraria romana del Alto Guadalquivir el friso dórico — sólo testimoniado en el citado fragmento castulonense- se había sustituido por otros tipos de frisos: especialmente los de roleos acantiformes y los que denominamos como de metopas alternas, en los que en lugar del triglifo se colocaba otro motivo que se repetía de forma alterna (especialmente, en unos casos la esvástica, en otros la roseta y la máscara), y en los que se incluían también las placas epigráficas (Beltrán Fortes, Baena del Alcázar, 1996: 67 ss.; Baena del Alcázar, Beltrán Fortes, 2002: 57 ss.). Es por ello plausible que fueran frisos de estas categorías los que se colocaran en la parte alta del cuerpo de algunos de los monumentos en forma de altar — los de dimensiones mayores, en función de los tamaños de los frisos, pero asimismo apropiados para otros tipos de mausoleos turriformes-. Fuera del territorio andaluz la presencia de un friso epigráfico no dórico la tenemos constatada en el ya citado mausoleo de La Calerilla de Requena: en efecto, se trataría de un friso epigráfico en el frente, sostenido por erotes en los extremos, y con metopas decoradas en los laterales (supra figs. 1417). Este mismo ejemplar introduce nuevas posibilidades en las decoraciones en relieve de los mausoleos hispanorromanos en forma de altar, ya que asimismo dispone bajo el friso citado de un típico esquema pseudoarquitectónico mediante la colocación de pilastras en las esquinas, de las que pendería una gran guirnalda, al menos en el lado frontal ${ }^{64}$.

\footnotetext{
${ }^{63}$ Beltrán Fortes, Ordóñez Agulla, 2004.

${ }^{64}$ Nos parece que estaría más en consonancia con el diseño más simple de la primera de las hipótesis de su editora (supra fig. 14). Paralelos para esa disposición de una gran guirnalda que pende de pilastras en las esquinas y ocuparía el frente del cuerpo inferior del mausoleo lo tenemos en varios monumentos sepulcrales hispanos: así, en el de Sofuentes (Zaragoza) (según Fatás, Martín-Bueno, 1977: 204ss.; Beltrán Fortes, Baena del Alcázar, 1996: 126), aunque en este caso la ornamentación es mucho más rica, ya que la guirnalda se sitúa sobre un motivo de celosía y los espacios libres se decoran con máscaras y —en la comba - relieves de armas; es muy posible que tuviera asimismo un friso dórico, aunque desconocemos cómo se coronaba el segundo cuerpo (¿sería posible que asimismo fuera con pulvinos?). También en otro
}

También un diseño con pilastras en las esquinas se documentaría, de forma hipotética, en los casos de Graccurris, puesto que el edificio restituido correspondería en realidad al mausoleo, y de Segobriga, ambos ya citados.

En ese marco se situaba nuestra restitución de 1990 (Beltrán Fortes, 1990: 202ss., figs. 13-14) (supra figs. 42-43), en que proponíamos hipotéticamente como decoración del cuerpo inferior un esquema de pilastras de las que colgaban guirnaldas y entre las que se situaban erotes alados, siguiendo modelos bien documentados en los territorios del Alto Guadalquivir (Beltrán Fortes, Baena del Alcázar, 1996: 103ss.), y sobre los que no vamos a entrar ahora. Ya indiqué, en un primer momento, a propósito de tales basamentos con tan rica decoración en relieve «...la posibilidad de que tales monumentos de opus quadratum se coronasen con un segundo cuerpo arquitectónico (con naiskos), quizá más en consonancia con la presencia de las pilastras...», en una línea que he desarrollado con posterioridad (Beltrán Fortes, 2002a: 243 ss.; Baena del Alcázar, Beltrán Fortes, 2002: 60 s.) ${ }^{65}$, por lo que es más probable que esos fragmentos hubieran formado parte de edificaciones sepulcrales de carácter turriforme y de varios pisos; aunque tampoco se puede afirmar de forma taxativa que ninguno de los monumenta surpeninsulares en forma de altar no tuviera ornamentación relivaria. Así lo indicaba de forma exacta $\mathrm{H}$. von Hesberg al decir que esos fragmentos de la campiña giennense «...gehörten offenbar vorwiegend zu mehrsctöckigen Aediculabauten und einzelen vielleicht auch zu Altären» (von Hesberg, 1993: 162). De la excepcionalidad que llegaron a alcanzar algunos ejemplares da buena prueba el mausoleo norteafricano de época augustea de C. Iulius Felix en Henchir Messaouer, con friso dórico, pilastras y metopas decoradas con signos zodiacales (Ferchiou, 1987) (fig. 47).

Otra cuestión discutible se refiere al desarrollo exacto del coronamiento. Hemos visto que existen dos tipos fundamentales de pulvinos - cilíndricos y con alargamientos laterales de diversas variantes-, que asimismo se testimonian en los territorios hispanos. De forma usual en los territorios itálicos y bue-

monumento de Numancia, según Gutiérrez Behemerid, 1993: 155ss.; cfr. Beltrán Fortes, Baena del Alcázar, 1996: 152s.

${ }^{65}$ Este tipo de monumento funerario con decoración de pilastras, guirnaldas y erotes en el cuerpo inferior asimismo se documenta en la colonia Patricia a partir de dos interesantes fragmentos de bloques calizos que habían sido reutilizados en una tumba del siglo IV d.C. (Márquez Moreno, 1998: 198, lám. 60; y 2002: 225s., lám. 3) y para los que se ha indicado una similar disposición en varios cuerpos (Vaquerizo Gil, 2001: 149s., fig. 12; y 2002b: 189ss., figs. 23-24). 


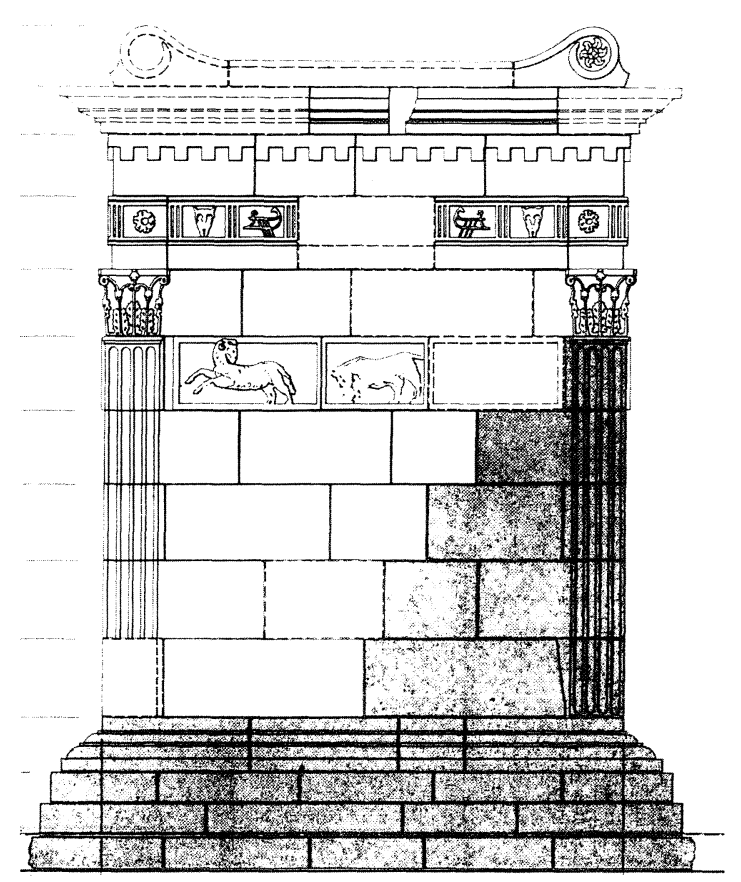

Fig. 47. Restitución del frente del mausoleo augusteo de $C$. Iulius Felix en Henchir Messaouer, según Ferchiou, 1987, fig. 3 .

na parte de las provincias occidentales los pulvinos se colocaban en el coronamiento sin ningún elemento intermedio a manera de frontón, como se ha propuesto también para la mayor parte de las restituciones hispanas. También se testimonian ejemplares que sí sitúan un frontón entre los pulvinos, siguiendo el esquema que se hará tradicional asimismo en la producción de arae ${ }^{66}$, como ocurre raramente en Italia, pero sobre todo en ciertas regiones, como la serie gala de Neumagen, con un pequeño frontón triangular que no sobrepasa la altura de los pulvinos ${ }^{67}$ (von Massow, 1932; con las correcciones cronológicas en Beltrán Fortes, 1991b). A nadie escapa que una de las restituciones llevadas a cabo en los mausoleos en forma de altar del Museo Arqueológico de Barcelona (supra fig. 5), precisamente aquella que utilizaba los pulvinos con alargamientos laterales, también disponía un elemento intermedio, de perfil superior curvo, que se unía a los extremos

${ }^{66}$ Para las producciones de arae, Di Stefano Manzella, 1987: 84ss.; Boschung, 1987. Si bien en ciertos talleres hispanos, como los béticos, su producción se estandariza siguiendo los modelos romanos sólo durante el siglo II d.C. (según Stylow, 1995: 225).

${ }_{67}$ Ya llamamos la atención que en ciertas arae y coronamientos de cartelas de cupae de Barcino entre los pulvinos con alargamientos laterales se situaban frontones triangulares que tampoco sobrepasaban la altura de los pulvinos (Beltrán Fortes, 1990: 197, figs. 6-7).

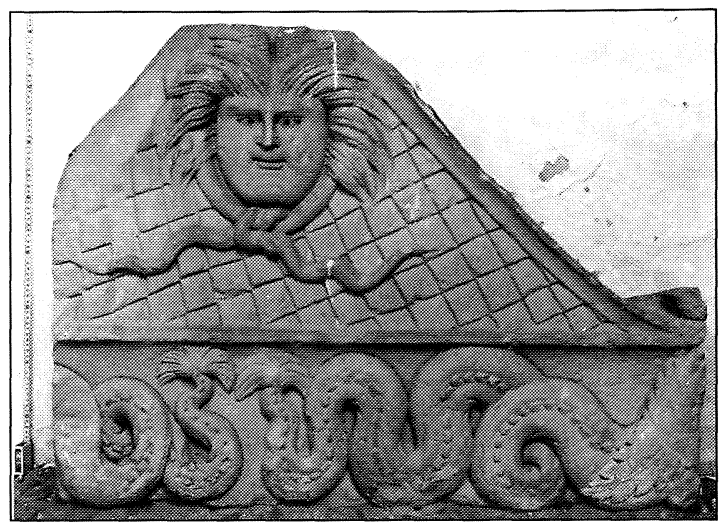

Fig. 48. Frontón con gorgoneion y friso de thiasos marino de Iliturgi (Mengíbar, Jaén). Colección La Chica, de Mengíbar. Foto: Instituto Arqueológico Alemán de Madrid (P. Witte).

interiores de los citados alargamientos, conformando realmente un frontón. Aunque ha sido mantenida esa hipótesis como válida con posterioridad (Gamer, 1989: 125; von Hesberg, 1993: 162, fig. 80b), en realidad no se conserva - que sepamos ${ }^{68}$ - ningún elemento que sustente esa restitución, ni aún en todo el conjunto de piezas de la serie catalana se conocen elementos que pudieran haber cumplido una función de frontón; aunque esa ausencia de constatación no hace válida per se la solución contraria.

En el esquema reconstructivo que llevé a cabo en 1990 para los ejemplares andaluces recogí la posibilidad de que pudiera haber existido un elemento de frontón entre los pulvinos y así aparece en el dibujo reconstructivo, asociado a pulvinos con alargamientos laterales (Beltrán Fortes, 1990: 216 ss., n $^{\text {os }}$ 9-10, figs. 19-20) (supra fig. 42). Con esa licencia utilicé diversos fragmentos de procedencia diversa, como un frontón de Iliturgi con gorgoneion y un friso marino por debajo (fig. 48), pero sólo como hipótesis ${ }^{69}$ y tras hacer un análisis amplio de la cuestión y concluir que este tipo de frontones béticos asimismo pudieron haber sido coronamientos de edículas o incluso de grandes estelas pseudoarquitectónicas (Beltrán Fortes, 1990: esp. 199-202). Esa restitución

\footnotetext{
${ }^{68}$ Hemos constatado simplemente de uisu la existencia de bloques triangulares, que parecen lisos y elaborados en cali$\mathrm{za}$, dentro de los mismos rellenos de la torre bajo la c/ Tapicería (actualmente en el área expositiva del Museo de Historia de la Ciudad de Barcelona), cuyas dimensiones podrían ser válidas para elementos de frontón, pero es simplemente una posibilidad.

69 Se decía: «Puesto que todas las piezas estudiadas proceden de hallazgos casuales, no puede afirmarse tajantemente que pulvinos y frontones formasen parte de un mismo tipo de mausoleo; y debe aceptarse además que otras tumbas sólo se coronaran con pulvinos...» (Beltrán Fortes, 1990: 201).
} 


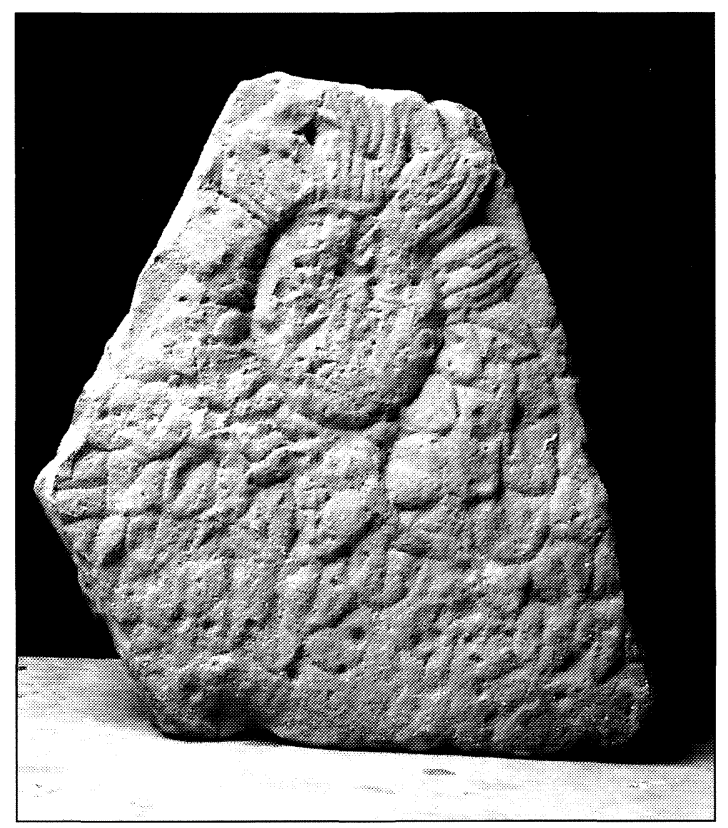

Fig. 49. Frontón con gorgoneion de Castulo (Cazlona, Linares, Jaén), conservado en el Museo Arqueológico de Linares.

concreta ha sido criticada con posterioridad, aunque tampoco la solución es fácil. Así, en relación con los frontones de Iliturgi que utilizamos en nuestra restitución ${ }^{70}$, von Hesberg ha mantenido que podrían tratarse más bien de coronamientos de pequeñas edículas (von Hesberg, 1993: 167); D. Boschung (1993: 539ss.) ha apuntado que podrían corresponder asimismo a parapetos laterales de grandes altares, mientras que C. Weiss (2000: 284s.) se decide porque hubieran sido frontones de fachadas de tumbas del siglo II d.C. Dentro de esas diversas posibilidades en el caso de los frontones de Iliturgi y de otros que se incluyen bajo esa tipología (de base ancha y perfiles cóncavos), asimismo me he inclinado posteriormente porque, en efecto, debieron haber correspondido a coronamientos de edículas (Beltrán Fortes, Baena del Alcázar, 1996: 129ss.; Baena del Alcázar, Beltrán Fortes, 2002: 54s.), en las que se imitaría el coronamiento de los altares ${ }^{71}$. Por el con-

${ }^{70}$ G. Gamer (1981: 82) interpretaba erróneamente uno de ellos como parte de un coronamiento piramidal de perfil cóncavo de un mausoleo de varios pisos, según expusimos en Beltrán Fortes, Baena del Alcázar, 1996: 136.

${ }^{71}$ Tampoco queda claro, por ejemplo, el tipo de monumento que coronó el frontón sepulcral de Corduba que lleva los epitafios de varios libertos de la gens Cacia, fechado en época de Claudio, que, amén de un retrato funerario que decora el centro del frontón, presenta dos elementos pulvinares en los laterales, pero en una curiosa disposición, adosados a la parte alta de ambos laterales del frontón (CIL II ${ }^{2} / 7,428$; Stylow, 1995: 224, fig. 14; Vaquerizo Gil, 2002b: 188, nota trario, no debe olvidarse que asimismo conocemos otros tipos de frontones decorados con el gorgoneion en su frente que o bien disponen lo que habíamos denominado como «acroteras rectangulares» (Beltrán Fortes, 1990: 220 ss., $\mathrm{n}^{\text {os }} 16-18$ ) o bien presentan una base más estrecha y lados rectos, como ocurre en sendos ejemplares de Arua (Alcolea del Río, Sevilla) y Castulo (fig. 49) (Beltrán Fortes, 1990: $219, \mathrm{n}^{\text {os }}$ 14-15). Podría pensarse en este último caso la posibilidad de que se situaran en el centro de un mausoleo con pulvinos.

Un testimonio excepcional que documenta fehacientemente la asociación de típicos pulvinos cilíndricos con un frontón lo tenemos en el coronamiento monolítico de Castulo, a pesar de la fractura (supra fig. 34). El frente del frontón se constituye a partir del alargamiento de los extremos de los pulvinos y se contraponen con volutas en la parte superior, ocupando el centro la cabeza de una figura barbada y con cuernos - quizás Pan-, pero a pesar de todo constituye efectivamente un frontón. El único inconveniente lo constituye las pequeñas dimensiones del coronamiento, ya que a pesar de que los pulvinos tienen algo más $0,35 \mathrm{~m}$ de diámetro el frente sólo tiene $0,93 \mathrm{~m}$ de anchura. También de pequeñas dimensiones son los coronamientos monolíticos de la zona de Valencia, que vimos supra, en los que asimismo se disponen frontones entre los pulvinos y que en estos casos podían vincularse una datación más tardía durante el siglo II d.C. En todo caso no corresponden a grandes mausoleos en los que el cuerpo del altar constituya la cámara sepulcral propiamente dicha.

Esa misma solución de colocar un frontón entre los pulvinos la testimonia ahora el significativo monumentum de Las Eras de Ontur (supra fig. 46), pero donde el frontón intermedio decorado con el gorgoneion adquiere una altura mucho mayor, superando la línea de los pulvinos y documentando, pues, otra variante en los tipos de coronamiento. Como matizan adecuadamente los editores: «En principio, estos frontones constituyen el remate de monumentos funerarios turriformes o de podio, aunque el hecho de que en el caso de Ontur aparezca junto a un cornu decorado con el mismo tipo de escamas, que debe corresponder al mismo edificio, nos obliga a pensar que pudo tratarse de un monumento en forma de altar» (Abad Casal, Abascal Palazón, San Gamo, 2002: 274).

88, fig. 19). La pieza, elaborada en caliza micrítica, mide $0,98 \mathrm{~m} \times 1,25 \mathrm{~m} \times 0,46 \mathrm{~m}$, y el epígrafe indica que correspondía a una tumba no unipersonal, pero que sólo correspondería a dos difuntos (los libertos Cn. Cacius Cn. C. l. Firmo y Cn. Cacius Cn. l. Vrsus), y construye el conliberto Cn. Cacius Cn. l. Quietus. Cfr. además, Stylow, 2002: 357 y nota 24. 
Al hilo de todo lo dicho, hemos de concluir que los monumenta hispanos en forma de altar pudieron o no disponer frontones entre los pulvinos del coronamiento, dentro de las frecuentes variantes que documenta la arquitectura romana de carácter sepulcral en los períodos tardorrepublicano y altoimperial. Por último, debemos mencionar la singularidad de otra de las propuestas realizadas, en relación a la restitución de los mausoleos a los que pertenecieron los pulvinos graníticos de Augusta Emerita. Nosotros habíamos llevado a cabo una solución sin frontón y, como es habitual, con los pulvinos separados entre sí (Beltrán Fortes, Baena del Alcázar, 1996a: 108, fig. 2) (supra fig. 40), pero T. Nogales propone que los pulvinos se unían entre sí sin solución de continuidad en los extremos correspondientes de los alargamientos laterales, conformando diversas posibilidades, según la forma de éstos; e incluso que podrían unirse cuatro piezas pulvinares, quedando en la parte superior «... una cavidad central que bien pudiera estar practicada a efectos de permitir desde el coronamiento superior el acceso al espacio donde se custodiarían las urnas cinerarias...» (en Nogales Basarrate, Márquez Pérez, 2002: 126 y fig. 3, a-c) (supra fig. 45). La hipótesis es atractiva y para su autora resolvería de forma simple el problema de la disposición de los pulvinos, con soluciones que podrían tener similitudes formales con otros coronamientos de altares ${ }^{72}$, estando las dimensiones finales de los mausoleos dentro de los parámetros plausibles ${ }^{73}$.

Para finalizar este apartado debemos hacer referencia a dos pulvinos que introducen variantes en los modelos más o menos establecidos (cilíndricos o con alargamientos laterales), siendo los dos únicos ejemplares andaluces que se elaboraron en mármol. En primer lugar, el pulvino de Tucci, con su inusual alargamiento lateral, en que se grabó una especie de cartela moldurada de forma rectangular. En segundo lugar, el de Italica, en que el pulvino se elabora sólo parcialmente en el bloque original, que queda liso en su mayor parte, sirviendo como elemento de cubrición del monumentum, aunque desconocemos la forma exacta de éste; se trata de un tipo de corona-

${ }^{72}$ Por ejemplo, el espacio recto situado entre los pulvinos en el primer caso se asemeja, p.e., al coronamiento del mausoleo norteafricano de $C$. Iulius Felix de Henchir Massaouer (supra fig. 41); además, la unión de los pulvinos con el alargamiento de perfil cóncavo ofrece en realidad un frontón entre los pulvinos.

${ }^{73}$ En el primer caso el frente mediría 2,36m (y sería el mayor en función de los pulvinos conservados); en el segundo caso, $1,82 \mathrm{~m}$. No obstante, el coronamiento monolítico de Castulo, que mencionaremos luego, sólo mide en su frente $0,93 \mathrm{~m}$. miento que asimismo se da entre los altares de pequeño formato de la Bética, datados en general durante el siglo II d.C. (Stylow, 1995: 225) ${ }^{74}$.

\section{DISTRIBUCIÓN TERRITORIAL EN HISPANIA}

La distribución territorial en Hispania de los monumenta en forma de altar ofrece hoy día un panorama bastante diverso del que teníamos hace sólo pocos decenios (supra fig. 3). De hecho se ha convertido en un tipo sepulcral que, en sus diversas variantes, tuvo un uso constatado en amplias zonas de la Hispania altoimperial. También ese panorama ha cambiado de forma paralela a la propia consideración del fenómeno general que podríamos denominar como de «romanización» del mundo funerario hispanorromano, según queda de reflejo, por ejemplo, en los resultados del último Congreso dedicado al tema donde se analiza de forma especial el panorama peninsular (AA.VV., 2002).

Sin poder establecer una efectiva discriminación con base en la cronología de las diversas piezas, que ya hemos visto que es un extremo difícil de establecer de forma concreta en la mayoría de los casos, puede establecerse la conclusión evidente de que las áreas geográficas hispanas en las que se constata la presencia del mausoleo en forma de altar con pulvinos coincide básicamente con los ámbitos territoriales en los que se había documentado otros tipos de monumenta sepulcrales con base en una arquitectura funeraria desarrollada, como los tipos turriformes, en forma de templo, recintos, etc., según queda de manifiesto si comparamos su dispersión con los mapas generales elaborados por M. L. Cancela (1993: 255) y por H. von Hesberg (1993: 179, fig. 87). Sin embargo, pueden verse varias concentraciones, más o menos amplias e intensas según los casos, aunque también podrían estar derivadas sólo de ausencias en la investigación. En primer lugar, cabe destacar el temprano e intenso uso que tuvo en la actual costa catalana - concentrado en Tarraco y Barcino - y la importante línea de penetración que supuso el valle del Ebro, con testimonios en Zaragoza y Teruel, que llegan hasta Navarra y La Rioja. El segundo gran área donde se testimonia el tipo con más profusión es la Baetica, ya que ahora no sólo

\footnotetext{
${ }^{74}$ No es un argumento determinante, ya que - como constatara von Hesberg (1996: 160) - en la colonia Patricia el uso del mármol en la arquitectura funeraria se daría ya en momentos tempranos del siglo I d.C. Es cierto que se trata de la capital de la Baetica, pero asimismo Italica fue una ciudad con importantes influencias foráneas y temprana marmolización.
} 
conocemos el importante conjunto del alto Guadalquivir (que sigue siendo el más importante), sino también en otros ámbitos del bajo y medio Guadalquivir, incorporando ya el significativo punto de la capital provincial, y del valle del Genil y la depresión de Antequera, con el añadido que supone - pero dentro ya del conuentus Carthaginensis- el ejemplar almeriense de Vélez-Rubio.

En el resto del territorio hispano destacarían a continuación dos ámbitos más localizados. En primer lugar, el conjunto lusitano constituido por los dos importantes conjuntos de Mérida e Idanha (con los añadidos de Trujillo y Coria) y que en cierto modo se relaciona con el anterior bético a partir de ejemplares como los localizados en Esparragosa de la Serena o Belalcázar, de similar tipología a los lusitanos a pesar de estar ya en territorio bético y que también emplean el granito local de la zona. En segundo lugar, el foco más localizado de Segobriga, que con su singularidad tipológica constituye el único punto conocido en la Meseta, al menos por ahora. Finalmente, en la costa levantina ${ }^{75}$, frente a la constatación ya durante el siglo I a.C. de otros tipos de monumenta del siglo I a.C., como el monumento de friso dórico de Sagunto (Almagro Gorbea, 1980), el tipo en forma de altar sólo se documenta más tardíamente y con testimonios diferenciados desde el punto de vista formal, como demuestra el recargado mausoleo de mediados del siglo I d.C. de Requena o los de dimensiones reducidas de Valencia y otras localidades costeras del siglo II d.C. de los que sólo se conoce el coronamiento monolítico, cuando se han impuesto además desarrollados monumentos turriformes, como los de Daimuz o Villajoyosa (Abad Casal, Bendala Galán, 1985). Diverso es el panorama del SE, donde junto a ejemplos tan señeros como «la Torre Ciega» de Cartagena (Abad Casal, 1989), los nuevos materiales de zonas más interiores de la actual provincia de Albacete ilustran un panorama mucho más rico y desconocido hasta ahora, que apunta a una temprana introducción de esquemas arquitectónicos sepulcrales en la zona, vinculados -al menos tipológicamente- a los de las regiones del alto Guadalquivir (Abad Casal, Abascal Palazón, Sanz Gamo, 2002).

Debemos concluir que en Hispania el monumentum en forma de altar con pulvinos -en sus diversas variantes- constituyó un tipo más dentro de esa panoplia de modelos de la arquitectura funeraria originados en la Península Itálica que, desde fines de la época republicana y los comienzos de la época im-

\footnotetext{
75 A nivel general sobre el panorama funerario de esta
} zona puede verse ahora González Villaescusa, 2001. perial, fue adaptándose en esas zonas citadas de los territorios hispanorromanos, en lo que debió ser un claro factor de romanización. En efecto, no se puede seguir manteniendo que los denominados mausoleos turriformes hispanorromanos se articularon en una doble órbita de influencia, en la que la zona mediterránea de la Tarraconensis y el valle del Ebro se desarrollaba exclusivamente con base en las relaciones e influencias francesas y la Baetica con las norteafricanas (cfr. también Rossetti, 1999: 231ss.). También en contra de otra hipótesis que establecía una línea continuada de adopción de esos modelos de la arquitectura funeraria desde la Península Itálica hasta el sur hispano, pasando de forma sucesiva por el sur de Francia, Cataluña y el Sureste peninsular, ya se posicionó de forma clarividente A. Balil Illana (1979) indicando que debieron existir durante el s. I a.C. complejas y diversas relaciones multidireccionales que desde la Península Itálica u otras zonas (como la Narbonense) afectarían a esos territorios hispanos citados de forma coetánea o, en todo caso, sin tener que responder a ese esquema de progresión desde el NE al Sur ${ }^{76}$. Este planteamiento, que nos parece el adecuado (p.e., Beltrán Fortes, 1997: 125), se explicaría en función del propio proceso de romanización peninsular y los importantes cambios que se producen en la sociedad hispanorromana durante el siglo I d.C., especialmente con las consecuencias de la nueva política de colonización/ municipalización de época de César y Augusto y el auge de la emigración itálica, que tiene un importante reflejo, por ejemplo, en las ciudades del alto Guadalquivir (Beltrán Fortes, Baena del Alcázar, 1996: esp. 169 ss.). En coincidencia con una nueva y significativa presencia de población romano-itálica (en ocasiones de origen militar, especialmente mediante deductiones coloniales) se desarrollaría ese proceso de desarrollo de la arquitectura funeraria según los principales modelos itálicos del siglo I a.C., ya que tampoco podemos olvidar que en su mayoría corresponden a necrópolis urbanas. Pocos datos tenemos para poder reconstruir exactamente cuál fue el tipo de clientela que favoreció ese proceso en Hispania. En la Península Itálica se ha destacado la importancia que la colonización militar del siglo I a.C. tuvo en la expansión de estos tipos de monumenta, como en los caracterizados por el friso dórico en el área centroitálica, donde se había producido un importante desarrollo durante la centuria anterior de la llamada «cultura ellenistica 'italica'» (Torelli, 1968),

\footnotetext{
${ }^{76}$ «...la difusión desde los centros itálicos debió ser radical y simultánea, no costera e itinerante. Posiblemente más precoz, o coetánea, en la Citerior que en la Narbonense...» (Balil Illana, 1979: 64).
} 
y en cuya clientela no sólo se destacaban miembros de las aristocracias municipales, sino la asimismo denominada «burguesía» itálica en la que los libertos enriquecidos adquieren una enorme pujanza ${ }^{77}$, como asimismo se demuestra en Roma.

Por el contrario $\mathrm{H}$. von Hesberg destacó que en la Península Ibérica no tuvo una correlación estricta el mundo funerario tan desarrollado arquitectónicamente y de claro carácter autorrepresentativo en ciertas zonas de Italia en momentos tardorrepublicano y altoimperial, faltando en general las típicas uiae sepulcrales en las necrópolis urbanas hispanorromanas (von Hesberg, 1993: 176ss.; cfr. las consideraciones de Rossetti, 1999: 254), al menos a la luz actual de la incompleta documentación. Podemos afirmar que en Hispania el proceso de «romanización del mundo funerario» (cfr. Ghedini, 1984), en el que se incluirían los monumenta en forma de altar con pulvinos, sería iniciado por representantes de la nueva oligarquía ciudadana conformada a fines del período republicano en la que, junto a los nuevos colonos y otros emigrantes romano-itálicos, se fueron integrando de forma progresiva miembros conspicuos de los antiguos elementos indígenas. Los escasos ejemplos de la epigrafía que se pueden vincular a esa arquitectura funeraria en algún caso - pero no estrictamente a mausoleos en forma de altar- lo testimonian; así, el matrimonio de Stlaccii de Salaria bien pudieron ser de los primeros colonos de la colonia y, por el contrario, el duoviro $\mathrm{M}$. Horatius Bodonilur, de Vrgauo, denotaba en su cognomen sus raíces indígenas, en un proceso de asimilación que se puede reconstruir mucho mejor en el caso de la serie de epígrafes (con nombres indígenas, en proceso de asimilación y ya plenamente romanos) de las urnas sepulcrales de la llamada «tumba de los Pompeyos» ${ }^{78}$, en Torreparedones (Córdoba), que debe corresponder asimismo a una ciudad privilegiada en el siglo I a.C., Ituci (CIL II ${ }^{2}$ / 5: n ${ }^{\text {os }}$ 409-420; Beltrán Fortes, 2000b).

\section{BIBLIOGRAFÍA CITADA}

AA.VV., 1983: Les «Bourgeoisies» municipales italiennes aux $I^{e}$ et $I^{e r}$ siècles av. J.C., Paris-Naples.

77 Vid., en general, AA.VV., 1983. Estudios más concretos referidos al ámbito funerario y su correlación social, cfr., por ejemplo, para el norte de la Península Itálica, Ghedini, 1984 y, especialmente, Compostella, 1996 (Véneto) o AA.VV., 1997 (Aquileia y la Cisalpina).

${ }^{78}$ Preparamos ahora junto a P. Rodríguez Oliva y J. Maier Allende una revisión historiográfica y arqueológica de este importante monumento sepulcral y de sus ajuares.
AA.VV., 1987: Römische Gräberstrassen. Selbsdarstellung - Status - Standard (VON HESBERG, H.; ZANKER, P., eds.), München.

AA.VV., 1997: Monumenti sepolcrali romani in Aquileia e nella Cisalpina, Trieste.

AA.VV., 2001: Funus Cordobensium (VAQUERIZO GIL, D., ed.), Córdoba.

AA.VV., 2002: Espacios y usos funerarios en el Occidente Romano (VAQUERIZO GIL, D., ed.), Córdoba.

ABAD CASAL, L., «La Torre Ciega de Cartagena (Murcia)», Homenaje al Profesor Antonio Blanco Freijeiro, Madrid, 243-266.

ABAD CASAL, L.; BENDALA GALÁN, M., 1988: «Las torres funerarias de Daimuz y Villajoyosa: dos monumentos romanos olvidados», Lucentum, IV, 1985, 147-184.

ABAD CASAL, L.; GUTIÉRREZ LLORET, S.; SANZ GAMO, R., 1998: El Tolmo de Minateda. Una historia de 3500 años, Toledo.

ABAD CASAL, L.; ABASCAL PALAZÓN, J. M.; SANZ GAMO, R., 2002: «Monumentos funerarios romanos de época romana en la provincia de Albacete», Segundo Congreso de Historia de Albacete. I. Arqueología y Prehistoria, Albacete, 271-282.

ABASCAL PALAZÓN, J. M.; RAMALLO ASENCIO, S. F., 1997: La ciudad de Carthago Nova: la documentación epigráfica, Murcia.

ABÁSOLO, J. A.; MARCO, S., 1995: «Tipología de las estelas de la mitad septentrional de la Península Ibérica», Roma y el nacimiento de la cultura epigráfica en Occidente (BELTRÁN LLORÍS, F., ed.), Zaragoza, 327-359.

ALBERTINI, E., 1911-1912: «Sculptures antiques $\mathrm{du}$ Conventus Tarraconensis», Anuari de l'Institut d'Estudis Catalans, IV, 323-474.

ALMAGRO BASCH, M., 1978: Segobriga. Guía del conjunto arqueológico, Madrid.

ALMAGRO-GORBEA, M., 1980: «El monumento funerario romano con friso dórico de Sagunto», Saguntum, 15, 127-135.

ALMAGRO-GORBEA, M.; ABASCAL PALAZÓN, J. M., 1999: Segobriga y su conjunto arqueológico, Madrid.

ALMEIDA, F. de, 1956: Egitânia. História e Arqueologia, Lisboa.

- 1977: «Civitas Igaeditanorum et Egitania. Municipium romain-ville épiscopale wisigothique», Thèmes de recherches sur les villes antiques d'Occident, Paris, 39ss.

ANÓNIMO, 1965 : «Arqueología castulonense», Oretania, 7, 21, 159.

ARANEGUI GASCÓ, C., 1995: «Los monumentos 
funerarios romanos descubiertos en Edeta (Lliria, Valencia)», Saguntum 29 (= Homenatge a Milagro Gil-Mascarell), I, 197-210.

ARASA I GIL, F., 1987: «El monumento romano de la ermita de la Virgen del Cil (La Iglesuela del Cid, Teruel», Boletín del Museo de Zaragoza, 6, 141-179.

- 2000: «Esculturas romanas de la provincia de Castellón», Actas de la III Reunión sobre Escultura Romana en Hispania (LEÓN ALONSO, P.; NOGALES BASARRATE, T., coords.), Madrid, 149-172.

BAENA DEL ALCÁZAR, L., 1993: «Monumentos funerarios romanos de Segóbriga», Estudios dedicados a Alberto Balil. In memoriam, Málaga, 147-161.

BAENA DEL ALCÁZAR, L.; BELTRÁN FORTES, J., 2002: Las Esculturas Romanas de la Provincia de Jaén. Corpus Signorum Imperii Romani. España. 1.2, Murcia.

BALIL ILLANA, A., 1958: «Dos frisos arquitectónicos del Museo Arqueológico de Barcelona», $R A B M, 64,1$ ss.

- 1961: Las murallas romanas de Barcelona, Madrid.

- 1964: Colonia Iulia Augusta Paterna Faventia Barcino, Madrid.

- 1979: «Los gorgoneia de Barcino», Faventia, I, 1, 63-70.

- 1988: Esculturas Romanas de la Península Ibérica. VII y VIII (= Studia Archaeologica, no 76), Valladolid.

BARRIL VICENTE, M., 1993: «Colección Góngora», De Gabinete à Museo. Tres siglos de Historia. Madrid. Museo Arqueológico Nacional, Madrid, 338-340.

BELTRÁN FORTES, J., 1990: «Mausoleos romanos en forma de altar del sur de la Península Ibérica», AEspA, 63, 183-226.

- 1991a: Recensión del libro de GAMER, G. 1989: Formen römischer Altäre auf der Hispanischen Halbinsel, Mainz am Rhein, AEspA, 64, 369-371.

- 1991b: «El mausoleo londinense del procurator Iulius Classicianus», Habis, 22, 177-189.

- 1997: «Monumenti funerari», Hispania Romana. Da terra di conquista a provincia dell'Impero (ARCE, J.; ENSOLI, S.; LA ROCCA, E., eds.), Milano, 119-125 (= «Monumentos funerarios», Hispania Romana. Desde tierra de conquista a provincia del Imperio, Zaragoza, 1998, 119125).

- 1999: «Las Cabezas de San Juan (Sevilla): De Vgia a Conobaria», Habis, 30, 283-295.
- 2000a: «Leones de piedra romanos de Las Cabezas de San Juan (Sevilla). A propósito de un nuevo ejemplar identificado», Spal, 9 (= Homenaje al profesor Enrique Vallespî), 435-450.

- 2000b: «Mausoleos romanos de Torreparedones (Castro del Río / Baena, Córdoba): sobre la «Tumba de los Pompeyos» y otro posible sepulcro monumental», Habis, 31, 113-136.

- 2002a: «La arquitectura funeraria en la Hispania meridional durante los siglos II a.C. - I d.C.», Espacios y usos funerarios en el Occidente Romano (VAQUERIZO GIL, D., ed.), Córdoba, I, 233-258.

- 2002b: «Esculturas romanas desaparecidas de la provincia de Jaén, a partir del Catálogo de los Monumentos Históricos y Artísticos de E. Romero de Torres», Habis, 33, 459-486.

- 2002c: «Descubrimientos arqueológicos en el Anfiteatro de Italica en 1914», Spal, 11 (= Homenaje al profesor Manuel Pellicer), 365-376.

BELTRÁN FORTES, J.; BAENA DEL ALCÁZAR, L., 1996a: «Pulvinos monumentales de Mérida», Anas, 9, 105-131.

- 1996b: Arquitectura funeraria romana de la colonia Salaria (Úbeda, Jaén). Ensayo de sistematización de los monumenta funerarios altoimperiales del alto Guadalquivir, Sevilla.

- 2002: «Materiales y técnicas escultóricas en las ciudades romanas del Alto Guadalquivir», Cuadernos Emeritenses, 20, 193-214.

BELTRÁN FORTES, J.; ORDÓÑEZ AGULLA, S., 2004: «Un friso dórico funerario de El Guijo (Écija, Sevilla)», Habis, 35, 233-255.

BLÁZQUEZ, J.M.; CONTRERAS, R.; URRUELA, J.J., 1984, Castulo IV, Excavaciones Arqueológicas en España $n^{\circ} 131$, Madrid.

BLECH, M., 1993: en Hispania Antiqua. Denkmäler der Römerzeit, Mainz am Rhein, 334s., láms. $118 \mathrm{~s}$.

BOSCH DE DORIA, M., 1998: «La Gorgona de Mataró. Un altar funerari monumental a la Via Augusta dins el territori d'Iluro», Laietania, 11, 127-141.

BOSCHUNG, D., 1987: Antike Grabaltäre aus den Nekropolen Roms, Bern.

- 1993: Recensión del libro de GAMER, G., Formen römischer Altäre auf der Hispanischen Halbinsel, Mainz am Rhein, 1988, BJb, 193, 539548.

CABALLOS RUFINO, A., 1994: Itálica y los italicenses, Sevilla.

CABALLOS RUFINO, A.; MARÍN FATUARTE, J.; RODRÍGUEZ HIDALGO, J. M., 1999: Italica Arqueológica, Sevilla. 
CANCELA RAMÍREZ DE ARELLANO, M. L., 1991: Construcciones funerarias romanas en Hispania: tipología, Zaragoza (Tesis Doctoral inédita).

- 1993: «Elementos decorativos de la arquitectura funeraria», Actas de la I Reunión sobre Escultura Romana en Hispania (NOGALES BASARRATE, T., ed.), Madrid, 239-262.

- 2002: «Aspectos monumentales del mundo funerario hispano», Espacios y usos funerarios en el Occidente Romano (VAQUERIZO GIL, D., ed.), Córdoba, I, 163-180.

CARMONA, S.; MORENO, M. F; BERMÚDEZ, J. M., 1997: Informe de la intervención arqueológica de urgencia en la $c /$ Adarve, $n^{\circ} 2$, inédito (depositado en la Delegación Provincial de Cultura de Córdoba).

CEBRIÁN FERNÁNDEZ, R., 2002: Comisión de Antigüedades de la Real Academia de la Historia. Antigüedad e inscripciones. 1748-1845. Catálogo e índices, Madrid.

COMPOSTELlA, C., 1995: Ornata Sepulcra. Le «borghesie» municipali e la memoria di sé nell'arte funeraria del Veneto romano, Firenze.

DI STEFANO MANZELLA, I., 1987: Mestiere di epigrafista. Guida alla schedatura del materiale epigrafico lapideo, Roma.

EISNER, M., 1987: Zur Typologie der Grabbauten im Suburbium Roms, 26 Ergh. RM, Mainz.

ESPINOSA, U., 1986: Epigrafía romana de La Rioja, Logroño.

- 1996: "Arquitectura funeraria de Vareia (Varea, Logroño): influencias mediterráneas», Homenaje al profesor Manuel Fernández-Miranda (=Complutum Extra, 6, I), Madrid, 433-440.

FATÁS, G.; MARTÍN-BUENO, M., 1977a: Epigrafía romana de Zaragoza y su provincia, Zaragoza.

FATÁS, G.; MARTÍN-BUENO, M., 1977: «Un mausoleo de época imperial en Sofuentes (Zaragoza)», $M M, 18,232-271$.

FERCHIOU, N., 1987: «Le Mausolée de C. Ivlivs Felix, à Henchir Messaover», $R M, 94,413$ ss.

GABELMANN, H., 1971: Römische Grabbauten in der frühen Kaiserzeit,

GAMER, G., 1981: «La torre de los Escipiones y otros monumentos funerarios sucesores del Mausoleo de Halicarnaso», BSAA, 47, 71ss.

- 1989: Formen römischer Altäre auf der Hispanischen Halbinsel, Mainz am Rhein.

GARCÍA Y BELLIDO, 1949: Esculturas Romanas de España y Portugal, Madrid.

GARCÍA Y BELLIDO, A.; MENÉNDEZ PIDAL, J., 1963: El distylo sepulcral romano de Iulipa (Zalamea), Madrid.
GHEDINI, F., 1984: «La romanizzazione attraverso il monumento funerario», Misurare la terra. Centuriazione e coloni nel mondo romano: il caso veneto, Modena, 52-71.

GIMENO PASCUAL, H.; STYLOW, A. U., 1994: Juan Pérez Holguín y la epigrafía trujillana, Anejos de Veleia, Serie Maior 8, Vitoria ( $=V e$ leia, 10, 1993, 117ss.).

GONZÁLEZ FERNÁNDEZ, J., 1996: Corpus de Inscripciones Latinas de Andalucía. II. Sevilla, III, Sevilla.

GONZÁLEZ PARRILLA, J. M., 2001: Las necrópolis romanas de Italica (Santiponce, Sevilla), Sevilla (memoria de licenciatura, inédita).

GONZÁLEZ ROMAN, C.; MANGAS MANJARRÉS, J., 1991: Corpus de Inscripciones Latinas de Andalucía. III. Jaén, I, Sevilla.

GONZÁLEZ VILLAESCUSA, R., 2001: El mundo funerario romano en el País Valenciano. Monumentos funerarios y sepulturas entre los siglos I a. de C.-VII d. de C., Madrid-Alicante.

GROS, P., 2001: L'architecture romaine du debut du III siècle av. J.C. à la fin du Haut-Empire. 2. Maisons, palais, villas et tombeaux, Paris.

GUTIÉRREZ BEHEMERID, M. A., 1990: «Frisos dóricos funerarios en la Península Ibérica: sistematización y cronología», $B S A A, 56,205$ ss.

- 1993: «El monumento funerario de Lucio Valerio Nepote de Numancia», BSAA, 59, 155-170.

HERNÁNDEZ VERA, J. A.; ARIÑO GIL, E.; MARTÍNEZ TORRECILLA, J. M.; NÚÑEZ MARCÉN, J., 1999: «La presa y el ninfeo del Sotillo (Alfaro, La Rioja): un conjunto monumental en la vía de Italia in Hispanias», Zephyrus, LII, 239-260.

IZQUIERDO PERAILE, I., 2000: Monumentos funerarios ibéricos: los pilares-estela, Valencia.

JIMÉNEZ DÍEZ, A., 2001: «La mirada pétrea: imágenes de la Gorgona en los monumentos funerarios hispanorromanos en forma de altar», Trabalhos de Antropologia e Etnologia, XLI (1-2), 179-194.

- 2002: «Necrópolis de época republicana en el Mediodía peninsular: «romanización» y sentimientos de identidad étnica», Espacios y usos funerarios en el Occidente Romano (VAQUERIZO GIL, D., ed.), Córdoba, I, 217-232.

JIMÉNEZ SALVADOR, J. L., 1995: «Un monumento funerario romano en forma de altar procedente de Valencia», Homenatge a Milagro Gil-Mascarell (= Saguntum, 29), Valencia, 211220.

- 2002: «Últimas novedades en relación al mundo funerario romano en el Este y Sureste de Hispa- 
nia (Siglos II a.C.-IV d.C.)», en VAQUERIZO GIL, D., ed., Espacios y usos funerarios en el Occidente Romano (VAQUERIZO GIL, D., ed.), Córdoba, I, 181-202.

JOULIA, J.-C., 1988: Les frises doriques de Narbonne, Bruxelles.

KOCKEL, V., 1983: Die Grabbauten vor dem Herkulaner Tor in Pompeji, Mainz.

LEÓN ALONSO, P., 1995: Esculturas de Italica, Sevilla.

LÓPEZ PAZ, P., 1993: «Observaciones sobre el concepto y el estatuto jurídico de las prefecturas. El ejemplo de Emerita Augusta», II Congreso Peninsular de Historia Antiga. Actas, Coimbra, 741 ss.

MANSUELLI, G. A., 1956: «Leoni funerari emiliani», $R M, 63,66 \mathrm{ss}$.

MARINI CALVINI, M., 1979: «Leoni funerari romani in Italia», Actas Xth. Int. Congress of Clasiccal Archaeology, London, 270ss.

- 1980: «Leoni funerari romani», Bolletino d'Arte, 7ss.

MÁRQUEZ MORENO, C., 1998: La decoración arquitectónica de la Colonia Patricia. Una aproximación a la arquitectura y urbanismo de la Córdoba romana, Córdoba.

- 2002: «La ornamentación arquitectónica en ámbito funerario de colonia Patricia», Espacios y usos funerarios en el Occidente Romano (VAQUERIZO GIL, D., ed.), Córdoba, II, 223246.

MARÍN-BUENO, M., 1976: «Nuevos núcleos romano-imperiales en el Ebro medio», Pyrenae, 12,149 ss.

MARTÍNEZ GARCÍA, J., «Elementos arquitectónicos de época visigoda en Vélez-Rubio», Revista Velezana, 5, 1986, 29-40.

MARTÍNEZ VALLE, A., 1991: «Una inscripción funeraria hallada en La Calerilla (Hortunas, Requena)», Saguntum, 24, 167-172.

- 1995: «El monumento funerario de La Calerilla de Hortunas (Requena, Valencia)», AEspA, 68, 259-281.

NOGALES BASARRATE, T.; MÁRQUEZ PÉREZ, J., 2002, «Espacios y tipos funerarios en Augusta Emerita», Espacios y usos funerarios en el Occidente Europeo (VAQUERIZO GIL, D., ed.), Córdoba, I, 113-144.

ORTALLI, J., 1978: «Un nuovo monumento funerario romano de Imola», Rivista di Archeologia, II, 58ss.

PAOLETTI, O., 1988: s.v. «Gorgones Romanae», LIMC, 345-362.

PÉREZ BAYER, F., 1998: Viajes Literarios (ed. preparada por MESTRE SANCHÍS, A.; PÉREZ, GARCÍA, P.; CATALÁ SANZ, J. A.), Valencia. PÉREZ LÓPEZ, I., 1992: Leones romanos en Hispania, Madrid.

PORTABELLA I BOSCH, M., 1997: «Els 'gorgoneia' del Museu d'Arqueologia de Catalunya», Miscel.lània Arqueològica (1996-1997), Barcelona, 153-163.

PUIG I CADAFALCH, J., 1934: L'arquitectura romana a Catalunya, Barcelona.

PUIG I CADAFALCH, J.; FALGUERA, A. DE; GODAY, J., 1908: L'Arquitectura romanica a Catalunya, Barcelona.

RODÁ DE LLANZA, I., 2000: «La escultura del sur de la Narbonense y del norte de Hispania Citerior: paralelos y contactos», Actas de la III Reunión sobre Escultura Romana en Hispania (LEÓN ALONSO, P.; NOGALES BASARRATE, T., coords.), Madrid, 173-196.

RODRÍGUEZ NEILA, J. F., 1992: «Algunas observaciones sobre los acotados funerarios romanos», Homenaje a J. Cabrera Moreno, Granada, 437-448.

ROMERO DE TORRES, E., 1914: Catálogo de los Monumentos Históricos y Artísticos de la provincia de Jaén, manuscrito inédito conservado en el CSIC, Madrid.

ROSSETTI, A.M., 1999: «Committenze e monumenti funerari nella Hispania Tarraconensis», Anales de Arqueología Cordobesa, 10, 231-262.

SÁNCHEZ ALBALÁ, J. I.; VINAGRE NEVADO, D., 1998: Corpus de inscripciones latinas de Coria, Coria.

SANMARTÍ, J., 1984: «Els edifics sepulcrals romans del païses catalans, Aragò i Murcia», Fonaments, 4.

SCHATTNER, T., dir., 1998: Archäologischer Wegweiser durch Portugal, Mainz.

SERRA VILLARÓ, J., 1928-1930: Excavaciones en la necrópolis romano-cristiana de Tarragona, Memorias de la Junta Superior de Excavaciones y Antigüedades, $\mathrm{n}^{\text {os }} 93,109$ y 111 , Madrid.

STYLOW, A. U., 1986: «Beiträge zur lateinischen Epigraphik im Norden der Provinz Córdoba. I. Solia», MM, 27.

- 1995: «Los inicios de la epigrafía latina en la Bética. El ejemplo de la epigrafía funeraria», Roma y el nacimiento de la cultura epigráfica en Occidente, BELTRÁN LLORÍS, F., ed., Zaragoza: $219-238$.

- 2002: «La epigrafía funeraria en la Bética», Espacios y usos funerarios en el Occidente Romano (VAQUERIZO GIL, D., ed.), Córdoba, I, 353-368 
TARACENA, B., 1947: «Arte Romano», Ars Hispaniae, II, Madrid.

TORELLI, M., 1968: «Monumenti romani con fregio dorico», Dialoghi di Archeologia, II/1, 32-54.

TOYNBEE, J. M. C.; WARD-PERKINS, J. B., 1950: «Peopled Scrolls. A Hellenistic Motif in Imperial Art», PBSR, 13, 1ss.

VAQUERIZO GIL, D., 2001a: «Formas arquitec-tónicas funerarias de carácter monumental en Colonia Patricia Corduba», AEspA, 74, 131-160.

- 2002a: «Recintos y acotados funerarios en Colonia Patricia Corduba», MM, 43, 168-206.

- 2002b: «Espacio y usos funerarios en Corduba», Espacios y usos funerarios en el Occidente Romano (VAQUERIZO GIL, D., ed.), Córdoba, II, 143-200.
VON HESBERG, H., 1992: Römische Grabbauten, Darmstadt.

- 1993: «Römische Grabbauten in den hispanischen Provinzen», Hispania Antiqua. Denkmäler der Römerzeit, Mainz am Rhein, 159-181.

- 1996: «La decorazione architettonica de Cordova. Sulla funzione dell'ornamentazione architettonica in una città romana», Colonia Patricia Corduba. Una reflexión arqueológica (LEÓN ALONSO, P., ed.), Córdoba, 155-174.

VON MASSOW, W., 1932: Die Grabmäler von Neumagen, Berlin-Leipzig.

WEISS, C., 2000: «Die Steindenkmäler der Sammlung 'de la Chica' in Mengíbar (Jaén) in Kontext der Sepulkralkunst des oberen Guadalquivirteiles», $M M, 41,253-317$. 